\title{
AVALIAÇÃO DA POSIÇÃO CONDILAR E DISFUNÇÃO TEMPOROMANDIBULAR EM PACIENTES COM MÁ OCLUSÃO DE CLASSE II SUBMETIDOS A PROTRUSÃO MANDIBULAR ORTOPÉDICA
}

\section{Ana Cláudia de Castro Ferreira Conti}

Dissertação apresentada à Faculdade de Odontologia de Bauru, da Universidade de São Paulo, como parte dos requisitos para obtenção do título de Doutor em Odontologia, área de Ortodontia.

(Edição Revisada) 


\section{AVALIAÇÃO DA POSIÇÃO CONDILAR E DISFUNÇÃO TEMPOROMANDIBULAR EM PACIENTES COM MÁ OCLUSÃO DE CLASSE II SUBMETIDOS A PROTRUSÃO MANDIBULAR ORTOPÉDICA}

\section{Ana Cláudia de Castro Ferreira Conti}

Dissertação apresentada à Faculdade de Odontologia de Bauru, da Universidade de São Paulo, como parte dos requisitos para obtenção do título de Doutor em Odontologia, área de Ortodontia.

(Edição Revisada)

Orientador: Prof. Dr. Marcos Roberto de Freitas 
Conti, Ana Cláudia Castro Ferreira

C767a Avaliação da posição condilar e disfunção temporomandibular em pacientes com má oclusão de Classe II submetidos a protrusão mandibular ortopédica / Ana Cláudia Ferreira Conti - Bauru, 2004 130p.: il;31cm.

Tese. (Doutorado) - Faculdade de Odontologia de Bauru. USP.

Orientador: Prof. Dr. Marcos Roberto de Freitas

Autorizo, exclusivamente para fins acadêmicos e científicos, a reprodução total ou parcial desta dissertação/tese, por processos fotocopiadpres e outros meios eletrônicos.

Assinatura:

Aprovado pelo Comitê de Ética da Faculdade de Odontologia de Bauru/USP, em reunião realizada em 15 de agosto de 2003. 


\section{ANA CLÁUDIA DE CASTRO FERREIRA CONTI}

03 de Outubro de 1970

Piquete - SP

1989-1992

1996-1997

$1998-2000$

1999

2001-2003

\author{
Nascimento
}

Curso de Graduação em Odontologia, na Faculdade de Odontologia de Bauru Universidade de São Paulo (FOB-USP)

Curso de Aperfeiçoamento em Ortodontia Preventiva e Interceptiva na PROFIS, Bauru.

Curso de Pós-graduação em Ortodontia, nível de Mestrado, na Faculdade de Odontologia de Bauru - Universidade de São Paulo (FOB-USP)

Professora da Universidade Paulista Campus Bauru

Curso de Pós-graduação em Ortodontia, nível Doutorado, na Faculdade de Odontologia de Bauru - Universidade de São Paulo (FOB-USP) 
Aos meus queridos pais José Armando e Ângela, pelo infinito amor e dedicação constante para a nossa formação moral e profissional.

Ao meu esposo Paulo Conti, pela ajuda na elaboração desse trabalho e pela convivência repleta de amor e compreensão .

Aos meus amados filhos, Sofia e Tomás, pela realização e oportunidade de vivenciar a expressão máxima de meu amor.

Dedico este trabalho 


\section{Agradecimentos;}

À minha irmã Ana Maria e meu cunhado Eugênio, pela convivência afetuosa.

À minha irmã Ana Cristina, pela alegria e entusiasmo.

$\mathcal{A}$ todos os meus familiares, em especial ao tio Chico Máximo pela presteza e carinho na revisão desse trabalho.

A toda família do meu esposo, D. Anna, Márcia, Carlos e Marina, pelo carinho com que me acolheram, em especial ao meu querido sogro José Valdes Conti, meu segundo pai, pelo constante apoio e incentivo.

Aos amigos Gêe e Elaine, IKe e Liliana, Juca e Sônia, Lauris e Rita, Neto e Marcela, Tonhão e Cris, Gu e Janja, Marcelo e Cláudia, e suas respectivas famílias, pela amizade e companheirismo.

À minha querida afilhada Carol, pela convivência alegre e afetuosa. 


\begin{abstract}
Ao Prof. Dr. Marcos Roberto de Freitas, orientador deste trabalho, pelo incentivo e apoio incondicionais na elaboração desta pesquisa e principalmente pelo carinho e amizade,
\end{abstract}

Expresso minha profunda gratidão. 
Agradeço ainda;

Aos Professores doutores Arnaldo Pinzan, Décio Rodrigues Martins, Guilherme dos Reis Pereira Janson, Renato Rodrigues de Almeida, pelos ensinamentos e experiências transmitidos.

Em especial ao Prof. Dr. José Fernando Castanha Henriques, coordenador do curso de doutorado, pelo incentivo e confiança durante todo o curso de pós-graduação.

Aos amigos do curso de Doutorado, Adriano, Ana Carla, Daniela, Danilo, Fausto, Karina, Karyna, Paulo, e Renata, e suas respectivas famílias, pelo companheirismo e lealdade que marcaram nossa caminhada.

Em especial à amiga Daniela Garib, pela amizade sincera e pelos esforços em busca de um objetivo comum, a prática docente. 
Aos funcionários da Disciplina de Ortodontia, Maria José Santos Formenti, Teresa Cristina Alves Camaforte Ducatti, e Daniel Francisco Rascão Selmo, ao amigo Luiz Sérgio Vieira, e em especial à Vera Lúcia Rodrigues Purgato, pela constante presteza e eficiência em nos ajudar.

À Profa. Dra. Maria Fidela de Lima Navarro, diretora da FOB-USP, ao Prof. Dr. Luiz Fernando Pegoraro, vicediretor, ao Prof. Dr. José Carlos Pereira, presidente da Comissão de PósGraduação, e ao Prof. Dr. José Fernando Castanha Henriques, prefeito do campus, pelo empenho em difundir conhecimentos e melhorar a nossa querida "FOB".

Aos professores e funcionários da UNIP, pela união e esforços para alcançar um objetivo comum, especialmente as amigas Ligia, Nildinha, Dani e Ana Luiza, da disciplina de Ortodontia e Odontopediatria.

Ao Professor Omar Gabriel da Silva Filho, pela gentileza em oferecer os pacientes do curso de Ortodontia da Profis para a realização dessa pesquisa.

Aos Funcionários da Clínica e Secretaria de PósGraduação, pela presteza com que sempre nos atenderam. 
Aos funcionários da Biblioteca, em especial a Sra. Rita, pelo auxílio na pesquisa bibliográfica deste trabalho.

Ao Prof. Dr. José Roberto Pereira Lauris pela orientação na análise estatística desta pesquisa.

A Sra. Edna Zaupa Nebo, pela ajuda na formatação deste trabalho.

À CAPES, pela concessão de bolsa de estudos. 


\section{SUMÁRIO}

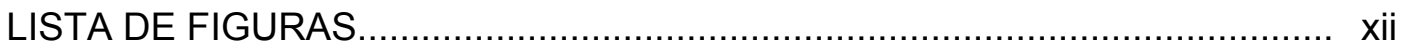

LISTA DE TABELAS ................................................................................... xiii

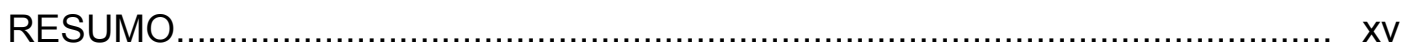

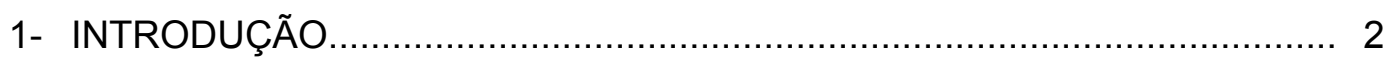

2- REVISÃO DE LITERATURA........................................................... 6

2.1. Tratamento ortodôntico e disfunção temporomandibular....................... 6

2.2. Protrusão mandibular ortopédica e disfunção temporomandibular......... 24

2.3. Posição condilar................................................................................... 33

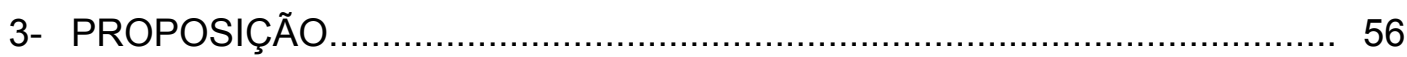

4- MATERIAL E MÉTODOS ................................................................. 58

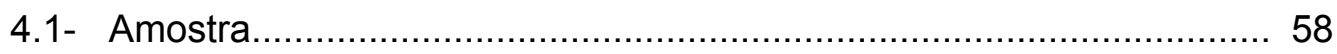

4.2- Aplicação do Questionário...................................................... 58

4.3- História Médica....................................................................... 60

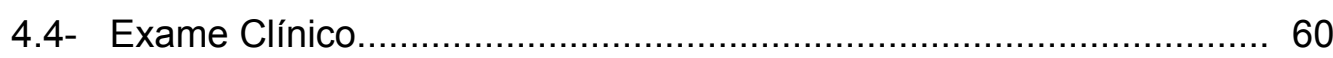

4.4.1- Avaliação da ATM................................................................. 61

4.4.2- Exame Muscular................................................................. 62

4.4.3- Avaliação Dentária e Oclusal................................................. 62

4.5- Exame Radiográfico....................................................................... 63

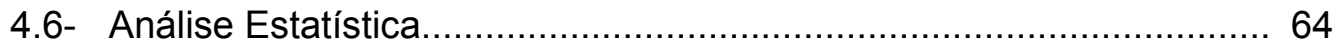

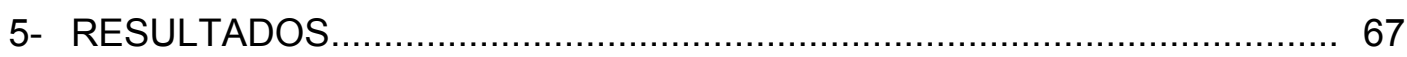

5.1- Característias Descritivas....................................................... 67

5.2- Disfunção temporomandibular................................................ 68

5.3- Concentricidade condilar......................................................... 83

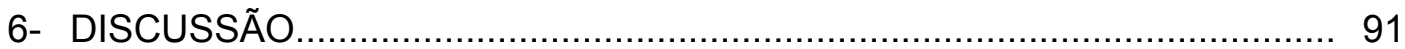

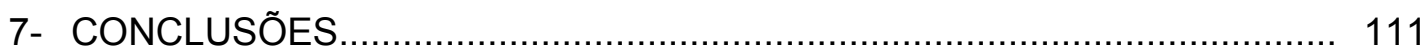

REFERÊNCIAS BIBLIOGRÁFICAS .................................................... 113

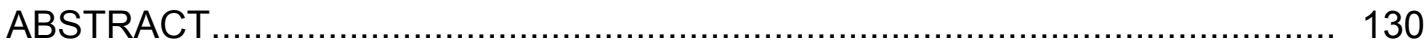

ANEXO 


\section{LISTA DE FIGURAS}

FIGURA 4.1: Questionário anamnésico. 59

FIGURA 4.2: Imagem transcraniana digitalizada. 64

FIGURA 5.1: Valores percentuais da presença e severidade de DTM em 69 cada grupo.

FIGURA 5.2: Valores percentuais dos indivíduos com e sem dor à 71 palpação da ATM nos diferentes grupos.

FIGURA 5.3: Valores percentuais dos indivíduos com e sem dor à 73 palpação dos músculos mastigatórios nos diferentes grupos.

FIGURA 5.4: Valores percentuais dos indivíduos com e sem facetas 74 dentárias nos diferentes grupos de DTM.

FIGURA 5.5: $\quad$ Valores percentuais dos indivíduos com e sem mordida 75 aberta anterior nos diferentes grupos de DTM.

FIGURA 5.6: Valores percentuais dos indivíduos com e sem mordida 76 cruzada unilateral nos diferentes grupos de DTM.

FIGURA 5.7: Valores percentuais dos indivíduos com diferentes relações $\quad 77$ sagitais nos diferentes grupos de DTM.

FIGURA 5.8: Valores percentuais dos indivíduos com diferentes 78 discrepâncias RC-MIH, nos diferentes grupos de DTM.

FIGURA 5.9: $\quad$ Valores percentuais dos indivíduos com diferentes padrões $\quad 79$ de lateralidade direita nos diferentes grupos de DTM.

FIGURA 5.10: Valores percentuais dos indivíduos com diferentes padrões 80 de lateralidade esquerda nos diferentes grupos de DTM.

FIGURA 5.11: Valores percentuais dos indivíduos com e sem guia anterior, nos diferentes grupos de DTM.

FIGURA 5.12: Valores percentuais dos indivíduos com diferentes padrões de contato no lado de não-trabalho direito nos diferentes grupos de DTM.

FIGURA 5.13: Valores percentuais dos indivíduos com diferentes padrões de contato no lado de não-trabalho esquerdo nos diferentes grupos de DTM. 
FIGURA 5.14: Valores percentuais e desvio-padrão da concentricidade condilar nos diferentes grupos.

FIGURA 5.15: Médias de concentricidade condilar nos diferentes grupos, 86 considerando-se apenas as ATMs direitas.

FIGURA 5.16 Concentricidade condilar dos lados direito e esquerdo.

FIGURA 5.17 Correlação entre a concentricidade condilar e o índice de 89 DTM. 


\section{LISTA DE TABELAS}

TABELA 5.1: Valores (em $\mathrm{mm}$ ) das médias e desvios padrão acompanhados dos valores mínimo e máximo da abertura, lateralidades direita e esquerda e protrusão da amostra total.

TABELA 5.2: Valores (em $\mathrm{mm}$ ) das médias e desvios padrão 68 acompanhados dos valores mínimos e máximos dos trespasses horizontal e vertical e do número de contatos em MIH da amostra total.

TABELA 5.3: Prevalência de DTM nos diferentes grupos (valores 68 absolutos e percentuais).

TABELA 5.4: Valores absolutos e percentuais das respostas ao 70 questionário de DTM nos diferentes grupos

TABELA 5.5: Valores absolutos e percentuais do número de indivíduos com e sem dor à palpação da ATM

TABELA 5.6: Valores absolutos e percentuais do número de indivíduos com e sem dor à palpação dos músculos mastigatórios.

TABELA 5.7: Valores absolutos e percentuais do número de indivíduos com facetas dentárias nos diferentes grupos de DTM.

TABELA 5.8: Valores absolutos e percentuais do número de indivíduos com e sem mordida aberta anterior nos diferentes grupos de DTM.

TABELA 5.9: Valores absolutos e percentuais do número de indivíduos com mordida cruzada unilateral nos diferentes grupos de DTM

TABELA 5.10: Valores absolutos e percentuais do número de indivíduos com diferentes relações sagitais nos diferentes grupos de DTM.

TABELA 5.11: Valores absolutos e percentuais do número de indivíduos com diferentes posicionamentos condilares sagitais nos diferentes grupos de DTM.

TABELA 5.12: Valores absolutos e percentuais do número de indivíduos com diferentes padrões de guia de lateralidade direita, nos diferentes grupos de DTM. 
TABELA 5.13: Valores absolutos e percentuais do número de indivíduos com diferentes padrões de guia de lateralidade esquerda nos diferentes grupos de DTM

TABELA 5.14: Valores absolutos e percentuais do número de indivíduos com e sem guia anterior nos diferentes grupos de DTM.

TABELA 5.15: Valores absolutos e percentuais do número de indivíduos com diferentes padrões de contatos em não trabalho do lado direito nos diferentes grupos de DTM.

TABELA 5.16: Valores absolutos e percentuais do número de indivíduos com diferentes padrões de contato em não-trabalho do lado esquerdo nos diferentes grupos de DTM.

TABELA 5.17: Valores (em $\mathrm{mm}$ ) das médias e desvios padrão 84 acompanhados dos valores máximos e mínimos dos espaços articulares anterior $(A)$ e posterior $(P)$, para os lados direito e esquerdo de toda a amostra.

TABELA 5.18: Valores (em $\mathrm{mm}$ ) das médias e desvios padrão 84 acompanhados dos valores máximos e mínimos dos espaços articulares anterior $(A)$ e posterior $(P)$, para os lados direito e esquerdo dos grupos I, II e III.

TABELA 5.19: Médias percentuais seguidas dos desvios padrão dos valores de concentricidade condilar nos grupos estudados.

TABELA 5.20: Médias percentuais seguidas dos desvios padrão dos valores de concentricidade condilar nos grupos estudados, considerando-se apenas as ATMs direitas.

TABELA 5.21: Médias percentuais seguidas dos desvios padrão dos valores de concentricidade condilar nos grupos estudados, considerando-se apenas as ATMs esquerdas.

TABELA 5.22: Médias (em $\mathrm{mm}$ ) seguidas dos desvios padrão dos valores dos espaços articulares superiores nos grupos estudados (lado direito).

TABELA 5.23: Médias (em $\mathrm{mm}$ ) seguidas dos desvios padrão dos valores dos espaços articulares superiores nos grupos estudados (lado esquerdo). 
Resumo 


\section{RESUMO}

O objetivo deste trabalho foi avaliar a participação da protrusão mandibular ortopédica e da posição condilar na prevalência de sinais e sintomas de disfunção temporomandibular (DTM). A amostra foi composta por 60 indivíduos divididos proporcionalmente em três grupos. O grupo I foi constituído por jovens indicados para tratamento da má oclusão de Classe II, com o aparelho Bionator, e o grupo II foi composto por jovens avaliados durante o tratamento com o aparelho Bionator. Pacientes já submetidos à terapia com o mesmo tipo de aparelho formaram o grupo III. Um questionário relativo aos principais sintomas de DTM permitiu a elaboração de um índice anamnésico, objetivando classificar a amostra de acordo com a presença e severidade dessas disfunções. Foi realizado exame de palpação dos músculos mastigatórios e cervicais, e da articulação temporomandibular (ATM), além de detecção de ruídos articulares e análise da movimentação mandibular. Radiografias transcranianas padronizadas das ATMs direita e esquerda foram executadas com a boca fechada e abertura máxima. Os espaços articulares anterior e posterior foram mensurados nas radiografias digitalizadas, para obtenção do grau de concentricidade condilar. ANOVA a um critério, teste de Kruskal-Wallis e qui-quadrado foram utilizados para análise dos dados. De acordo com os resultados do questionário anamnésico, 66,67\% da amostra foram classificados com ausência de DTM, $30 \%$ com DTM leve e apenas 3,33\% com DTM moderada, sem diferença entre os grupos estudados ( $p>0,05)$. Quanto à concentricidade condilar, 0 grupo II apresentou os valores de menor concentricidade (côndilos mais anteriorizados), com diferença estatisticamente significante em relação ao grupo I $(p<0,05)$. Uma associação entre a concentricidade condilar e a prevalência de DTM, no entanto, não foi encontrada. Concluiu-se que a protrusão ortopédica, apesar de alterar a posição dos côndilos, não aumentou a prevalência de DTM na população estudada. 
1- Introdução 


\section{1- INTRODUÇÃO}

As disfunções do sistema mastigatório têm alcançado um papel de destaque dentro do contexto odontológico das últimas décadas. A grande demanda de pacientes e a pequena quantidade de informação disponível na área fazem com que se multipliquem estudos na busca de respostas que possam contribuir para tratamentos mais eficazes.

As chamadas disfunções temporomandibulares (DTMs) apresentam sinais característicos como dor ou sensibilidade na região dos músculos da mastigação ou articulação temporomandibular (ATM), ruídos durante o movimento condilar, limitação ou incoordenação do movimento mandibular e incorreto relacionamento entre as posições mandibulares.

Historicamente, o responsável pelo início dos estudos nessa área foi $\operatorname{COSTEN}{ }^{20,21}$, um otorrinolaringologista, que relatou uma série de sintomas como problemas auditivos, zumbido, dor ao redor dos ouvidos e vertigens, que ficou conhecida por Síndrome de Costen.

A partir dos trabalhos de COSTEN ${ }^{20,21}$, várias nomenclaturas foram sugeridas de acordo com as diversas teorias etiológicas. Mais recentemente, o termo Disfunção Temporomandibular tem sido aceito.

Recentes estudos epidemiológicos sugerem que aproximadamente $3 / 4$ da população podem, de alguma forma, possuir algum tipo de alteração funcional do sistema mastigatório.

Porém, apesar de bastante prevalentes em estudos populacionais, a maioria dos sintomas são esporádicos e auto-limitantes.

O grande problema na aceitação de resultados expressivos em relação à prevalência é o crescente perigo de se considerar necessário um tratamento excessivo aos considerados "pacientes". Para expressar a preocupação com tal problema, ILLICH ${ }^{50}$ escreveu: "A grande soma de cuidados clínicos contemporâneos é acessório na cura das doenças, mas o 
dano feito pela medicina à saúde dos indivíduos e população é muito significante. Esses fatos são óbvios, bem documentados e mal divulgados".

Em relação à etiologia de tais problemas, os fatores oclusais, associados a fatores psicológicos e sistêmicos parecem, levar o indivíduo a apresentar algum sintoma de DTM.

De acordo com o postulado de Koch, para estabelecer um relacionamento causal entre um fator e a doença, os seguintes critérios devem estar presentes: 01) o fator deve ser observado em todos os casos da doença; 02) esse fator, se introduzido a um ser suscetível e assintomático, deve produzir a doença. Dessa forma as discrepâncias oclusais, assim como as instabilidades emocionais, não se enquadram totalmente nesse contexto.

A aceitação da idéia de que a oclusão exerce o papel principal na etiologia das DTMs vem da observação do sucesso obtido com vários tratamentos oclusais. Porém, isso não demonstra uma relação causal, já que a disfunção é episódica, apresentando remissão espontânea em muitos casos, além do fato que, em algumas situações o sucesso é conseguido também com terapias alternativas como "biofeedback", fisioterapia, etc. ${ }^{19}$.

Além disso, trabalhos recentes ${ }^{18,108,109,124}$ demonstram ausência de associação entre os diversos fatores oclusais e sintomas de DTM, quando mensurados por meio de um questionário anamnésico.

Outro fator constantemente citado na literatura como causador das DTMs é o tratamento ortodôntico. Por outro lado, também é sugerida a realização de tratamento ortodôntico para prevenção de sinais e sintomas de DTM, o que gera confusão entre os pesquisadores.

$\mathrm{Na}$ verdade, a realização de procedimentos de Ortodontia não parece predispor o indivíduo a apresentar DTM ${ }^{16,18}$.

Um dos procedimentos freqüentemente utilizados na fase de crescimento do indivíduo com má oclusão de Classe II é a estimulação do crescimento mandibular, utilizando-se de conceitos ortopédicos. 
Essa estimulação é obtida por meio de aparelhos intra-orais, que protruem a mandíbula, buscando um crescimento ósseo na região dos côndilos e fossa mandibular. Aparelhos removíveis, do tipo Bionator e fixos, do tipo Herbst são os mais comumente utilizados com esse propósito. $O$ grau de crescimento e a estabilidade da nova relação oclusal ainda são motivo de controvérsia e objetos de pesquisa.

Como conseqüência dessa protrusão ortopédica, há também uma anteriorização do côndilo dentro da fossa mandibular, obrigando todo o complexo côndilo/disco a acompanhar esse movimento durante certo período de tempo. Além disso, essa nova postura mandibular anteriorizada exige nova acomodação das fibras musculares. Parece claro, então que esse tipo de terapia realmente leva a uma série de alterações no sistema estomatognático.

No entanto, apesar dessas várias alterações, pouco ainda se conhece sobre o verdadeiro efeito da protrusão como agente predisponente, iniciador ou perpetuante das DTMs. A literatura é escassa em estudos que avaliam a relação entre a posição mandibular anteriorizada pós-tratamento ortopédico e DTM. Será que os côndilos retornariam às suas posições originais ao final do tratamento ortopédico com a estabilização da oclusão? Outra questão ainda a ser respondida: Qual seria o risco, do paciente mantido por algum tempo com os côndilos fora da posição "normal", vir a desenvolver DTM. A importância da concentricidade condilar para a saúde da articulação temporomandibular também faz parte desse cenário como um dos temas históricos de discussão e controvérsia entre clínicos e pesquisadores.

Com o intuito de contribuir para melhor entendimento dessas questões, este trabalho tem como finalidade avaliar a relação existente entre posição condilar, sinais e sintomas de DTM e protrusão mandibular ortopédica. 
2- Revisão de Literatura 


\section{2- REVISÃO DE LITERATURA}

O termo Disfunção Temporomandibular envolve um número de problemas clínicos relacionados aos músculos mastigatórios, à articulação temporomandibular e estruturas adjacentes, ou ambos ${ }^{79}$. Muitas teorias tentaram explicar a etiologia das DTMs. Um fator etiológico específico ainda não foi isolado, e atualmente acredita-se que a causa dessas disfunções seja multifatorial.

O tratamento ortodôntico foi apontado como um fator contribuinte para o desenvolvimento das DTMs, e desde então muitos estudos têm sido realizados no intuito de elucidar a real participação da ortodontia na etiologia destas desordens. Para estudar a influência do tratamento ortodôntico nas DTMs torna-se necessário conhecer a evolução desses problemas, desde os primeiros relatos na literatura até os dias de hoje.

\section{1- Tratamento ortodôntico e Disfunção Temporomandibular}

Hipócrates, já no século $V$ a.C., relatou uma manobra de redução de deslocamento da mandíbula realizada pelos egípcios 2500 anos antes, revelando, então, problemas relacionados a ATM.

Os estudos anatômicos da mandíbula e da ATM propiciados por Leonardo da Vinci (Séc. XV), Andreas Vesalius (Séc. XVI) e John Hunter (Séc. XVIII) forneceram meios precisos para o conhecimento das estruturas da ATM.

PRENTISS $^{91}$, em 1887, atribuiu à diminuição da dimensão vertical de oclusão a causa da síndrome de disfunção da ATM. A perda dos dentes posteriores acarretava um deslocamento mecânico da mandíbula e 
os côndilos atuavam pressionando a tuba de Eustáquio. Esta teoria foi chamada de Teoria do deslocamento mecânico da mandíbula.

O primeiro relato minucioso dos sintomas e da origem dos problemas articulares foi descrito por COSTEN ${ }^{20,21}$, na década de 30. Esse relato foi baseado na detecção de alguns sintomas em 11 pacientes, como dores de cabeça e, ao redor dos ouvidos, zumbidos, ruídos articulares, boca e garganta secas. Esse conjunto de sintomas foi chamado de Síndrome de Costen, a qual, segundo o autor, era desencadeada pela perda de suporte dentário posterior e fechamento exagerado da mandíbula, acarretando uma pressão dos côndilos sobre as estruturas retrocondilares.

Porém, SICHER ${ }^{117}$, em 1948, criticou a suposta pressão do côndilo sobre o nervo corda do tímpano advogada por COSTEN ${ }^{20,21}$. Este autor alegou que a pressão sobre o citado nervo apenas seria possível com a fratura da fissura petrotimpânica.

SCHWARTZ ${ }^{114}$, em 1955, propôs o termo "Síndrome DorDisfunção da Articulação Temporomandibular". Relatou, ainda, que essa síndrome só acometia pacientes predispostos por sua constituição, devido a estiramentos ou mudanças proprioceptivas causadas por alterações na oclusão dos dentes.

Mais recentemente, outra terminologia para os problemas relacionados à $A T M$ e músculos mastigatórios foi proposta por $\operatorname{LASKIN}^{62}$, em 1969. De acordo com este autor, os espasmos musculares, devido à fadiga, seriam o fator primário no desenvolvimento dos sintomas. A fadiga muscular seria o resultado de hábitos bucais involuntários realizados para alívio de tensão emocional. Outros fatores agiriam perpetuando o processo, como desarmonias oclusais e artrite degenerativa. Denominou-se esta teoria de psicofisiológica e a nova terminologia-"Síndrome Dor-Disfunção Miofascial" (SDDMF), utilizada por muitos profissionais até nossos dias. 
O estudo da prevalência e etiologia das DTMs experimentou grande avanço com o início de pesquisas epidemiológicas realizadas com o uso de questionários e exame clínico. Desta forma, em 1972, AGERBERG; CARLSSON $^{1}$ obtiveram resultados de um questionário enviado para 1106 indivíduos, com idade média de 35 anos. Esse questionário consistia de perguntas sobre o estado funcional das estruturas mastigatórias. A freqüência de dor de cabeça e dores faciais foi de $24 \%$, os ruídos articulares foram relatados por $39 \%$ dos indivíduos e a limitação de movimentos mandibulares ( $7 \%$ da amostra) foi mais freqüente no gênero feminino.

Utilizando-se dos mesmos dados do trabalho anterior, AGERBERG; CARLSSON ${ }^{2}$ estipularam um índice, o qual mostrou maiores valores para o gênero feminino, porém com suaves diferenças. Dos 1106 entrevistados, 57\% apresentavam um sintoma, enquanto dois sintomas ou mais acometiam 30\% dessa amostra. Considerando o fator idade, a limitação de movimentos mandibulares foi mais freqüente nos indivíduos mais idosos, e as dores funcionais, mais comum nos jovens.

Um grande avanço para o estudo das desordens da ATM foi alcançado em 1974, quando $\mathrm{HELKIMO}^{38,39}$ publicou uma série de artigos propondo um índice anamnésico e um clínico para o diagnóstico dessas desordens. Esses índices permitiram a realização de estudos epidemiológicos nessa área, assim como possibilitaram a classificação dos pacientes de acordo com a severidade dos sintomas e sinais de DTM. Os pacientes eram classificados em três níveis, de acordo com o índice anamnésico (sem sintomas, médio, severo) e em quatro níveis a partir do índice clínico (sem sinais, médio, moderado, severo).

$\mathrm{HELKIMO}^{40}$, nessa série de artigos, publicou resultados mais precisos dos índices. Relatou que nos indivíduos classificados como índice anamnésico severo, $75 \%$ apresentavam, pelo menos, um sintoma severo e $44 \%$ descreveram dois ou mais sintomas. Nos indivíduos classificados com ausência de sintomas, apenas 18\% eram considerados clinicamente 
assintomáticos. Comprovou-se a validade do emprego do índice como meio de identificação das desordens da ATM e musculatura mastigatória.

Considerando a idade e o gênero, HELKIMO ${ }^{41}$ relatou a mesma prevalência entre indivíduos do gênero feminino e masculino. Segundo o autor, a prevalência de sintomas varia bastante entre as várias faixas etárias, dependendo do sintoma analisado. O grupo entre 15 e 24 anos mostrou-se com a mais baixa freqüência de sintomas. Devido às diferenças desses resultados relacionados à idade e ao gênero, com resultados prévios, concluiu-se que esses dados não podem ser extrapolados para a população.

Em 1976, HELKIMO ${ }^{42}$ enfatizou a necessidade de uniformizar as pesquisas nessa área, para se esclarecer aspectos ainda obscuros das desordens da ATM. Relatou que os sintomas são muito comuns em uma população aleatória e afirmou que não existem diferenças entre os sexos em relação à prevalência de sintomas. Ressaltou, ainda, o caráter multifatorial da etiologia das desordens do sistema mastigatório.

Em 1979, SOLBERG; WOO; HOUSTON ${ }^{119}$ avaliaram a prevalência de disfunção mandibular em 739 jovens, metade de cada gênero, pertencentes à Universidade da Califórnia, em Los Angeles. Foi aplicado um questionário contendo seis perguntas sobre sintomas, cinco itens sobre as reações aos sintomas e um exame clínico para averiguar seis sinais e duas medidas das relações maxilomandibulares. Constatou-se que $16,8 \%$ dos jovens apresentavam um sintoma, $9 \%$ tinham dois ou mais sintomas e apenas quatro indivíduos apresentavam cinco sintomas. Os ruídos articulares acometiam $28,3 \%$ dos jovens, sendo $16,6 \%$ estalidos e $11,5 \%$ de crepitação. No exame de palpação muscular foi constatado que $30 \%$ apresentavam de um a três locais sensíveis. Concluiu-se também que as jovens do gênero feminino demonstraram maior prevalência de sinais associados com a disfunção mandibular quando comparadas aos jovens do gênero masculino. 
Em 1980, SADOWSKY; BEGOLE ${ }^{108}$ realizaram um estudo comparando 75 indivíduos que tinham se submetido a tratamento ortodôntico quando adolescentes, com uma amostra de 75 indivíduos que nunca receberam tratamento ortodôntico. Os autores avaliaram a oclusão funcional com a função da articulação temporomandibular e encontraram bastante similaridade na prevalência de sinais e sintomas nas articulações temporomandibulares, entre os grupos.

Em 1981, JANSON; HASUND ${ }^{53}$ analisaram 60 pacientes tratados ortodonticamente quando adolescentes, numa média de cinco anos após a contenção. A amostra foi dividida em 30 pacientes que tiveram extração de quatro pré-molares e em outros 30 que não tiveram extrações, mas receberam uma combinação de aparelho extrabucal e ativador, seguido de aparelhagem fixa. Um grupo controle de 30 pacientes não tratados foi utilizado. Os autores concluíram que não haveria risco significante de desenvolver disfunção da ATM quando pacientes com má oclusão relativamente severa fossem tratados ortodonticamente.

Em 1983, WILLIAMSON ${ }^{138}$ descreveu o papel das DTM no diagnóstico e plano de tratamento em ortodontia. Relatou a importância de se realizar um exame criterioso de sinais e sintomas de DTM antes de se iniciar o tratamento ortodôntico, para que o paciente seja alertado quando da presença desses sinais e/ou sintomas. Nos casos em que se detecta a presença de estalidos, deve-se tentar recapturar o disco antes de iniciar o tratamento, e quando o paciente já se encontra com travamento bucal fechado, indica-se o tratamento para estabilizar a oclusão e aliviar a dor antes de procedimentos irreversíveis.

SADOWSKY; POLSON ${ }^{109}$ (1984) objetivaram elucidar os aspectos da oclusão funcional pós-ortodontia e seus efeitos nas DTMs utilizando resultados de dois estudos longitudinais. Uma amostra de 96 pacientes tratados ortodonticamente em Illinois foi comparada a um grupo controle de 103 indivíduos com má oclusão não tratada. O outro estudo compreendeu 111 pacientes tratados no Centro de Eastman e um grupo 
controle de também 111 indivíduos não tratados ortodonticamente. Os pacientes foram examinados pelo menos 10 anos após o término do tratamento, respondendo a um questionário anamnésico e submetendo-se à palpação para verificação de ruídos articulares e inspeção sobre as condições da oclusão funcional. Ambos estudos não demonstraram relação entre o tratamento ortodôntico fixo e a prevalência de sinais e sintomas de DTM. Os autores encontraram, ainda, similaridade na prevalência de contatos oclusais não funcionais entre os grupos experimental e controle. Assim, os dois estudos que foram conduzidos separadamente indicaram a não influência do tratamento ortodôntico fixo realizado na adolescência, no posterior desenvolvimento de DTM.

Em 1985, SADOWSKY et al. ${ }^{110}$ examinaram 98 pacientes préortodontia, 176 durante o tratamento ortodôntico ativo e 73 pacientes póstratamento, estabelecendo a prevalência de ruídos articulares e sua possível relação com a ortodontia. Quando os ruídos articulares foram clinicamente identificados pelos examinadores, encontrou-se uma diferença estatisticamente significante entre os grupos. A prevalência para o grupo pré-tratamento foi de $40,8 \%$, sendo de $60,8 \%$ para o grupo em tratamento e $68,5 \%$ para os jovens já tratados. Entretanto, o fator idade também influenciou a prevalência de ruídos nos grupos, antes e durante o tratamento. Desta maneira, não se esclareceu se os ruídos articulares se relacionam com a idade, com o tratamento ortodôntico ou com ambos.

Em 1986, WÄNMAN; AGERBERG ${ }^{127}$ averiguaram a prevalência de sintomas de DTM em 285 adolescentes com 17 anos de idade. Os sintomas mais encontrados foram ruídos articulares, fadiga muscular e dores de cabeça. Considerando o fator gênero, não se observou diferença em relação à prevalência de sintomas entre os adolescentes do gênero feminino e masculino. Do total da amostra, $7 \%$ relataram sintomas classificados como severos. Os autores sugerem que durante o exame ortodôntico de rotina atenção especial deve ser dada aos sintomas de DTM mais freqüentes. 
No mesmo ano, WÄNMAN; AGERBERG ${ }^{128}$ estudaram também a prevalência de sinais de DTM na mesma amostra do estudo anterior. As adolescentes do gênero feminino apresentaram maior freqüência de sinais, sendo que para toda a amostra a prevalência dos sinais de DTM foi de $56 \%$. Os ruídos articulares e a sensibilidade à palpação muscular foram os sinais mais detectados. A prevalência de sensibilidade muscular foi de $41 \%$, sendo o pterigoideo lateral e a inserção do músculo temporal os locais mais acometidos.

Ainda utilizando-se da mesma amostra, WÄNMAN; AGERBERG ${ }^{129,130}$ estudaram os sinais e sintomas, dois anos mais tarde, quando os adolescentes apresentavam, em média, 19 anos. As jovens do gênero feminino entre 18 e 19 anos relataram mais sintomas, principalmente ruídos articulares e dores de cabeça. Em relação aos sinais, o gênero feminino também foi o mais acometido, embora aqueles tenham variado bastante nas observações anuais. Alterações em relação aos sinais e sintomas de DTM não foram observadas em $60 \%$ da amostra.

Em 1987, DIBBETS; VAN DER WEELE ${ }^{23}$ avaliaram a relação entre tratamento ortodôntico e sintomas atribuídos à disfunção da ATM. Foram comparados 63 pacientes tratados com aparelho ativador modificado e 72 pacientes tratados com aparelho fixo pela técnica de Begg, com uma amostra controle na fase pré-tratamento. Os autores relataram um aumento nos sinais de $21 \%$ a $41 \%$ em todos os grupos, o que foi atribuído ao aumento de idade e não ao tratamento ortodôntico. Concluiu-se que o tratamento ortodôntico não provoca as disfunções de ATM. Embora o grupo com aparelhagem fixa apresentasse mais sintomas que o grupo de aparelhos funcionais, esta diferença não mais existiria após 10 anos de controle.

Nesse mesmo ano, WYATT ${ }^{140}$ apontou os procedimentos ortodônticos que mais comumente podem comprometer as condições da ATM, aumentando os riscos dos pacientes apresentarem sinais e sintomas de DTM. Segundo os autores, os elásticos de Classe II e o aparelho 
extrabucal utilizados na correção da má oclusão de Classe II são exemplos desses procedimentos. Os elásticos para correção de desvios de linha média, as mentoneiras, os procedimentos de fechamento de espaços sem abrir a mordida, nos casos de sobremordida acentuada, e os dispositivos de contenção também foram considerados fatores de risco. Esses procedimentos poderiam pressionar o complexo côndilo-disco para posterior, iniciando processos patológicos intra-articulares.

Contestando o artigo de WYATT ${ }^{140}$, RINCHUSE ${ }^{102}$, ainda em 1987, revisou alguns trabalhos, questionando a participação de tais procedimentos ortodônticos na etiologia das DTMs. Se fosse verdadeiro que algumas modalidades terapêuticas ortodônticas aumentassem os riscos de DTM, a prevalência de sinais e sintomas de DTM deveria ser maior em pacientes tratados ortodonticamente, quando comparados a um grupo controle não tratado. Como a maioria dos trabalhos não comprova esta hipótese, sugeriu-se que estes procedimentos não devem ser abandonados, até comprovação científica da participação dos mesmos na etiologia das DTMs.

DAHL et al. ${ }^{22}$, em 1988, compararam, em termos de prevalência de sinais e sintomas de DTM, 51 indivíduos previamente tratados ortodonticamente com um grupo controle de 47 indivíduos não tratados, em média com 19 anos de idade. Foram empregados um índice de disfunção anamnésico e os índices oclusal e clínico de disfunção de Helkimo. Quanto ao índice clínico de disfunção, os dois grupos apresentaram resultados semelhantes, com índices de disfunção leve de $43,1 \%$ para o grupo tratado e de $40 \%$ para o grupo controle. Foram detectados sintomas moderados em $27,5 \%$ e $12 \%$, respectivamente para os grupos tratado e controle. Entretanto, os sintomas relatados pelo questionário indicaram mais indivíduos no grupo controle com sintomas moderados (ruídos articulares, fadiga muscular ao acordar ou durante os movimentos mandibulares). Concluiu-se que o grupo tratado e o não tratado ortodonticamente assemelham-se em relação aos sinais e sintomas de DTM. 
A relação entre má oclusão e ruídos articulares foi averiguada por RUNGE et al. ${ }^{106}$ (1989), examinando 226 pacientes antes de iniciarem o tratamento ortodôntico. Os pacientes responderam a quatro questões sobre a ATM, sendo também avaliados quanto aos aspectos funcionais e estáticos da oclusão e o tipo de má oclusão, de acordo com Angle. Análises referentes aos trespasses vertical e horizontal e à presença de mordida cruzada também foram realizadas. A presença de ruídos foi detectada em $36,3 \%$ da amostra, o que se relacionou com a idade, porém não com o gênero, com a mordida cruzada ou tipo de má oclusão. Concluiu-se que a oclusão estática e funcional e as relações esqueletais parecem não se correlacionar com os ruídos articulares.

Ainda em 1989, NIELSEN; MELSEN; TERP ${ }^{77}$ avaliaram 706 adolescentes dinamarqueses entre 14 e 16 anos de idade, em relação a sinais de disfunção do sistema mastigatório. Concluiu-se que $10 \%$ dos adolescentes apresentavam problemas compatíveis com tratamento, $67 \%$ exibiam um ou mais pontos sensíveis na palpação muscular e em $6,8 \%$ foi detectada a presença de estalidos.

Em 1990, NIELSEN; MELSEN; TERP ${ }^{78}$, utilizando-se da mesma amostra do estudo anterior, investigaram a participação do tratamento ortodôntico na condição do sistema mastigatório. 48,3\% da amostra tinham sido tratados ortodonticamente. A comparação desse grupo com o não tratado demonstrou maior prevalência de sensibilidade à palpação muscular e articular no grupo tratado ortodonticamente. Em relação à presença de ruídos articulares, observou-se uma similaridade na prevalência entre os grupos.

Ainda em 1990, REYNDERS ${ }^{101}$ concluiu uma extensa revisão da literatura pertinente à relação entre ortodontia e DTM. Essa revisão compreendeu 91 artigos de 1966 a 1988, divididos em 55 artigos de opinião pessoal, 30 relatos de caso clínico e apenas seis artigos baseados em estudos com amostras. Devido à falta de confiabilidade nos resultados dos artigos de caso clínico e opinião pessoal, restam apenas poucos artigos para 
se tentar elucidar se o tratamento ortodôntico causa, cura ou não tem efeito nas DTMs. Os resultados dos estudos com amostras indicam que 0 tratamento ortodôntico fixo durante a adolescência não influencia o risco de desenvolver DTM. Em relação aos tipos de aparelhos, os estudos longitudinais não mostraram diferenças na incidência de sinais e sintomas de DTM. Pacientes tratados sem extração e com ativador, quando comparados aos pacientes tratados com aparelhagem fixa e extração de quatro pré-molares, apresentavam índices similares de DTM.

DIBBETS; VAN DER WEELE ${ }^{24}$, em 1991, analisaram as relações entre ortodontia, extrações e Disfunções Temporomandibulares em um estudo longitudinal de 15 anos, utilizando uma amostra de 172 pacientes ortodônticos. Da amostra, 39\% tinham utilizado aparelhos removíveis, 44\% receberam aparelhagem fixa e 17\% utilizaram mecânica de Begg para Classe III ou mentoneira. O critério de extrações também foi considerado. Os autores concluíram que não houve diferença nos sinais e sintomas de DTM em relação aos três tipos de tratamento. Afirmaram também que, ao contrário do que se pensava, o fator responsável pelo surgimento de sintomas de DTM foi o padrão de crescimento e não a realização prévia de extrações.

Em uma revisão da literatura a respeito da etiologia das DTM, principalmente dos fatores oclusais e tratamento ortodôntico, BAKER; CATANIA; BAKER JUNIOR ${ }^{6}$ (1991) não consideraram a oclusão como fator significante no desenvolvimento das DTMs. Relataram, ainda, a não participação da ortodontia e das extrações dentárias como causa de tais patologias.

Achados similares foram encontrados por SADOWSKY ${ }^{107}$, em 1992, em sua revisão de literatura, relacionando o tratamento ortodôntico às Disfunções Temporomandibulares. O tratamento ortodôntico realizado na infância ou adolescência não foi considerado um fator de risco no desenvolvimento de DTM. Essa conclusão foi obtida pelo autor baseado em dois fatores: primeiro, existe uma multiplicidade de fatores que podem ser 
responsáveis por causar ou exacerbar as DTMs; segundo, a mecanoterapia ortodôntica realiza mudanças graduais em um ambiente com grande capacidade adaptativa.

Nesse mesmo ano, DIBBETS; VAN DER WEELE ${ }^{25}$, em um estudo longitudinal de 20 anos, relacionaram os efeitos do tratamento ortodôntico, incluindo as extrações aos sinais e sintomas de DTM. Considerou-se a técnica empregada (aparelhos removíveis, técnica de Begg associada a elásticos de Classe II, e técnica de Begg ou mentoneiras para Classe III) e a extração de dentes (sem extrações, extrações dos quatro prémolares, e outros tipos de extrações). Após 20 anos, 172 pacientes foram avaliados quanto à presença de sinais e sintomas de DTM, sendo que a presença destes não se relacionou ao tipo de técnica ortodôntica e nem ao tipo de extrações realizadas ou não.

Ainda em 1992, FÔNSECA ${ }^{29}$ propôs-se a verificar a confiabilidade de um questionário anamnésico, comparado ao índice clínico modificado de Helkimo, avaliando 120 pacientes de DTM. Obteve-se um índice de confiabilidade de $95 \%$ devido à alta correlação entre respostas do questionário e achados clínicos. Sugeriu-se a adoção desse índice anamnésico devido às suas vantagens de menor custo e rapidez, sendo indicado para pesquisas epidemiológicas, em serviços públicos.

Em 1993, WADHWA; UTREJA; TEWARI ${ }^{126}$ realizaram um estudo clínico comparando sinais e sintomas de DTM em 30 indivíduos com oclusão normal não tratados, 41 com má oclusão também não tratados e 31 indivíduos tratados ortodonticamente, com idades entre 13 e 25 anos, moradores da região norte da Índia. Utilizando o índice de Helkimo, não se encontrou diferença entre os grupos em relação ao índice anamnésico, sendo que a porcentagem de sintomas apresentou-se baixa, comparando-se com outros trabalhos da literatura. Essa diferença foi atribuída à falta de informação em relação às DTMs nas populações orientais, comparadas com as ocidentais. Em relação ao índice clínico de disfunção, o grupo com oclusão normal apresentou maior porcentagem $(46,7 \%)$ de indivíduos livres 
de sinais e sintomas de DTM, comparados com 19,6\% do grupo com má oclusão, não tratados, e $22,6 \%$ do grupo tratado. A avaliação de ruídos articulares apontou uma porcentagem de $35,5 \%$ do total da amostra.

Avaliação dos fatores de risco associados aos ruídos articulares em crianças de 6 a 12 anos foi realizada por KEELING et al. ${ }^{55}$, em 1994. A amostra foi composta por 3742 crianças, as quais foram submetidas à inspeção relacionada a dados pessoais, relação sagital, história de trauma, presença de má oclusão, função mandibular e relação dos tecidos moles. Evidenciou-se a presença de ruídos articulares em 10\% das crianças, dado este associado à sobremordida acentuada, apinhamento anterior severo e capacidade de abertura bucal aumentada. Não se correlacionaram os ruídos articulares com o gênero ou a idade das crianças examinadas.

Um trabalho de grande contribuição científica foi realizado por MCNAMARA JUNIOR; SELIGMAN; OKESON ${ }^{72}$, em 1995. Baseados numa extensa revisão literária, os autores estabeleceram cinco fatores de risco quando relacionamos oclusão com Disfunções Temporomandibulares. Esses fatores são:

- Mordida aberta anterior esquelética;

- Trespasse horizontal maior que 6-7 mm

- Diferença maior que $4 \mathrm{~mm}$ entre Relação Central (RC) e Máxima Intercuspidação Habitual (MIH).

- Mordida cruzada unilateral.

- Cinco ou mais dentes posteriores perdidos.

Os autores concluíram que os três primeiros fatores estão freqüentemente associados a artropatias da ATM e podem ser o resultado de alterações ósseas e ligamentosas dentro da ATM. Em relação à 
ortodontia, eles afirmaram que, de acordo com a literatura atual, todo e qualquer tipo de mecânica ortodôntica realizada durante a adolescência não aumenta nem diminui as chances de posterior desenvolvimento de Disfunções Temporomandibulares.

Em 1996, DIBBETS; VAN DER WEELE ${ }^{26}$ verificaram a associação de sinais e sintomas de DTM e a forma craniofacial de uma amostra de pacientes ortodônticos aos 12,5 anos e depois, aos 26,4 anos, em média. Averiguou-se que os sintomas de estalido ou dor, ou os sinais de estalido e crepitação nos adolescentes não puderam ser associados à forma craniofacial. Os sinais de estalido nos adultos foram característicos de indivíduos com uma diminuição do comprimento maxilar e da mandíbula diagonalmente, enquanto os sinais de crepitação na mesma faixa etária relacionaram-se a indivíduos com diminuição de comprimento maxilar e de corpo mandibular, além de redução da base do crânio e faringe.

Nesse mesmo ano, CONTI et al. $^{18}$ realizaram um estudo epidemiológico da prevalência de sinais e sintomas de DTM em 310 estudantes pré-universitários e universitários da cidade de Bauru. A média de idade para o grupo pré-universitário foi de 18,4 anos e de 21 anos para o grupo universitário, sendo $51,6 \%$ pertencentes ao gênero feminino e 48,3\% ao gênero masculino. Foi realizado exame clínico das condições oclusais, palpação muscular e um questionário anamnésico. Concluiu-se que as condições oclusais apresentavam pequena participação na etiologia das DTMs, diferentemente dos hábitos parafuncionais e do estresse, que demonstraram grande associação com sinais e sintomas de DTM. Os sintomas freqüentemente relatados foram os ruídos articulares $(20,9 \%)$ e as dores de cabeça $(16,1 \%)$. Um total de $0,65 \%$ dos indivíduos apresentou sintomas severos de DTM, 5,81\% demonstraram sintomas moderados e $34,84 \%$, sintomas leves. Não se observou uma relação entre a realização prévia de tratamento ortodôntico e a presença ou severidade de DTM.

A associação entre o tratamento ortodôntico e os desarranjos internos da ATM foi estudada por KATZBERG et al. ${ }^{54}$ (1996). As relações 
entre côndilo, disco e fossa articular foram avaliadas por meio de ressonância magnética, em 76 voluntários assintomáticos e em 102 pacientes com DTM. Utilizou-se, como critério de inclusão na amostra de voluntários, a ausência de dor na ATM ou ao seu redor, estalido e história de travamento mandibular. Os pacientes foram indagados se tinham se submetido a tratamento ortodôntico. Os resultados indicaram uma prevalência de $33 \%$ de deslocamento de disco nos voluntários e de $77 \%$ nos pacientes de DTM. Não foi possível correlacionar o tratamento ortodôntico aos desarranjos internos da ATM, ou seja, o deslocamento de disco estava presente indistintamente nos pacientes e voluntários, tratados ou não ortodonticamente.

Em 1997, MCNAMARA JUNIOR; TÜRP ${ }^{70}$ revisaram a relação do tratamento ortodôntico com as DTMs. Foram abordadas as diferenças entre aparelhos fixos e removíveis, a influência do tratamento ortodôntico, com ou sem extrações, e ainda se questionou o papel da ortodontia na cura ou prevenção das DTMs. Os autores concluíram que o tratamento ortodôntico, independente do tipo de mecânica e da realização de extrações, não aumenta os riscos do indivíduo desenvolver DTM no futuro. Mas, apesar de não causar DTM, não existem evidências convincentes de que o tratamento ortodôntico pode curar essas disfunções.

Ainda em 1997, HENRIKSON; EKBERG; NILNER ${ }^{45}$ compararam os sinais e sintomas de DTM em dois grupos de jovens do gênero feminino. O primeiro grupo era composto de 123 jovens com má oclusão de Classe II e o outro grupo era composto de 60 jovens com oclusão normal, todas entre 11 e 15 anos de idade. As jovens responderam a um questionário sobre sintomas de DTM e duas escalas, uma verbal e outra visual, sobre a severidade dos sintomas e grau de ansiedade. Além desse questionário, as jovens se submeteram a um exame clínico de sinais de DTM, realizado por dois examinadores treinados. A prevalência de dor de cabeça, estalidos na ATM, bruxismo e apertamento foi maior nas jovens com má oclusão, em comparação com as jovens com oclusão normal. 
Constatou-se uma relação entre hábitos parafuncionais e má oclusão. Várias características oclusais como trespasse horizontal aumentado, mordida aberta anterior, poucos contatos oclusais, desvio lateral entre RC e $\mathrm{MIH}$, apinhamentos e interferências no lado de não trabalho aumentaram as chances de ocorrência de sinais e sintomas de DTM. Concluiu-se que indivíduos com oclusão normal têm menos chances de apresentar sinais e sintomas de DTM, enquanto algumas características oclusais freqüentemente encontradas na Classe II aumentam as possibilidades de sinais e sintomas de DTM.

Em 1998, LAGERSTRÖM; EGERMARK; CARLSSON ${ }^{61}$ estudaram a prevalência de sinais e sintomas de DTM em dois grupos de pacientes tratados ortodonticamente, um por especialistas e outro, por clínicos gerais, e ainda compararam com um grupo controle não tratado. Para isto, empregaram um questionário anamnésico e um exame clínico a respeito das funções do aparelho mastigatório. $\mathrm{O}$ índice clínico de disfunção de Helkimo foi utilizado, porém com redução no número de músculos palpados. Obtiveram como resultados uma similaridade na prevalência de sintomas entre os grupos, sendo que $10 \%$ de toda a amostra relataram freqüentes dores de cabeça. Os sinais de DTM, como ruídos articulares, sensibilidade nas articulações e nos músculos acometeram mais o gênero feminino. De acordo com os resultados, o tratamento ortodôntico não aumenta os riscos de desenvolver sinais e sintomas de DTM.

Em 1999, HENRIKSON; NILNER; KUROL ${ }^{47}$ estimaram a prevalência de sinais e sintomas de DTM antes, durante e após o tratamento ortodôntico em 65 jovens do gênero feminino, com idade média de 12,8 anos, no início do estudo. Das 65 jovens, 30 foram tratadas sem extração e 35 com extração. A prevalência de sinais e sintomas foi medida com um questionário anamnésico e avaliação clínica em quatro períodos distintos: antes, durante e após o tratamento ortodôntico, e um ano após, a terceira avaliação. A prevalência de estalido na ATM (pelo menos uma vez por semana) antes do tratamento foi de $20 \%$, diminuindo para $15 \%$ durante 
e após o tratamento. Contatou-se uma diminuição na prevalência de sensibilidade muscular à palpação e também uma redução dos sintomas relatados durante e após o tratamento ortodôntico. Considerando o tratamento realizado com ou sem extrações, não se encontraram diferenças quanto à prevalência de estalidos. De acordo com os autores, o tratamento ortodôntico não aumentou os riscos de sinais e sintomas de DTM.

HENRIKSON; NILNER; KUROL ${ }^{46}$ (2000) avaliaram a presença de sinais de DTM em 65 jovens com má oclusão de Classe II, tratadas ortodonticamente e compararam com 58 jovens com a mesma má oclusão, não tratadas, e 60 jovens com oclusão normal. Os três grupos foram clinicamente inspecionados quanto à mobilidade mandibular, dor nos movimentos mandibulares, presença de estalidos na ATM, dor à palpação da ATM e músculos mastigatórios. Um exame das características oclusais ainda foi realizado. Duas avaliações foram executadas para toda a amostra, antes do tratamento ortodôntico, e dois anos após. A realização de tratamento ortodôntico fixo não aumentou os riscos de sinais de DTM. Ao contrário, as jovens com sinais de DTM de origem muscular mostraram se beneficiar com o tratamento nesses dois anos. A presença de estalidos na ATM aumentou em dois anos nos três grupos, sendo que o grupo de oclusão normal apresentou menos sinais de DTM em relação aos outros grupos. Constatou-se que o tipo de má oclusão pode desempenhar um papel como fator contribuinte no desenvolvimento de disfunção mandibular, embora esta influência seja difícil de quantificar e predizer.

Utilizando-se da mesma amostra do trabalho acima, HENRIKSON; NILNER ${ }^{44}$, nesse mesmo ano, compararam os sintomas de DTM nos três grupos. As jovens responderam a um questionário a respeito de sintomas de DTM e dor de cabeça, e uma escala verbal foi empregada para classificar a severidade dos sintomas e da dor de cabeça. A presença de estalidos na ATM aumentou nos três grupos, no período de dois anos. Em relação à prevalência de dor de cabeça, ocorreu um ligeiro aumento no grupo não tratado e no grupo com oclusão normal, e uma pequena 
diminuição no grupo em tratamento. Em conclusão, o grupo tratado apresentou menos sintomas de DTM após o tratamento do que antes, enquanto os indivíduos com má oclusão não tratados mostraram um aumento desses sintomas. Segundo os autores, essa diferença poderia ser explicada pela melhora e estabilidade da oclusão. Notou-se, também, a baixa prevalência de sintomas de DTM apresentada pelo grupo com oclusão normal, principalmente quando comparado ao grupo com má oclusão não tratado.

Em 2002, KIM; GRABER; VIANA ${ }^{57}$ conduziram uma rica revisão literária a respeito da relação entre o tratamento ortodôntico e as DTMs. Os artigos selecionados e publicados em inglês apresentavam metodologia apropriada e utilizavam grupos-controle. Apesar dos dados obtidos nos artigos não terem sido tratados estatisticamente, devido ao grau de heterogeneidade, nenhum desses trabalhos realmente indicou maior prevalência de sinais e sintomas de DTM em pacientes tratados ortodonticamente, com exceção de dois trabalhos relacionando a presença de estalidos e sensibilidade à palpação nas ATMs. Segundo os autores, esses dados devem ser considerados com cautela devido à baixa confiabilidade das técnicas de palpação e de inspeção de ruídos articulares.

Também em 2002, CELIC; JEROLIMOV; PANDURIC ${ }^{12}$ estudaram a influência de fatores oclusais e hábitos parafuncionais na prevalência de sinais e sintomas de DTM. Para isso utilizaram uma amostra de 230 jovens, com idades entre 19 e 28 anos, que procuravam tratamento odontológico. Esses indivíduos foram examinados para a detecção de sinais de DTM, como dor ou estalido nas ATMs e sensibilidade muscular. O exame clínico também constou de avaliação oclusal, em que fatores como a relação sagital e transversal dos arcos dentários, a presença de desvios de $\mathrm{RC}$ para MIH e interferências oclusais foram mensurados. Um questionário anamnésico de sintomas de DTM foi respondido pelos participantes dessa amostra. Dos 230 jovens, 38\% relataram a presença de, pelo menos, um sintoma de DTM, e 45\% apresentavam, pelo menos, um sinal. A presença 
de estalidos nas ATMs foi detectada em $40 \%$ da amostra. Alguns fatores oclusais foram associados à prevalência de DTM, como a relação sagital entre os arcos, a presença de mordida cruzada, contatos oclusais na posição retrusiva, interferências no lado de não trabalho, desvios da linha média $\geq 2 \mathrm{~mm}$ e trespasse horizontal $\geq 5 \mathrm{~mm}$. Esses fatores apresentaram uma relação com a presença de DTM, porém essa associação foi baixa, apesar de estatisticamente significante.

Em 2003, CONTI et al. $^{16}$ avaliaram a prevalência de DTM e sua relação com o tratamento ortodôntico, utilizando uma amostra de 200 pacientes divididos em grupos de acordo com o tipo de má oclusão, Classe I ou Classe II e a realização ou não de tratamento ortodôntico. Os indivíduos da amostra que não haviam sido tratados apresentavam idade média de 12,8 anos, e o grupo tratado, de 16,5 anos. Todos eles responderam a um questionário anamnésico contendo questões sobre os sintomas mais freqüentes de disfunção, tornando possível a classificação dos indivíduos de acordo com a presença e severidade de DTM. Um exame de palpação dos músculos mastigatórios e das ATMs e inspeção dos movimentos mandibulares também foram realizados. De acordo com o questionário anamnésico, $34 \%$ da amostra foram classificados com disfunção leve e apenas 3,5\% com disfunção moderada. A presença e severidade de disfunção não foram associadas à realização de tratamento ortodôntico, com ou sem extrações, e nem ao tipo de mecânica empregada.

Nesse mesmo ano, VALLE-COROTTI et al. ${ }^{124}$ pesquisaram a relação entre os aspectos oclusais e as DTMs, utilizando a mesma amostra do trabalho acima. Dentre as variáveis oclusais morfológicas e funcionais estudadas estão: número de contatos na posição de $\mathrm{MIH}$, discrepância de $\mathrm{RC}$ e $\mathrm{MIH}$, contatos do lado de não-trabalho, tipo de guia lateral, presença de guia anterior, presença de facetas de desgaste, mordida cruzada posterior, trespasse horizontal e vertical, e ainda a realização de ajuste oclusal. De acordo com os resultados, a única variável oclusal que apresentou associação estatisticamente significante com a presença de 
DTM foi a mordida aberta anterior; portanto, os autores concluíram que a oclusão não pode ser considerada isoladamente como fator etiológico de DTM.

\section{2- Protrusão mandibular ortopédica e Disfunção Temporomandibular}

A possível relação entre a posição condilar, o tratamento ortodôntico-ortopédico e as Disfunções Temporomandibulares têm chamado a atenção de pesquisadores já há algum tempo. Considerado como terapia das desordens da ATM por alguns e como fator etiológico contribuinte por outros, a protrusão mandibular tem sido largamente utilizada em nossos dias.

Com o objetivo de estimular o crescimento na região dos côndilos e fossa mandibular, tal procedimento pode ser utilizado como terapia de pacientes Classe II, divisão 1, de origem esquelética, causada pela deficiência mandibular.

Devido à falta de unanimidade na literatura pertinente aos efeitos da protrusão mandibular na articulação temporomandibular, faz-se necessário elucidar a real participação dessa modalidade de tratamento ortodôntico na etiologia das Disfunções Temporomandibulares. O conhecimento dos efeitos dessa terapia adquire papel importante, tanto no diagnóstico destas desordens, como para fins legais.

Em 1971, STOCKLI ${ }^{120}$ propôs-se a desvendar a capacidade adaptativa da mandíbula no período de crescimento, quando submetida a tratamento ortopédico funcional, utilizando 8 macacos (Macaca Irus) em fase de crescimento. De acordo com seu trabalho, observou-se um grau de adaptação em 25 dias, sendo que a nova posição mandibular não apresentava recidiva mesmo com 90 dias após a remoção do aparelho, 
quando este foi utilizado por um período de 180 dias. Não foram detectadas alterações histopatológicas.

A capacidade adaptativa histológica da ATM foi estudada por McNAMARA JUNIOR; CARLSON ${ }^{69}$, em 1979. Foram utilizados 28 animais (Macaca Mulatta), divididos em 14 com protrusão mandibular e 14 do grupo controle, sem nenhum tratamento. Os animais foram sacrificados entre duas a 24 semanas após a instalação dos aparelhos. Foram analisadas as respostas da ATM em caráter quantitativo e qualitativo. A adaptação da ATM foi expressa pelas alterações nas camadas de crescimento da cartilagem condilar, mostrando-se elas evidentes a partir da segunda semana, atingindo o seu pico entre quatro e seis semanas. Essas respostas adaptativas foram observadas na borda posterior e póstero-superior do côndilo. Os resultados mostraram que a ATM tem alta capacidade adaptativa em resposta a alterações biofísicas e químicas durante 0 crescimento.

Um estudo similar foi concluído por MCNAMARA JUNIOR; HINTON; HOFFMAN ${ }^{71}$, em 1982; dessa vez, a capacidade adaptativa da ATM avaliada em animais após o período de crescimento. Das 12 macacas (Rhesus) do estudo, apenas seis exibiram respostas qualitativas semelhantes aos animais jovens do estudo anterior, sendo que essas respostas eram quantitativamente inferiores. De acordo com os autores, a adaptação da ATM ocorre mesmo em animais adultos, porém essas respostas são variáveis e limitadas.

Os efeitos induzidos pela protrusão mandibular que causam o deslocamento da mandíbula não se atribuem apenas a um crescimento maior e a uma mudança na direção de crescimento do côndilo, mas também a remodelação que ocorre na fossa mandibular. Esses efeitos foram encontrados por BIRBEBAEK; MELSEN; TERP ${ }^{7}$, em 1984, baseados num estudo com 23 crianças submetidas a tratamento com aparelho ortopédico, e que receberam implantes metálicos nos maxilares. A avaliação dos dados foi realizada em radiografias antes e após 10 meses de tratamento. 
Em 1985, SCHNEIDERMAN; CARLSON ${ }^{113}$ também encontraram remodelação condilar em estudo radiográfico realizado com macacos e afirmaram que a adaptação da ATM pode ocorrer em animais adultos, dependendo da presença ou não de tecido conjuntivo nas superfícies da articulação.

Nesse mesmo ano, PANCHERZ ${ }^{84}$ avaliou os efeitos do uso de um aparelho ortopédico, o Herbst, em 22 pacientes com má oclusão de Classe II, divisão 1, que se encontravam em fase de crescimento. De acordo com seus achados, o número de pacientes com sensibilidade à palpação muscular dobrou nos três primeiros meses de uso do aparelho. Entretanto, depois da remoção do aparelho, a maioria dos sintomas desapareceu e o número de pacientes com sintomas passou a ser igual ao do início do tratamento.

O emprego de aparelhos ortopédicos no tratamento de pacientes com DTM foi divulgado por WILLIAMSON ${ }^{137}$, em 1986. Uma paciente de 20 anos de idade que apresentava dor, estalido e limitação de abertura bucal foi tratada com aparelho ortopédico. Essa terapia proporcionou um avanço mandibular e um alívio dos sintomas da paciente.

Outros autores que indicaram o emprego de aparelhos ortopédicos no tratamento de pacientes com DTM foram GRABER; NEWMAN $^{34}$, em 1987. De acordo com os autores, essa indicação também é válida para pacientes adultos, creditando ao Bionator um efeito de relaxamento muscular quando utilizado para dormir.

MCNAMARA JUNIOR; BRYAN ${ }^{68}$ (1987), controlaram cefalometricamente 11 macacos (Rhesus) que utilizaram aparelhos protrusivos, para verificar a resposta mandibular e fazer a comparação com um grupo controle de 12 animais. Demonstrou-se que os animais do grupo com aparelho apresentaram um crescimento de cinco a seis $\mathrm{mm}$ a mais que os do grupo controle, contrariando a hipótese de que a mandíbula apresenta um crescimento determinado geneticamente. 
Ainda em 1987, WITZIG; SPAHL ${ }^{139}$ detectaram que, com o uso do Bionator, a mandíbula é abaixada, contribuindo para uma descompressão da ATM e prevenindo os problemas de artrose. A utilização desse aparelho ainda elimina a dor e o desconforto, colaborando no tratamento de pacientes com disfunção da ATM. Os autores ainda afirmam que a nova posição mandibular deve ser estabilizada com os desgastes seletivos realizados no acrílico do aparelho, possibilitando, assim, a intercuspidação dos dentes posteriores, e que essa nova posição mandibular vai ser compensada com o crescimento do côndilo.

Em 1988, OWEN ${ }^{82}$ relatou um estudo sobre o emprego do Bionator em pacientes que não respondiam bem à terapia com placas miorrelaxantes. O protocolo utilizado sugeria o avanço mandibular apenas nos pacientes com deslocamento anterior do disco. Apesar desse aparelho funcionar bem para muitos pacientes, em outro trabalho publicado nesse mesmo ano, OWEN relatou um posicionamento posterior de côndilos mesmo em pacientes submetidos a essa terapia. Quando os aparelhos ortopédicos funcionais eram utilizados em pacientes com estalido recíproco, 2 a $3 \%$ dos pacientes ainda apresentavam o estalido após o término do tratamento.

Com o objetivo de relacionar a má oclusão ao posicionamento côndilo-disco-fossa articular, RONQUILLO et al. ${ }^{103}$ (1988) avaliaram 170 ATM de 143 pacientes com sinais e sintomas de DTM. A má oclusão foi avaliada medindo-se os trespasses horizontal e vertical, clinicamente. As radiografias e artrografias utilizadas para avaliar a relação côndilo-fossa e 0 posicionamento do disco articular foram obtidas com os dentes em oclusão cêntrica. O tipo de má oclusão predominante na amostra foi a Classe I. Não se encontrou relação entre o grau de sobremordida, o posicionamento côndilo-fossa e achados artrográficos. O deslocamento do disco sem redução foi relacionado à posteriorização do côndilo e ao aumento do trespasse vertical. De acordo com os autores, os parâmetros oclusais não podem ser associados à sintomatologia das DTMs. 
OP HEIJ; CALLAERT; OPDEBEECK ${ }^{80}$, em 1989, compararam os efeitos do Bionator quando este era construído em máxima propulsão funcional e com os incisivos em topo a topo. Segundo os resultados obtidos com a utilização de radiografias antes e um ano pós-tratamento, a natureza e magnitude dos efeitos do tratamento diferem, significantemente, dependendo do grau de protrusão. O aumento do avanço mandibular, além da posição de topo a topo, não aumenta o crescimento do ramo, mas tornase mais efetivo na correção da relação sagital, provavelmente devido ao maior abaixamento do côndilo. Esses resultados demonstraram um dimorfismo sexual, pois os efeitos do tratamento foram mais significantes nos meninos, estes comparados com as meninas do grupo de maior propulsão funcional. A restrição de crescimento maxilar também foi avaliada, e o grupo com avanço até a posição de topo exibiu melhores resultados.

Em 1990, MAMANDRAS; ALLEN ${ }^{67}$ realizaram um estudo comparando dois grupos de 20 pacientes que se submeteram à terapia com Bionator, em condições similares de quantidade de avanço, tempo de tratamento e previsão do potencial de crescimento. Os grupos foram definidos de acordo com o sucesso no tratamento, sendo um grupo com avanço de $3,5 \mathrm{~mm}$ ou mais no pogônio e o outro grupo com avanço menor que $3 \mathrm{~mm}$. Os autores registraram que os pacientes de melhor resposta ao tratamento apresentavam um crescimento atrasado da mandíbula antes do tratamento, e o aparelho ortopédico eliminava os fatores que implicavam nesse atraso, favorecendo o crescimento mandibular. Concluíram que os indivíduos que exibiam uma mandíbula menor tinham mais chances de se beneficiar com a utilização de aparelhos ortopédicos.

De acordo com um estudo realizado nesse mesmo ano por WARD; BEHRENTS; GOLDBERG ${ }^{131}$, a pressão do fluído sinovial após a protrusão mandibular aumenta, mas retorna em duas horas ao nível normal, enquanto na situação de retrusão mandibular esse aumento da pressão retorna apenas parcialmente ao nível normal. 
THOMPSON $^{122}$, em 1994, avaliou o crescimento condilar de pacientes durante o tratamento ortodôntico e concluiu que tanto nos casos em que ocorreu um crescimento evidente, como nos casos em que quase não se observou crescimento, as chances de desencadear DTM eram as mesmas. Isto porque quando não ocorre crescimento no côndilo durante a movimentação dentária, o espaço funcional livre é invadido e ocorre uma rotação mandibular para trás e para baixo, podendo ocasionar estalidos e outros sintomas na ATM. Nos casos em que a movimentação dentária não invade o espaço funcional livre e ocorre crescimento condilar - e mesmo assim observa-se a presença de estalidos -, pode ser que a rapidez na movimentação dentária tenha impedido a compensação.

A alteração na função da ATM pode estimular uma alteração na sua forma. Essa conclusão de CLARK; GRABER ${ }^{14}$, em 1995, foi baseada na utilização de aparelhos ortopédicos reposicionadores da mandíbula durante a fase de crescimento. Ao autores sugerem o emprego do aparelho "Twin block" como alternativa de tratamento para pacientes com DTM, devido ao deslocamento anterior do disco. Com essa terapia, a mandíbula é reposicionada para anterior, podendo ocasionar a recaptura do disco articular, aliviando o processo de dor na ATM.

Nesse mesmo ano, KEELING et al. ${ }^{56}$ realizaram um estudo comparando a presença de sinais e sintomas de DTM em 191 pacientes Classe II divididos em três grupos, sendo um grupo controle e os outros dois tratados precocemente com Bionator ou com aparelho Extrabucal. De acordo com os resultados, a probabilidade de um indivíduo apresentar dor na articulação era 2,3 vezes maior para os indivíduos que já apresentavam essa dor previamente ao tratamento; 2,4 vezes maior para o grupo controle e grupo do Extrabucal quando comparados aos do grupo tratados com Bionator; e 2,3 vezes maior para os indivíduos classificados com má oclusão de Classe II moderada ou severa (maior que $1 / 2$ cúspide). Com relação aos indivíduos que já apresentavam a dor articular no início, a chance dos mesmos apresentarem a dor após o tratamento era 7 vezes maior para o 
grupo controle e o grupo do aparelho Extrabucal, comparados com o grupo do Bionator.

Em 1996, com o intuito de averiguar a adaptação muscular devido à protrusão mandibular, SFONDRINI et al. ${ }^{116}$ realizaram um estudo com animais. Os animais de escolha foram ratos divididos em grupo experimental e dois grupos controle. O grupo experimental foi mantido com aparelho de protrusão mandibular, sendo alimentado com dieta líquida por um período de 20 dias. Após esse período, os animais foram sacrificados, e as fibras de três músculos com funções diferentes foram estudadas (músculos temporal, digástrico e masseter) e comparadas às dos grupos controle. De acordo com os resultados, os autores concluíram que os músculos da mastigação são capazes de se adaptar facilmente a diferentes demandas funcionais. Essa plasticidade muscular ocorre por uma alteração na estrutura das fibras musculares, aumentando o número de fibras resistente à fadiga e diminuindo as fibras responsáveis pela fadiga muscular.

Em 1999, PANCHERZ; RUF; THOMALSKE-FAUBERT ${ }^{85}$ estudaram o posicionamento do disco articular em relação ao côndilo em pacientes tratados com avanço mandibular, utilizando o aparelho de Herbst. As variações do disco foram mensuradas por meio de ressonância magnética das ATMs, obtidas de uma amostra com 15 pacientes Classe II tratados até uma relação dentária de Classe I. As imagens da ATM foram efetuadas em 5 fases distintas: antes do tratamento, logo após a colocação dos aparelhos, com 3 e 7 meses de tratamento, na remoção do aparelho. Os discos articulares praticamente retornaram à posição original prévia ao tratamento, assim como o posicionamento final dos côndilos em relação às fossas articulares regrediu aos valores iniciais.

RUF; PANCHERZ ${ }^{104}$, em 2000, acompanharam 62 pacientes com má oclusão de Classe II, tratados com o aparelho Herbst, com o intuito de verificar quais os riscos dessa terapia nas articulações. A avaliação constou de exame clínico e obtenção de imagens de ressonância magnética das ATMs. Durante o tratamento, que durou, em média, sete meses, foi 
detectada uma capsulite temporária da porção inferior da região retrodiscal, que não se manteve em todo o período de avaliação, até um ano póstratamento. Não foram detectadas sintomatologia muscular e alterações no posicionamento dos discos em pacientes que os apresentavam fisiologicamente localizados antes do tratamento. Essa terapia contribuiu no posicionamento dos discos nos casos em que esses se apresentavam parcialmente deslocados ao início, porém o tratamento não resultou em melhora nos casos de deslocamento total do disco. Os autores ressaltaram que, a curto prazo, a terapia com o Herbst não provoca efeitos deletérios nas articulações.

Nesse mesmo ano, FREITAS et al. ${ }^{30}$ realizaram trabalho de revisão da literatura considerando o emprego do Bionator e sua relação com as DTMs. Os autores concluíram que a utilização de aparelhos protrusivos como terapia ortopédica na correção das más oclusões de Classe II, não aumenta os riscos de desenvolvimento das DTMs. Relataram ainda que, a ausência de participação desta terapia na etiologia das DTMs também não indica o emprego destes aparelhos no tratamento de pacientes com desordens intra-articulares, pois a adoção dessa modalidade terapêutica não se baseia em achados científicos que comprovem sua eficácia.

No ano seguinte, WATTED; WITT; KENN ${ }^{132}$ avaliaram a relação côndilo-disco e a concentricidade condilar em uma amostra de 15 pacientes Classe II submetidos à terapia de avanço mandibular ortopédico. O aparelho de escolha foi uma combinação do Bionator com tração extrabucal e mais a incorporação de elásticos para prevenir o deslocamento do aparelho no arco inferior, durante o sono. Os pacientes foram tratados durante um ano, sendo que a severidade da má oclusão demandava um avanço de $6 \mathrm{~mm}$, no mínimo. Imagens das ATMs efetuadas com o aparelho de ressonância magnética foram tomadas desses pacientes e de um grupo controle não tratado. Tanto a morfologia como a posição condilar foram consideradas normais ao final do tratamento, bem como a relação côndilodisco. A explicação para esses resultados é baseada na remodelação e 
adaptação óssea e muscular que ocorrem com a terapia de avanço mandibular.

Ainda em 2001, RABIE at al. ${ }^{99}$ conduziram um estudo experimental para averiguar os efeitos na fossa mandibular, em resposta ao avanço mandibular induzido. Para tanto, 100 fêmeas de ratos foram divididas em 2 grupos, 75 sendo parte do grupo experimental e 25, parte do grupo controle. Esses animais foram sacrificados após 3, 7, 14, 21 e 30 dias da instalação de um aparelho propulsor mandibular. Nos animais do grupo experimental, a formação óssea aumentou significantemente do $7^{0}$ para 0 $30^{\underline{0}}$ dia, comparados com os animais do grupo controle. As células osseoprogenitoras se dispuseram na direção das fibras posteriores do disco articular, resultando em formação óssea na fossa mandibular dos animais que receberam o dispositivo de avanço mandibular.

Em 2002, RUF; WÜSTEN; PANCHERZ ${ }^{105}$ avaliaram os efeitos na articulação temporomandibular decorrentes do tratamento com ativador. A amostra constituiu-se de 30 pacientes com má oclusão de Classe II, divididos de acordo com o gênero (9 do gênero feminino e 21 do masculino), com idade média inicial de 11,4 anos. Utilizaram, para isso, o recurso de imagens por ressonância magnética da ATM, realizada com a boca fechada antes e após um ano de tratamento, com o ativador e exame clínico, para verificar a presença de dor na articulação. Os autores relataram uma melhora na relação sagital dos arcos dentários durante o período de tratamento, porém uma relação de Classe I não pode ser obtida em todos os pacientes. Relataram, também, que o tratamento com o ativador não alterou um pré-posicionamento fisiológico entre côndilo-fossa, entretanto essa terapia não contribuiu na recaptura dos discos deslocados para anterior. A presença de capsulite subclínica na região posterior do disco foi um achado relevante nesse estudo.

Também em 2002, HIYAMA et al. ${ }^{48}$ se propuseram a verificar os efeitos eletromiográficos dos músculos masseter e suprahioideo em pacientes submetidos a terapia com o aparelho Bionator. A amostra constou 
de 10 indivíduos do gênero masculino, de nacionalidade japonesa, com média de idade de 26,3 anos. O Bionator foi construído com um avanço mandibular até a posição de topo a topo, com uma espessura do acrílico de $2 \mathrm{~mm}$ na região dos incisivos. Os dados eletromiográficos foram obtidos em um único momento, antes e após a inserção do aparelho, durante uma noite de sono. O número de eventos acima de $40 \%$ da máxima contração voluntária nesses músculos diminuiu com a inserção do Bionator, porém essas alterações não foram estatisticamente significantes.

Com o intuito de averiguar o crescimento da cartilagem condilar após avanço mandibular assimétrico, FUENTES et al. ${ }^{31}$ (2003) realizaram uma pesquisa com animais. Os animais escolhidos foram 39 ratos, em cada um introduzido um dispositivo de avanço mandibular para o lado direito. Esses animais foram sacrificados após 3, 7 e 14 dias da instalação dos aparelhos. Para efeito de comparação, uma amostra controle com ratos pareados pela idade também foi avaliada. Um aumento na espessura da cartilagem condilar foi observado no lado da protrusão, ao contrário do lado da não protrusão, onde ocorreu uma diminuição dessa cartilagem. Baseado nesses resultados, os autores concluíram que nos casos de mordida cruzada posterior não tratados um crescimento diferencial da cartilagem condilar pode resultar em assimetrias esqueléticas.

\section{3- Posição condilar}

O posicionamento condilar dentro da fossa mandibular, assim como os métodos de imagem da ATM, têm sido motivo de vários estudos. Alguns autores relataram a associação das relações não concêntricas côndilo-fossa à função anormal da $\mathrm{ATM}^{96}$ assim como outros relacionaram a simetria bilateral do côndilo à ausência de sintomas clínicos em adultos ${ }^{75}$. Entretanto, o papel da posição condilar na etiologia das DTMs ainda permanece controvertido na literatura. 
Ao estudar técnicas para radiografar as ATMs, SMITH; HARRIS $^{118}$, em 1970, destacaram as radiografias transcranianas (TRs) como capazes de confirmar diagnóstico de restrição do movimento condilar do lado afetado, onde houver presença de espasmo e dor muscular. Relataram que as tomografias e radiografias panorâmicas podem evidenciar as deformidades do côndilo, assim como as radiografias póstero-anterior (PA) e as submento-verticais, sendo as duas últimas também capazes de visualizar hiperplasias condilares. Os autores concluíram que, as radiografias, por melhor que sejam, são instrumentos utilizados com a finalidade de confirmação de diagnóstico clínico.

WILKIE; HURST; MITCHELL ${ }^{134}$, em 1974, compararam radiograficamente a relação côndilo/fossa durante registros maxilomandibulares na $\mathrm{MIH}, \mathrm{RC}$ e estimulação muscular através de um eletrodo de superfície. Para os dois últimos utilizava-se desprogramador oclusal anterior em resina autopolimerizável - Joint Interference Guide (JIG). A amostra foi constituída de 10 indivíduos do gênero masculino, com média de idade de 35 anos. Utilizando-se da fossa mandibular como referência, os côndilos seriam classificados como centralizados quando a mensuração dos espaços articulares anterior e posterior fossem iguais; anteriorizados, quando o espaço articular posterior fosse maior que o anterior; posteriorizados, quando o espaço articular anterior fosse maior que o posterior. Os autores obtiveram como resultados que $70 \%$ dos côndilos estavam centralizados na fossa mandibular. $\mathrm{Na} \mathrm{RC}$ e $\mathrm{MIH}$, os côndilos mostraram-se centralizados em 8 indivíduos. Através do método da estimulação muscular em 5 indivíduos, os côndilos estavam mais para anterior e os outros 5 apresentavam-se centralizados.

Com o intuito de comparar a posição condilar na situação de boca fechada com e sem a utilização de um guia anterior, WILLIAMSON ${ }^{136}$, em 1978, utilizou uma amostra de 20 pacientes assintomáticos. Os indivíduos foram submetidos a duas exposições radiográficas: a primeira, com o fechamento da boca até o primeiro contato dentário, e a segunda, 
com a colocação do guia anterior entre os dentes. As radiografias foram traçadas e algumas estruturas anatômicas utilizadas como referência. Algumas mensurações serviram para se avaliar a posição condilar, como; "espaço anterior": a menor distância entre a superfície anterior do côndilo e o declive posterior da eminência; "espaço posterior": a menor distância entre a superfície posterior do côndilo e a superfície posterior da fossa mandibular; "espaço superior": a menor distância entre a superfície superior do côndilo e o ápice da fossa mandibular. Uma grande variação das posições condilares foi verificada. Com o dispositivo anterior em posição, o côndilo se deslocou nas distâncias superior, anterior e posterior, aproximadamente 0,9mm. Em relação ao espaço articular, as médias foram de 2,2mm para anterior, 2,0mm para posterior e $3,4 \mathrm{~mm}$ para superior. Com a utilização do guia anterior, a maior alteração da posição condilar foi na distância superior.

KUNDERT $^{59}$, em 1979, investigou a confiabilidade na medição da posição condilar por meio de radiografias. Para isso, 11 estudantes da escola de Odontologia de Zurique, sem sinais e sintomas de disfunção, foram selecionados para obtenção de radiografias da ATM. Essas radiografias foram tomadas de maneira padronizada, com dispositivo para fixação da cabeça durante a tomada radiográfica. A primeira exposição foi denominada de posição zero, as exposições subseqüentes efetuadas mediante avanços de $0,2 \mathrm{~mm}$ da mandíbula para frente. Para avaliação dos resultados, um total de 12 dentistas foi dividido em três grupos, de acordo com a experiência quanto à análise radiográfica da ATM. No primeiro grupo, os profissionais apresentavam valiosa experiência. O segundo e terceiro grupos representavam clínicos com boa experiência ou nenhuma com radiografias da ATM, respectivamente. Os melhores resultados foram obtidos das radiografias mais nítidas e dos grupos com mais experiência na interpretação dessas imagens.

MIKHAIL; ROSEN ${ }^{74}$, em 1979, determinaram a correlação entre sinais e sintomas de DTM e o posicionamento do côndilo na fossa mandibular. A amostra foi composta por três grupos: (1) pacientes com 
disfunção, (2) amostra aleatória e (3) pacientes que se submeteram a reabilitações oclusais. O último grupo foi subdividido em (a) pacientes que tinham sinais/sintomas antes da terapia e que tiveram melhora após o tratamento, (b) pacientes sem sinais antes e após tratamento, (c) pacientes que continuaram com os sinais após tratamento e (d) pacientes sem sinais antes da terapia e que apresentaram sintomatologia após tratamento. Os indivíduos foram submetidos a um exame clínico e radiográfico das ATMs, sendo que para obtenção das radiografias utilizou-se um dispositivo para fixar a cabeça. No grupo dos pacientes com disfunção, 88\% tinham assimetria dos espaços articulares, um resultado muito similar aos $89,5 \%$ do grupo de inclusão aleatória, em que apenas $25 \%$ dos pacientes apresentavam sinais e sintomas de DTM. No terceiro grupo, nos pacientes sem melhoras após tratamento, 91\% tinham espaços articulares assimétricos, sendo $72,6 \%$ de posteriorização condilar. A concentricidade condilar não foi freqüente nos grupos estudados, independente dos pacientes apresentarem ou não sinais e sintomas de DTM.

WEINBERG ${ }^{133}$, em 1979, avaliou o papel da posição condilar nas disfunções da ATM em 116 pacientes, dos quais 55 faziam parte do grupo com DTM e 61 do grupo controle. Dos que apresentavam disfunção, $71 \%$ tinham retrusão condilar (40\% unilateral e 31\% bilateral), 18,2\% para anterior, $7,3 \%$ superior e $3,6 \%$ centrados. No grupo controle, $36 \%$ estavam retruídos (21\% unilateral e 14,7\% bilateral), 10\% estavam para superior, $23 \%$ centrados e $31 \%$ para anterior. Observou-se que a retrusão condilar foi vista com bastante freqüência no grupo controle, indicando que, quando se obtém a RC manipulando-se a mandíbula na posição mais posterior, não necessariamente se orienta o côndilo corretamente na fossa, como era comumente pensado.

Com o objetivo de analisar a relação côndilo-fossa com a mandíbula em RC e MIH, ISMAIL; ROKNI ${ }^{52}$, em 1980, selecionaram 40 pacientes. Os critérios de inclusão da amostra foram: má oclusão de Classe I, ausência de interferências oclusais, presença de poucas ou nenhuma 
restauração oclusal, ausência de sinais e sintomas de DTM e saúde dos tecidos periodontais. Foram realizadas 4 exposições radiográficas de cada paciente (duas em RC, com o auxílio de um JIG e duas em MIH). Para assegurar a confiabilidade dos resultados utilizaram-se análises intra e interexaminadores. Na posição de RC, as médias dos valores das mensurações dos espaços articulares esquerdo foram: $2,8 \mathrm{~mm}$ para o superior; $2,4 \mathrm{~mm}$ para o anterior e 1,9mm para o posterior. Esses valores para o lado direito foram 2,7; 2,3 e 1,9mm, respectivamente. Em MIH, o lado esquerdo exibiu valores de 3,0; 2,1 e 2,3 para os espaços superior, anterior e posterior, e o lado direito 2,8; 2,1 e 2,1, respectivamente. De acordo com os resultados, os côndilos estavam posicionados mais posterior e superiormente na posição de RC.

No ano seguinte, CARWELL; McFALL JUNIOR ${ }^{11}$, compararam as posições de RC determinadas pelos métodos guiados do polegar no queixo (MGP) e manipulação bilateral mandibular (MBM) em 10 pacientes. Foram obtidas radiografias transcranianas padronizadas das ATMs e a posição condilar foi determinada por traçados e mensurações diretas nas radiografias, por intermédio de dois observadores treinados, empregando-se o método duplo-cego. Com base nos resultados, não se observou diferença estatisticamente significante nos valores médios para os espaços articulares com os dois métodos de manipulação em RC embora os côndilos tenham se posicionado mais superior e posteriormente na técnica MGP.

MONGINI ${ }^{73}$, em 1981, comparou as alterações condilares determinadas por dois métodos, as radiografias transcranianas e as tomografias laterais. A amostra foi composta de 8 indivíduos do gênero masculino e 22 do feminino, entre 18 e 60 anos. As TRs foram tomadas com o paciente estando em MIH, utilizando-se uma angulação de 22 graus em relação ao plano horizontal e 10 graus em relação ao plano frontal. Tomografias laterais também foram desenvolvidas em 5 a 7 planos, avaliando-se a posição, forma e alterações condilares. Em relação à posição 
e às alterações condilares, estas se mostraram mais evidentes nas tomografias do que nas TRs.

HELLSING; ISBERG-HOLM; MCWILLIAM ${ }^{43}$, em 1983, analisaram as diferenças na posição do côndilo com a mandíbula em RC, determinada pelo método da manipulação manual (MGP) e bimanual guiadas (MBM) com JIG interposto. Um grupo de 15 alunos (10 do gênero masculino e 5 do feminino) da escola de Odontologia de Estocolmo, livres de sinais e sintomas de DTM, constituíram a amostra. Radiografias transcranianas foram realizadas nas duas posições com o dispositivo acrílico interposto. Os resultados não mostraram, radiograficamente, diferenças significativas entre as duas técnicas. Em MBM, 13 côndilos estavam para superior, 14 para inferior e 3 iguais à MGP. Paradoxalmente, 17 côndilos estavam mais para posterior em MBM do que em MGP (posição retruída), enquanto que 13 côndilos estavam mais para anterior, concluindo-se que a denominação de MGP e MBM não são relevantes.

Com o intuito de comparar as imagens da ATM obtidas por meio de TR e tomografias, VAN SICKELS; BIANCO; PIFER ${ }^{125}$, em 1983, examinaram 61 pacientes com queixas de disfunção ou dores na ATM. Esses pacientes preencheram, primeiramente, o formulário sobre a história da doença e foram submetidos a tomadas radiográficas transcranianas das articulações. Após essa avaliação inicial, foi instituído um protocolo de tratamento utilizando-se placas estabilizadoras. Alguns pacientes foram submetidos a tomadas tomográficas e artrotomográficas das ATMs, mediante o insucesso desse protocolo com as placas. Do total, apenas 4 realizaram esse estudo de forma bilateral e 7, unilateralmente. Variações de posição e estruturais do terço lateral do côndilo e da fossa foram visualizadas pelas TRs. Os autores sugeriram que as tomografias e artrotomografias fossem utilizadas como recurso em casos com inconsistência de informações imprescindíveis para a elaboração do plano de tratamento. 
Nesse mesmo ano, HANSSON; HANSSON; PETERSSON ${ }^{37}$ compararam achados clínicos e radiográficos em 259 pacientes com DTM. Os pacientes foram submetidos a um exame para verificação da máxima abertura bucal, presença de deslize de RC para $\mathrm{MIH}$, sensibilidade à palpação dos músculos e ATM, presença de ruídos articulares, perda de suporte dentário na região de pré-molares e molares, e presença de desgastes dentários. Para a obtenção dos dados radiográficos foram empregadas as seguintes técnicas radiográficas: projeção submentovértex, TR e projeção transmaxilar. Tomografias foram tomadas em apenas 30 pacientes. Nas TRs, a posição do côndilo foi avaliada na posição de $\mathrm{MIH}$, sendo classificada como anterior, central, posterior, superior e inferior. Não foi possível identificar em 12 radiografias a posição condilar; contudo, nas 506 ATMs restantes, 128 estavam concêntricas, 81 anteriores, 250 posteriores, 13 superiores e 34 inferiores. Os resultados demonstraram associação entre um posicionamento mais posterior do côndilo e variações na estrutura óssea, perda de suporte dentário e estalido articular. Os autores discutem a confiabilidade dos resultados obtidos pelas radiografias TRs, alegando que a posição posterior do côndilo poderia ser uma conseqüência das variações teciduais ou distorções inerentes à técnica radiográfica.

Em 1985, LIEDBERG; ROHLIN; WESTESSON ${ }^{63}$, estudaram a variação intra e interexaminador da posição condilar em TR e tomografias sagitais (lateral, medial e central) da ATM. Um total de 124 radiografias obtidas de 31 pacientes aleatórios foram avaliadas por 3 examinadores experientes em imagens da ATM. Os examinadores avaliaram as radiografias em duas situações distintas, com intervalo de três meses entre a primeira e a segunda, classificando a posição condilar. A concordância interexaminadores foi entre 69 e 79\%, e a intra-examinadores foi entre 81 e $90 \%$. Uma posição avaliada como posterior por um observador nunca foi considerada como anterior, em outra radiografia por qualquer dos outros dois observadores e vice-versa. Concluíram que as variações e limitações das técnicas radiográficas devem ser consideradas quando a implicação da posição condilar é discutida. 
Nesse mesmo ano, PULLINGER; HOLLENDER ${ }^{93}$ questionaram se as TRs são métodos apropriados de mensuração da posição condilar e se a posição condilar mostrada pelas TRs laterais difere das mostradas pelas tomografias lineares sagitais, registradas da mesma ATM. Foram selecionados 10 pares de tomografias e TRs, tendo-se como critério a clareza da visualização das imagens e ausência de remodelação óssea. A angulação para as tomografias foi de 20 graus posterior e das TRs; de 10 graus posterior e 20 graus cranial. Os métodos de avaliação foram subjetivos, definindo-se como -2 a posição mais retruída, -1 se posterior, 0 se concêntrico, +1 se anterior e +2 se extremamente anterior. Um segundo método de avaliação também foi utilizado, método qualitativo com aplicação da seguinte equação logarítmica para se determinar a posição condilar:

$$
X=\log e \frac{\text { Medida do espaço articular posterior }}{\text { Medida do espaço articular anterior }}
$$

Através das tomografias, os côndilos se mostraram mais para posterior, por meio de análise subjetiva. Nas TRs o côndilo permaneceu concêntrico, utilizando-se os métodos de centralização da fossa e crista da eminência, assim como o método de mensuração linear. Do total, $40 \%$ dos casos foram classificados como concêntricos e 40\% como posteriores, nas tomografias, enquanto que $30 \%$ concêntricos e $50 \%$ posteriores nas TRs; quando o côndilo foi avaliado via mensuração linear de forma subjetiva do espaço articular, que foi o método preferido e recomendado para comparação. A avaliação subjetiva e a mensuração linear expressa pela equação logarítmica foram escolhidas como métodos para representar a posição condilar. Uma concordância completa para posição condilar pela avaliação subjetiva foi determinada em $60 \%$ dos pares de TRs e tomografias. Apesar dos dados serem significativos, as tomografias se mostraram mais confiáveis na precisão dos resultados do que as TRs.

Ainda em 1985, PULLINGER et al. ${ }^{96}$ efetuaram um estudo da posição condilar por meio de tomadas tomográficas das ATMs, em 
indivíduos assintomáticos. A amostra foi composta por 46 jovens, sendo 26 do gênero masculino e 20 do feminino, com média de idade de 24 anos. Esses indivíduos foram examinados e classificados como assintomáticos em relação a desordens mastigatórias, não apresentavam história prévia de tratamento ortodôntico ou ajuste oclusal e também não apresentavam coroas nos molares. Tomografias lineares das ATMs direita e esquerda foram obtidas dos 46 jovens em posição de intercuspidação, e a concentricidade condilar foi mensurada de acordo com o método proposto por PULLINGER; HOLLENDER ${ }^{94}$. A concentricidade condilar foi encontrada em aproximadamente 50 a $65 \%$ dos jovens, com uma grande variabilidade. A distribuição de côndilos não concêntricos foi, significantemente, mais para anterior, nos indivíduos do gênero masculino, e mais para posterior, nos do gênero feminino. Devido à detecção de não concentricidade condilar em pessoas assintomáticas, concluiu-se que não se justifica qualquer forma de tratamento no intuito de se restabelecer a posição condilar.

PULLINGER; HOLLENDER ${ }^{94}$ publicaram em 1986 a fórmula para cálculo da posição condilar idealizada dois anos antes, por meio da seguinte equação:

Espaço articular posterior - espaço articular anterior $\quad X 100 \%$ Espaço articular posterior + espaço articular anterior

Um valor positivo indicaria que o côndilo estaria posicionado para anterior, nulo representaria a concentricidade e um negativo para posterior.

PULLINGER et al. $^{97}$ (1986) estudaram se análises tomográficas ofereceriam diferenças significativas na posição condilar quando pacientes foram avaliados dentro dos subgrupos de diagnóstico das DTMs. A amostra constituiu-se de 106 pacientes com disfunção da ATM e pacientes do grupo controle assintomáticos. Todos foram tratados por um autor (W.K.S) durante 1 ano, examinados e diagnosticados detalhadamente para, posteriormente, serem classificados em um dos três grupos de diagnóstico: mialgia, 
desarranjo interno e artrose ou artrite. Tomografias laterais foram registradas em MIH com 20 graus de angulação posterior. As radiografias foram projetadas num computador com $12.5 \mathrm{X}$ de magnificação, usando-se uma câmera de vídeo conectada ao computador. A posição do côndilo foi determinada baseada na equação descrita por PULLINGER; HOLLENDER ${ }^{94}$. A média da posição foi posterior em todos os grupos de diagnóstico estudados e concêntrico no grupo controle. No grupo de desarranjo, $52,5 \%$ foram posteriores, $40 \%$ concêntricos e $7,5 \%$ anteriores. No grupo da mialgia, $15,8 \%$ foram posteriores, $78,9 \%$ concêntricos e $5,3 \%$ anteriores. Na categoria das artroses, $41,25 \%$ foram posteriores, $38,2 \%$ concêntricos e $20,6 \%$ anteriores. A idade foi um fator significativo na descrição da posição condilar, havendo uma tendência do côndilo se posicionar mais para posterior nos pacientes acima de 45 anos.

Em 1987, PULLINGER et al. ${ }^{98}$ estudaram a relação entre a posição condilar e fatores oclusais em uma amostra de 44 pacientes assintomáticos, sem história de tratamento ortodôntico ou terapias oclusais. A posição condilar foi medida com base em imagens de tomografia da ATM, constatando-se que a ausência de concentricidade dos côndilos era mais comum em pacientes apresentando má oclusão de Classe II, com uma freqüência maior de côndilos anteriorizados em pacientes Classe II, divisão 1. A posição condilar não foi associada a discrepâncias sagitais de $R C e$ $\mathrm{MIH}$, ao grau de sobremordida ou sobressaliência.

No ano seguinte, PRETI; FAVA ${ }^{92}$ realizaram estudo para determinar que técnica poderia ser considerada mais confiável na determinação da posição condilar, analisando-se ainda, a validade das TRs. Para isso, foram selecionados 15 pacientes e 10 crânios secos. As tomadas radiográficas foram obtidas em $\mathrm{MIH}$, utilizando-se um registro interoclusal de silicona. Nos crânios secos foram realizadas impressões com silicona do espaço articular. Na impressão foram colocados pinos como referência do longo eixo da articulação. Essas impressões foram vazadas com gesso e recortadas em fatias de $2 \mathrm{~mm}$ (perpendiculares ao longo eixo da ATM). As 
fatias foram avaliadas por um completo exame radiográfico, que consistiu de exame submentovértex, uma fluoroscopia, duas TRs (uma baseada na radiografia submentovértex e outra na fluoroscopia) e, por fim, executaramse tomografias em camadas perpendiculares ao longo eixo do côndilo. A posição condilar foi julgada por 3 radiologistas, dividindo-a em anterior, central e posterior. O exame radiográfico processou-se da mesma forma em 15 pacientes e foi avaliado da mesma maneira. Concluiu-se que as TRs individualizadas por meio de fluoroscopia podem ser instrumentos úteis para a determinação da posição condilar.

Ainda em 1988, GROSS ${ }^{36}$ avaliou a variação na posição condilar como resultado do aumento da dimensão vertical de oclusão, por meio de radiografias TR. A amostra foi composta por 20 indivíduos assintomáticos, sendo 8 do gênero feminino e 12 do masculino, que foram submetidos a tomadas radiográficas das ATMs em 4 dimensões verticais diferentes. A primeira em $\mathrm{MIH}$, as outras três com o auxílio de um levantamento da mordida em cera, com variação na espessura de 2,5; 5 e 10mm. A posição condilar foi analisada com a sobreposição das imagens radiográficas e, para se quantificar a variação de movimento e de direção do côndilo, foi determinado o ponto superior condilar (PSC). Baseado nos resultados, o deslocamento do PSC foi mais freqüente nas direções para baixo e para frente, sendo as médias de deslocamento do PSC de $1 \mathrm{~mm}$; $1,65 \mathrm{~mm}$ e 2,73mm para os aumentos da dimensão vertical de 2,5; 5 e 10mm respectivamente. Os autores concluíram que devido às significativas alterações da posição condilar se torna difícil atribuir essas diferenças apenas à variação na dimensão vertical. Outros fatores poderiam influenciar esses resultados, como o ângulo de suporte, alterações da morfologia condilar e o eixo de orientação do feixe radiográfico.

GIANELLY ${ }^{32}$, em 1989, efetuou uma revisão de trabalhos relacionados à posição condilar e ATM associados ao tratamento ortodôntico. Com base na avaliação das condições da ATM dos 320 pacientes pertencentes a essas pesquisas, nenhuma diferença foi 
encontrada quando se comparou a ATM desses indivíduos submetidos a tratamento ortodôntico prévio com amostras de grupo controle. Desses 320 pacientes, mais de 90 haviam sido tratados com extração de pré-molares como protocolo de tratamento e, mesmo assim, as condições da ATM foram similares às das pessoas não tratadas ortodonticamente. Esses dados, segundo o autor, confirmam a não participação do tratamento ortodôntico na etiologia das DTM.

Em 1991, TYNDALL et al. $^{123}$ testaram a validade da digitalização da radiografia transcraniana para detecção de alterações posicionais do côndilo mandibular. Essas alterações da posição condilar foram medidas em imagens radiográficas realizadas em laboratório, utilizando-se um posicionador de cabeça e um crânio seco. Os autores concluíram que as alterações posteriores do côndilo podem ser detectadas com a precisão de $0.09 \mathrm{~mm}$ para cada $1 \mathrm{~mm}$ de movimento e de $0.14 \mathrm{~mm}$ para $3 \mathrm{~mm}$ de movimento. Relataram, ainda, que essa técnica apresenta vantagens, pela sua simplicidade, e por não acarretar riscos adicionais para os pacientes quando as radiografias são digitalizadas.

Também em 1991, GIANELLY; ANDERSON; BOFFA ${ }^{33}$ compararam a posição condilar antes e após o tratamento ortodôntico em 79 pacientes tratados sem extração e em 32 tratados com extração. A posição condilar foi avaliada em tomogramas, de acordo com as medidas dos espaços articulares anterior e posterior. O tratamento ortodôntico não alterou o posicionamento condilar, que se manteve estável nos pacientes, para ambos os grupos. Concluiu-se que o risco de retroposicionamento condilar nesse estudo foi menor que $5 \%$, não se relacionando com modalidades terapêuticas específicas.

Ainda em 1991, KUNDINGER et al. ${ }^{60}$ propuseram-se a estudar os efeitos na articulação temporomandibular e musculatura mastigatória após o tratamento ortodôntico envolvendo extração de pré-molares. Com esse intuito, 29 indivíduos com idades entre 15 e 36 anos, tratados ortodonticamente, foram comparados a um grupo controle não tratado, com 
idades entre 21 e 48 anos. Imagens tomográficas das ATMs foram obtidas e a concentricidade condilar medida com o protocolo proposto por PULLINGER; HOLLENDER ${ }^{94}$. Não foram encontradas diferenças significantes a respeito da posição condilar entre o grupo tratado e o grupo controle. Do mesmo modo, em relação à musculatura mastigatória, os exames eletromiográficos também resultaram em dados semelhantes entre os dois grupos. Com base nos resultados os autores não confirmaram a hipótese de que o tratamento ortodôntico realizado com extração de prémolares poderia desencadear danos irreversíveis às articulações e músculos da mastigação.

Os efeitos da extração de pré-molares na posição condilar também foram estudados por LUECKE; JOHNSTON JUNIOR ${ }^{64}$, em 1992. Foram realizadas medições nas telerradiografias de 42 pacientes que se submeteram à terapia ortodôntica fixa, antes e após o tratamento. De acordo com os resultados, apenas $30 \%$ dos pacientes mostraram um deslocamento posterior do côndilo, sendo que o deslocamento mandibular relacionou-se mais às alterações dos dentes em oclusão do que à retração dos incisivos.

Com o objetivo de verificar a participação da retração dos dentes anteriores superiores na posteriorização dos côndilos, ARTUN; HOLLENDER; TRUELOVE ${ }^{4}$ (1992) examinaram clínica e radiograficamente 63 jovens tratadas ortodonticamente. O grupo com má oclusão de Classe II, divisão 1, era composto por 29 jovens tratadas com extração dos primeiros pré-molares superiores, e as outras 34 jovens, com má oclusão de Classe I, foram tratadas sem extração. As pacientes tratadas com extração mostraram uma posição condilar mais posteriorizada, fato justificado pela alta prevalência de côndilos anteriorizados no grupo sem extração.

ALEXANDER; MOORE; DuBOIS ${ }^{3}$ (1993) utilizaram uma amostra de 28 indivíduos do gênero masculino, com idades entre 22 a 35 anos, para estudar a posição do côndilo mandibular. Testaram a confiabilidade das posições condilares de intercuspidação e relação cêntrica 
obtidas em montagem do articulador, e as compararam com as posições condilares em imagens de ressonância magnética. Os resultados do trabalho demonstraram que metade da amostra apresentava concentricidade condilar, que se repetia nas posições de intercuspidação e relação cêntrica obtidas no articulador. Concluíram que a análise das posições mandibulares no articulador é reproduzível, e que o conceito de saúde das ATMs baseado na concentricidade condilar não pode ser confirmado por esse estudo, assim como o de tratar em relação cêntrica como meio de melhorar a relação côndilo-disco.

MUTO et al. ${ }^{76}$, em 1994, propuseram uma investigação para se determinar a posição anatômica do côndilo na máxima abertura bucal e a relação entre a movimentação anterior ou vertical do côndilo na eminência durante a abertura. Foram tomadas TRs de 86 pacientes. O ângulo de suporte foi de 25 graus em relação à região parietal superior. As radiografias foram traçadas e pontos foram desenhados nas estruturas anatômicas, para auxiliar nas mensurações. Os resultados mostraram uma média de abertura de boca e extensão dos movimentos laterais maior nos indivíduos do gênero masculino. Embora a extensão da fossa mandibular esquerda tenha sido semelhante entre os dois gêneros, os valores do lado direito foram maiores no gênero masculino, assim como a profundidade da fossa. $O$ movimento para frente do côndilo foi de aproximadamente $19,4 \mathrm{~mm}$ nos jovens do gênero masculino e $18,2 \mathrm{~mm}$ no feminino. Os autores concluíram que na máxima abertura bucal nenhuma correlação significativa houve entre a profundidade da fossa mandibular e o movimento vertical do côndilo na eminência.

Apesar da importância da posição condilar na ATM ainda não ter sido totalmente esclarecida e a posição normal não ter sido definida, muitos estudos têm sido realizados no sentido de se guiar o côndilo a uma posição cêntrica na fossa mandibular, com o intuito de aliviar sintomas em pacientes com dor orofacial e desarranjo interno da ATM. Assim, REN; ISBERG; WESTESSON ${ }^{100}$, em 1995, verificaram a posição condilar em 34 
articulações de pacientes assintomáticos e sem deslocamento de disco determinado por artrografia, e em 85 ATMs de pacientes com diferentes estágios de desarranjo interno. Nesse estudo, os autores observaram grande variabilidade da posição condilar no grupo normal. Além disso, aproximadamente metade do número de articulações com deslocamento de disco com redução e dois terços das ATMs sem redução apresentaram côndilos posicionados posteriormente. Entretanto, os autores alertam que a posição condilar posterior não pode ser utilizada para diagnóstico de deslocamento de disco devido ao grande número de côndilos posicionados anterior e centralmente em pacientes com desarranjo interno da ATM.

Analisar a associação entre alterações condilares radiográficas e tratamento ortodôntico foi o objetivo de PELTOLA et al. ${ }^{87}$, nesse mesmo ano. Para isso, foram avaliadas radiografias panorâmicas antes e após o tratamento ortodôntico de 625 jovens, com idade média de 11 anos antes do tratamento e 14 anos pós-tratamento. As alterações condilares detectadas radiograficamente foram mais freqüentes em pacientes imediatamente após a fase ativa do tratamento, quando comparados com indivíduos não tratados, embora essas alterações tenham sido clinicamente insignificantes. As alterações condilares foram mais freqüentemente associadas ao tratamento com ativador, independente do fato desses pacientes terem utilizado outros tipos de aparelhos. Essas alterações aumentaram com a idade nos jovens tratados ortodonticamente, provavelmente devido à interpretação radiográfica, aos diferentes tipos de aparelhos e à duração do tratamento.

Ainda em 1995, PELTOLA; KÖNÖNEN; NYSTRÖM ${ }^{86}$ utilizaram 39 pacientes da amostra do trabalho anterior e os compararam com um grupo controle de 39 indivíduos pareados em relação ao gênero e à idade, com o intuito de verificar se as alterações condilares ocorrem mais freqüentemente em pacientes tratados ortodonticamente, e se estas alterações são mantidas ao longo do tempo. Os resultados mostraram que as alterações condilares variaram com a idade, após o tratamento, 
tornando-se, em alguns casos, mais severas. Embora se tenha demonstrado certa associação entre as alterações condilares e as DTMs, os sinais clínicos e os sintomas não acarretaram nenhum problema ou problemas mínimos para os indivíduos.

Em 1996, COHLMIA et al. ${ }^{15}$, avaliaram uma amostra de 232 indivíduos, com o intuito de estudar a relação entre as más oclusões e a morfologia do côndilo e fossa mandibular. Desses 232 pacientes, 95 pertenciam ao gênero masculino e 137 ao feminino, todos portadores de algum tipo de má oclusão (Classe I, II ou III). Foram examinados modelos de gesso, telerradiografias em norma lateral e tomografias desses pacientes, que também foram submetidos a exame clínico dos movimentos mandibulares e inspeção de ruídos articulares. De acordo com os resultados, a média de abertura bucal foi de $46 \mathrm{~mm}$, de lateralidade direita $9,8 \mathrm{~mm}$ e de lateralidade esquerda $10 \mathrm{~mm}$. Somente um paciente relatou sensibilidade na articulação sem palpação. Foram detectados estalidos em 13 ATMs do lado direito e 10 do lado esquerdo. Quando se avaliou a presença de estalidos recíprocos, seus valores foram, respectivamente, 5 e 9. Além desses dados, os espaços articulares superior, anterior e posterior também foram mensurados, assim como a posição condilar, determinada pela equação de PULLINGER; HOLLENDER ${ }^{94}$ fez parte dos resultados. Os indivíduos do gênero masculino apresentaram valores significativamente maiores apenas nos espaços articulares superiores de ambos os lados. A média do espaço articular anterior foi de $2,51 \mathrm{~mm}$ direito e 2,69mm esquerdo, e a média do espaço posterior foi de $2,89 \mathrm{~mm}$ direito e $2,63 \mathrm{~mm}$ esquerdo. Com base nesses achados, os autores afirmaram que o côndilo esquerdo se posicionava mais anterior do que o direito. Quando se relacionaram esses dados de posição condilar aos tipos de má oclusão, os indivíduos classificados com má oclusão de Classe III apresentaram os côndilos mais anteriorizados.

Nesse mesmo ano, TASAKI et al. ${ }^{121}$, utilizando-se de ressonância magnética para identificar deslocamentos de disco articular, 
avaliaram a prevalência dessa condição em pacientes de DTM e em uma população assintomática. Diferentes tipos de deslocamento de disco foram observados, uni ou bilateralmente, em $82 \%$ dos pacientes e em $30 \%$ dos indivíduos assintomáticos. A maior prevalência nos pacientes indica uma associação dessa alteração morfológica com dor e Disfunção Temporomandibular, porém essa alteração foi considerada também comum em uma população assintomática.

Em 1997, MAJOR et al. ${ }^{65}$ verificaram o deslocamento condilar associado ao tratamento ortodôntico com e sem extração de pré-molares em pacientes com má oclusão de Classe I. Para tal, a posição condilar foi medida em tomogramas antes e após o tratamento ortodôntico. Os casos tratados sem extração resultaram em um pequeno, mas estatisticamente, significante aumento do espaço articular anterior. A posição condilar não diferiu quanto ao grupo com ou sem extrações de pré-molares.

EKBERG et al. ${ }^{28}$, em 1998, compararam a relação côndilo/fossa de pacientes com disfunção (capsulites e sinovites) tratados com placas estabilizadoras, e de um grupo controle que utilizou uma placa ortodôntica com grampos sobre os dentes superiores, sem alterar a relação intermaxilar. Foram selecionados 58 pacientes distribuídos aleatoriamente nos dois grupos, que receberam tratamento com as respectivas placas por um período de 10 semanas. Foram realizadas tomografias e radiografias transcranianas desses pacientes, para mensuração da posição condilar. Os pacientes que relataram melhora significativa da sensibilidade dolorosa da ATM com o tratamento receberam um escore com valor "zero", enquanto valores de "5" e "3 a 5" representaram, respectivamente, as condições de piora e insucesso no tratamento. Nos pacientes que relataram melhora no tratamento, houve uma significativa variação da posição condilar no grupo em tratamento quando comparado com o grupo controle, o que explica o maior alívio dos sintomas da disfunção.

WILLIAMS $^{135}$, nesse mesmo ano, estudou a posição condilar pré-tratamento e as variações pós-tratamento por meio de tomografias de 
pacientes com DTM. Na história dos pacientes, fazia parte dos relatos dor nos músculos da mastigação, ruídos articulares, contatos oclusais interferentes e limitação nos movimentos excursivos. Um total de 40 pacientes foi selecionado e submetido a tratamento por meio de placas oclusais e/ou ortodontia (10 com placa, 15 ortodontia e 15 com placa antes da ortodontia). As tomografias foram tomadas em $\mathrm{MIH}$. O segundo registro ocorreu de 1,3 a 13,7 anos pós-tratamento. Os pontos de referência selecionados para verificação da posição condilar foram: (a) o ponto mais inferior da eminência articular, (b) a ponta mais posterior e ápice da fossa mandibular e (c) um ponto no centro da fossa mandibular. Dos 80 côndilos examinados antes do tratamento, 23 estavam para posterior, 3 para anterior e 54 centralizados. Nenhuma variação ocorreu após o tratamento, o que suporta a idéia de que a posição de não concentricidade dos côndilos pode ser normal e, por isso, a posição do côndilo não deve ser o único meio de diagnóstico das desordens intra-articulares.

Em um estudo realizado por BOSCOLO; ALMEIDA; PAGANINI $^{9}$, também em 1998, o posicionamento condilar foi determinado com $\mathrm{O}$ auxílio de radiografias transcranianas corrigidas e tomografias lineares em 50 voluntários, entre 18 e 35 anos. Nesse estudo, os espaços articulares foram obtidos por meio de gabaritos. As médias dos espaços articulares encontradas pelos autores foram de 2,64mm para o espaço articular anterior e 2,26mm para o espaço posterior.

Ainda em 1998, OWEN ${ }^{83}$, examinando pacientes durante a terapia ortodôntica fixa, encontrou alguns pacientes com manifestação de problemas da ATM. Dos 600 pacientes em tratamento apenas 16 desenvolveram um ou mais dos seguintes problemas: aumento de ruídos e dor na ATM, aumento de mioespasmos e alterações degenerativas do côndilo, e ou diminuição dos movimentos mandibulares. A posição condilar posteriorizada foi evidenciada com tomogramas em 93,75\% desses 16 pacientes, independentemente da mecânica empregada no tratamento ortodôntico. 
Objetivando relacionar alterações radiográficas da ATM com a idade e o gênero, PETRIKOVSKY; GRACE ${ }^{89}$ avaliaram uma amostra de 491 jovens, em 1999. A amostra foi dividida em 2 grupos, o primeiro com idades entre 9 e 11 anos (155 do gênero feminino e 96 do masculino) e o segundo grupo entre 12 e 15 anos de idade, com 121 jovens do gênero feminino e 119 do masculino. Como pré-requisito para se iniciar o tratamento ortodôntico, modelos de gesso, fotografias e radiografias foram obtidas, assim como tomografias sagitais corrigidas das ATMs. As imagens da ATM foram tomadas com a boca fechada em oclusão cêntrica e com a boca aberta. Os cortes foram realizados com dois $\mathrm{mm}$ de espessura e se restringiam à região das articulações. O grupo com maior idade apresentou freqüência maior de anormalidades ósseas, principalmente do gênero feminino.

O estudo de BONILLA-ARAGON et al. $^{8}$, nesse mesmo ano, avaliou a posição do côndilo na fossa mandibular como predecessor do deslocamento do disco. Cinqüenta e dois pacientes assintomáticos e 130 sintomáticos foram avaliados por meio de tomografia linear e ressonância magnética bilateral da ATM, para se averiguar deslocamento de disco e posição condilar, utilizando-se medições lineares. Os pacientes sintomáticos apresentavam dor articular havia, pelo menos, seis meses, com ou sem limitação de movimento mandibular ou ruído na articulação. Nesse estudo, os autores encontraram $36,5 \%$ de côndilos anteriorizados, $40,4 \%$ concêntricos e $23,1 \%$ posteriorizados em pacientes assintomáticos. Os mesmos valores para pacientes sintomáticos com articulação normal observada na RM foram 33,3\%, 41,4\%, 25,3\%. Pacientes com deslocamento de disco com redução apresentaram $23,1 \%$ de côndilos anteriorizados, $35,6 \%$ concêntricos e 41,3\% posteriorizados, enquanto pacientes com deslocamento de disco sem redução exibiram valores de $20,3 \%, 31,3 \%$ e 48,4\%, referentes às mesmas posições condilares. Com base nesses resultados, concluiu-se que a posição do côndilo não é um bom indicador da presença ou ausência de deslocamento de disco. 
Em um estudo idealizado por OZAWA et al. ${ }^{81}$, ainda em 1999, a posição condilar foi investigada em 76 ATMs com diferentes estágios de deslocamento de disco. Imagens de ressonância magnética da ATM foram empregadas para se verificar o deslocamento de disco, que foi classificado de acordo com o grau de severidade em uma escala de 1 a 3 . Para avaliação da posição condilar foram realizadas mensurações dos espaços articulares anterior, superior e posterior em tomografias corrigidas. A medida do espaço articular anterior foi significantemente maior para as ATMs classificadas como 1, 2 ou 3, sugerindo um posicionamento posterior do côndilo quando comparadas às articulações sem deslocamento de disco (valor zero). Entretanto, quando o deslocamento de disco se torna severo (3), o espaço posterior tende a aumentar até a uma distância compatível com a das ATMs sem deslocamento de disco, apontando para uma posição condilar mais próxima da normal.

PORTO $^{90}$ avaliou a posição condilar antes e após instalação de próteses totais novas, por meio de planigrafias laterais da ATM (2000). O critério de seleção dos pacientes foi aleatório e, mediante a amostra escolhida, foi preenchido um questionário clínico-anamnésico, seguido de tomadas radiográficas com o par de dentaduras antigas e novas em 12 pacientes. verificou-se que a posição condilar em desdentados totais na primeira tomada radiográfica situou-se mais para anterior em $100 \%$ dos casos. Já o deslocamento condilar após instalação das novas próteses resultou em uma tendência de deslocamento para posterior em $75 \%$ dos indivíduos. Não houve qualquer correlação estatisticamente significativa entre variações das posições condilares e dimensões verticais de oclusão. O autor ainda concluiu que a tendência de localização para posterior possivelmente não irá causar danos aos pacientes, tendo em vista se tratarem de indivíduos assintomáticos.

Em 2002, MAJOR et al. ${ }^{66}$, verificaram as associações existentes entre as características ósseas da ATM e desarranjo interno em adolescentes. Imagens de ressonância magnética foram utilizadas para 
determinação da posição condilar e tomografias foram realizadas para análise do padrão ósseo. Os espaços articulares também foram avaliados nas imagens tomográficas corrigidas e as médias dos espaços articulares obtidas para os pacientes do gênero masculino foram de 2,2; 3,32; e 2,74 $\mathrm{mm}$ para os espaços anterior, superior e posterior, respectivamente. No sexo feminino, as médias desses espaços foram de 2,24; 2,87 e 2,56mm. A análise de regressão linear identificou associações entre deslocamento de disco e redução do espaço articular superior, aumento do espaço articular posterior e anterior, e ainda diminuição da convexidade da eminência articular. Nesse estudo, os autores concluíram que o desarranjo interno está associado à adaptação óssea funcional da articulação temporomandibular.

As possíveis alterações da ATM após o tratamento ortodôntico foram verificadas por CARLTON; NANDA ${ }^{10}$ (2002). Para isso, os autores analisaram tomografias das ATMs antes e após a conclusão do tratamento ortodôntico em 106 pacientes ortodônticos, sendo 58 tratados de má oclusão de Classe I e 48 de Classe II, divisão 1. Essa amostra também foi dividida quanto ao gênero, sendo 42 do masculino e 64 do feminino. Os côndilos foram avaliados quanto à concentricidade, baseado na fórmula de PULLINGER; HOLLENDER ${ }^{94}$. Com o tratamento ortodôntico os côndilos se apresentaram mais concêntricos em relação à fossa mandibular. Não se demonstrou associação entre as alterações do relacionamento côndilo-fossa com as variáveis de idade, gênero, características dentárias e esqueléticas, sinais e sintomas de DTM e mecânica ortodôntica.

Em 2003, SANTOS et al. ${ }^{112}$, apresentaram um método para mensuração da posição condilar utilizando a técnica da transcraniana proposta por UpDegrave. A radiografia utilizada para a apresentação do método foi obtida de um paciente com má oclusão de Classe II de Angle, sendo que o mesmo se encontrava em MIH durante a tomada radiográfica. O paciente manteve-se sentado, com a face apoiada no suporte, com inclinação de $15^{\circ}$ em relação ao solo, com o feixe de raio $x$ incidindo $2 \mathrm{~cm}$ atrás e $5 \mathrm{~cm}$ acima do conduto auditivo externo do lado oposto que seria 
radiografado. Os espaços articular superior, anterior e posterior foram mensurados no traçado realizado sobre a radiografia transcraniana. Essas medidas foram efetuadas utilizando-se três linhas de referência, a primeira passando pelo centro médio do colo do côndilo até a fossa mandibular, e as outras duas em $45^{\circ}$ em relação à primeira. Utilizando-se os valores padrão para os espaços articulares estipulados por Christiansen, de 1,5 a $2 \mathrm{~mm}$ para o espaço articular anterior e 2 a 3,1 mm para o posterior, para que o côndilo fosse centralizado, os autores relataram que o côndilo do paciente exemplificado se encontrava centralizado. Em relação à técnica empregada no estudo, os mesmos concluíram que a radiografia transcraniana oferece bons resultados para avaliação dos espaços articulares, presença de osteófitos e doença degenerativa da ATM. Enfatizaram, ainda, algumas vantagens dessa técnica como: baixo custo, rapidez, facilidade, possibilidade de padronização das tomadas e eficácia na mensuração da concentricidade condilar.

Nesse mesmo ano, PEREIRA ${ }^{88}$, objetivando comparar as estruturas da ATM em pacientes portadores e não portadores de DTM, realizou ultra-sonografia estática e tomografia linear em uma amostra de 40 adolescentes, com idades entre 12 e 18 anos de idade. Esses jovens foram divididos em dois grupos: o grupo I composto por 20 jovens (10 de cada gênero) considerados livres de sinais e sintomas de DTM baseado no índice craniomandibular; o grupo II composto pelo mesmo número de participantes, também divididos igualmente em relação ao gênero, porém apresentando DTM de acordo com o índice empregado. O autor concluiu que 0 posicionamento condilar mostrou-se mais posteriorizado no grupo com DTM de maneira significativa quando comparado ao grupo I, sendo essa posição posterior mais freqüente nas jovens. Apesar desses resultados, o autor ressalta que com esse estudo não se deve inferir uma relação causa-efeito entre a posteriorização condilar e a presença de DTM. 
3- Proposição 


\section{3-PROPOSIÇÃO}

Esse trabalho propõe-se a:

3.1- Determinar a prevalência de sinais e sintomas de DTM em pacientes submetidos à terapia ortopédica protrusiva;

3.2- Determinar a participação de fatores oclusais na etiologia das DTMs;

3.3- Verificar as alterações na posição condilar causada pela terapia ortopédica protrusiva;

3.4- Comparar a concentricidade condilar em grupos antes, durante e após o tratamento;

3.5- Determinar a relação entre concentricidade condilar e sinais e sintomas de DTM. 
4- Materiais e Métodos 


\section{4- MATERIAL E MÉTODOS}

\section{1 - AMOSTRA}

A amostra foi composta por 60 pacientes divididos da seguinte forma:

a) Grupo I: Composto por 20 pacientes com má oclusão de Classe II, indicados para tratamento com o aparelho Bionator, porém sem ainda receber nenhum tipo de terapia.

b) Grupo II: Composto por 20 pacientes em tratamento com aparelho Bionator.

c) Grupo III: constituído por 20 pacientes previamente submetidos a tratamento ortodôntico-ortopédico de má oclusão de Classe II com o Bionator.

Os pacientes da amostra foram selecionados aleatoriamente do curso de Ortodontia Preventiva e Interceptora da Profis, do Hospital de anomalias craniofaciais, da Universidade de São Paulo.

Foram excluídos pacientes com história de traumatismo faciais e portadores de doenças sistêmicas, como osteoartrites e fibromialgia, e também indivíduos com grandes perdas dentárias ou submetidos previamente a terapias oclusais e/ou para DTM.

\section{2 - APLICAÇÃO DO QUESTIONÁRIO}

Solicitou-se aos pacientes o preenchimento de fichas contendo informações pessoais e questões sobre sintomas relativos às DTMS.

1) Dados pessoais: questões relacionadas a nome, idade, gênero, endereço e telefone.

2) Questionário anamnésico

Este questionário foi desenvolvido baseado em fichas préexistentes $^{18,29,38,39}$ e aplicado aos pacientes, sem interferência do examinador, de 
modo que não se criasse uma expectativa com possibilidade de desviar os resultados do exame clínico a ser realizado. Os pacientes responderam a 10 perguntas relativas a sintomas, o que permitiu a obtenção de uma classificação do indivíduo em relação à presença e severidade de disfunção. Esse questionário foi modificado a partir de trabalhos prévios que demonstraram a eficiência da obtenção de um diagnóstico pela anamnese ${ }^{18}$ (Figura 4.1).

1. Você sente dificuldade em abrir a boca?

2. Você sente dificuldade em movimentar sua mandíbula para os lados?

3. Você sente desconforto ou dor muscular quando mastiga?

4. Você sente dores de cabeça, com freqüência ?

5. Você sente dores no pescoço e/ou ombros ?

6. Você sente dores de ouvido ou próximo a ele ?

7. Você percebe algum ruído na ATM ?

8. Você considera sua mordida "normal" ?

9. Você usa apenas um lado de sua boca para mastigar?

10.Você sente dores na face, ao acordar?

FIGURA 4.1- Questionário anamnésico

Ainda questões sobre tensão emocional e a presença de hábitos parafuncionais deletérios foram respondidas pelos indivíduos de toda a amostra. Apertamento dos dentes, bruxismo, onicofagia, entre outros, constituíam os hábitos presentes na ficha de anamnese.

Para as questões do questionário anamnésico foi oferecida a possibilidade de três respostas: "sim", "não" ou "às vezes". Para cada resposta indicando a presença do sintoma foi atribuído valor "2", à ausência de sintomas valor "0" e a resposta "às vezes" valor "1". 
Nas questões 6 e 7, a presença de sintomas bilaterais recebeu valor "3", a ser somado no índice de DTM.

Também para a questão 4, um escore "3" foi atribuído quando relatado que a dor era freqüente e intensa. A somatória dos valores obtidos permitiu a classificação da amostra em relação à DTM, sendo referida, a partir de agora, como Índice de DTM.

Valores de 0 a 3: $\quad$ não portador de DTM

Valores de 4 a 8: $\quad$ portador de DTM leve

Valores de 9 a 14: $\quad$ portador de DTM moderada

Valores de 15 a 23: $\quad$ portador de DTM severa

\subsection{HISTÓRIA MÉDICA}

Os pacientes relataram a ocorrência de problemas de saúde relacionados aos sistemas cardiovascular, digestivo, musculoesqueletal, endócrino, respiratório e neurológico.

\subsection{EXAME FÍsICO}

Os materiais utilizados para o exame físico foram :
a) papel celofane;
b) fita detectora de contatos (Accu-Film) ${ }^{*}$;
c) pinça de Miller;
d) espelho clínico;

\footnotetext{
* Accu-Film II (Red-Black- Parkell- N.Y.- U.S.A.)
} 
O exame físico foi realizado por dois examinadores treinados, previamente calibrados. A calibração constou de treinamento de posição e pressão de palpação muscular e da ATM, assim como de identificação dos fatores oclusais. Os examinadores avaliaram os pacientes sentados, em posição relaxada. Esse exame constou de três fases: avaliação da ATM, exame muscular e avaliação dentária e oclusal.

\subsubsection{Avaliação da ATM}

Os movimentos mandibulares foram os primeiros itens analisados. Observou-se o grau de abertura máxima ativa (incluindo o trespasse), lateralidade direita e esquerda e a protrusão.

A presença de ruídos articulares a partir da inspeção das ATM direita e esquerda foi também avaliada. Para se considerar o estalido como presente era necessário que este se repetisse por 3 vezes $^{27}$. Essa avaliação foi efetuada posicionando-se levemente os dedos indicadores na região correspondente ao polo lateral do côndilo, à frente do meato acústico externo, enquanto o paciente realizava movimentos de abertura e fechamento mandibular.

A avaliação da presença de sintomatologia dolorosa na ATM foi realizada primeiramente orientando-se o paciente quanto à diferença entre pressão e desconforto, para maior confiabilidade nas respostas. Esse exame foi executado com a palpação digital bilateral, com os dedos indicadores colocados 10 a $20 \mathrm{~mm}$ à frente do conduto auditivo externo. O aspecto lateral da ATM foi palpado com o paciente de boca fechada e o aspecto posterior foi palpado com o paciente de boca aberta. Pressionaram-se essas regiões de maneira delicada e contínua, com uma força aproximada de 900 gramas, de acordo com AUSTIN; PERTES ${ }^{5}$. 


\subsubsection{Exame muscular}

Para o exame da palpação muscular, as mesmas orientações diferenciando dor e desconforto foram dadas aos pacientes. A palpação foi efetuada com pressão digital bilateral, exercendo-se uma pressão constante de aproximadamente 1500 gramas, de acordo com CONTI et al. ${ }^{18}$. A presença de dor era constatada diante do reflexo palpebral e/ou questionamento ao paciente.

Os seguintes músculos foram palpados: temporal anterior, médio e posterior; origem, inserção e corpo do masseter superficial; masseter profundo; digástrico posterior; esternocleidomastoideo e trapézio superior.

\subsubsection{Avaliação dentária e oclusal}

Toda a cavidade bucal foi inspecionada, procurando-se verificar a ausência de dentes, facetas de desgaste, trespasse vertical e horizontal, relações maxilomandibulares, presença e tipo de guias lateral e anterior, interferências no lado de não-trabalho, número de contatos dentários em $\mathrm{MIH}$. A mensuração dos trespasses horizontal e vertical foi realizada com o auxílio de uma régua milimetrada.

Para se averiguar as diferenças das posições maxilomandibulares obteve-se a posição de RC com a técnica de manipulação unilateral do paciente ${ }^{119}$, e comparou-se com a posição de MIH, medindo-se a discrepância sagital entre as duas posições.

Solicitou-se aos pacientes a realização de movimentos laterais da mandíbula, para a avaliação da presença e do tipo de guia lateral, utilizando-se uma tira de papel celofane para verificar a presença de interferências no lado de nãotrabalho. A presença de guia anterior foi conferida pedindo-se aos pacientes para protruir a mandíbula até a posição de topo. O número de contatos em MIH foi obtido interpondo uma folha de Accu-Film entre os dentes, enquanto o paciente abria e fechava a boca.

Os tipos de má oclusão foram considerados classificando-se a relação sagital do paciente em relação de Classe I, Classe II de até meia cúspide e Classe II 
maior que meia cúspide. Ainda em relação aos tipos de má oclusão, observou-se a presença de mordida aberta e mordida cruzada posterior, discriminando-se esta última em unilateral e bilateral.

Avaliou-se, ainda, nos pacientes do grupo III, se os mesmos foram tratados ou não com ortodontia corretiva para finalizar e intercuspidar melhor os dentes após o tratamento com o Bionator.

\subsection{EXAME RADIOGRÁFICO}

Foram realizadas radiografias transcranianas padronizadas das ATMs direita e esquerda nas posições de boca fechada e abertura máxima. Os exames radiográficos foram realizados no Serviço de Radiologia do Departamento de Estomatologia da Faculdade de Odontologia de Bauru, da Universidade de São Paulo.

As exposições radiográficas obedeceram a um regime de exposição de $75 \mathrm{KV}, 10 \mathrm{~mA}$, fixo, com tempo de exposição de 11 segundos. A revelação do filme foi realizada por meio de processamento automático.

O objetivo principal dessa análise radiográfica foi avaliar a posição condilar em relação à fossa mandibular. Eventuais processos degenerativos ou diminuição do espaço articular também foram registrados.

As imagens radiográficas foram digitalizadas, aplicando-se um fator de correção para que a imagem representasse a condição real da radiografia. Nessa etapa, 15 pacientes foram excluídos da amostra, por apresentarem radiografias de difícil identificação, fato esse julgado por 3 avaliadores independentes e previamente calibrados. As 60 radiografias (120 ATMs) que fizeram parte do trabalho foram avaliadas de maneira "mascarada" pelos 3 avaliadores da maneira proposta por PULLINGER; HOLLENDER ${ }^{94}$. Foram mensuradas, com auxílio do programa Adobe Photoshop*, os menores espaços articulares superior $(S)$, posterior $(P)$ e anterior $(A)$. (Figura 4.2) 


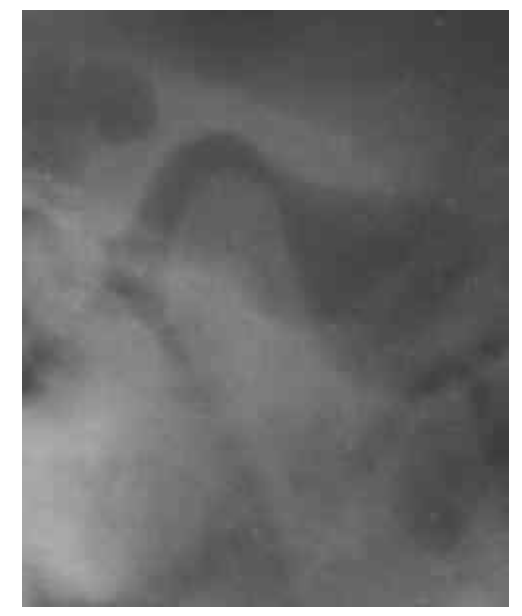

Figura 4.2: Imagem transcraniana digitalizada

Foi realizado, então, cálculo de médias aritméticas dos valores julgados pelos três examinadores, aplicando-se a seguinte fórmula que determinou o percentual de concentricidade condilar:

$$
\frac{P-A}{P+A} \quad x \quad 100 \%
$$

Valores negativos indicam um posicionamento condilar posterior, enquanto valores percentuais positivos indicam côndilos anteriorizados em relação à fossa mandibular. Valor "zero" indica a concentricidade absoluta do côndilo.

\subsection{ANÁLISE ESTATÍSTICA}

O teste de análise de variância (ANOVA) para dados não paramétricos (Kruskal-Wallis) foi utilizado para avaliar as diferenças intergrupos em relação à presença e/ou severidade de DTM.

O teste de ANOVA a um critério para comparações entre os grupos em relação à concentricidade condilar (post-hoc: Tukey) foi empregado, assim como o 
teste de Correlação de Spearman para relação entre DTM e concentricidade condilar.

A associação entre a presença de DTM e as diversas condições estudadas foi testada empregando-se o teste do qui-quadrado, assumindo um nível de probabilidade de $95 \%$. Tais procedimentos foram executados com o auxílio dos softwares Sigma Stat ${ }^{*}$ e Systat*.

\footnotetext{
* Sigmastat for windows version 2.0 Jandel Corporation, Softek Inc., USA

${ }^{* *}$ Systat 5.02 for windows. Systat, Inc., Evanston, Ir, USA.
} 
5- Resultados 


\section{5- $\quad$ RESULTADOS}

\subsection{CARACTERÍSTICAS DESCRITIVAS}

$\mathrm{Na}$ amostra total, composta por 60 indivíduos, a média de idade foi de 12,58 $\pm 3,72$ anos de idade, sendo a idade mínima de 7 e a máxima de 23 anos.

Em relação ao gênero, 26 homens $(43,4 \%)$ e 34 mulheres (56,6\%) constituíram a amostra, igualmente distribuídos entre os grupos estudados.

Inicialmente, foi realizada a análise descritiva da amostra referente aos seguintes parâmetros: grau de abertura bucal, extensão dos movimentos de lateralidade direita, esquerda e protrusão, quantidade dos trespasses vertical e horizontal e número de contatos em MIH (Tabelas $5.1 \mathrm{e}$ $5.2)$.

Tabela 5.1: Valores (em $\mathrm{mm}$ ) das médias e desvios padrão acompanhados dos valores mínimo e máximo da abertura, lateralidades direita e esquerda e protrusão da amostra total

\begin{tabular}{l|c|c|c|c}
\cline { 2 - 5 } & $\begin{array}{c}\text { Abertura } \\
(\mathbf{m m})\end{array}$ & $\begin{array}{c}\text { Lateralidade } \\
\text { direita }(\mathbf{m m})\end{array}$ & $\begin{array}{c}\text { Lateralidade } \\
\text { esquerda } \mathbf{( m m})\end{array}$ & $\begin{array}{c}\text { Protrusão } \\
\mathbf{( m m})\end{array}$ \\
\hline Média $\pm \mathbf{d p}$ & $48,6 \pm 5,31$ & $8,8 \pm 2,13$ & $8,8 \pm 2,13$ & $7,73 \pm 1,79$ \\
Mínimo & 36 & 4 & 2 & 3 \\
Máximo & 59 & 14 & 13 & 11 \\
\hline
\end{tabular}


Tabela 5.2: Valores (em $\mathrm{mm}$ ) das médias e desvios padrão acompanhados dos valores mínimos e máximos dos trespasses horizontal e vertical e do número de contatos em $\mathrm{MIH}$ da amostra total.

\begin{tabular}{l|c|c|c}
\cline { 2 - 4 } & $\begin{array}{c}\text { Trespasse } \\
\text { Horizontal }(\mathbf{m m})\end{array}$ & $\begin{array}{c}\text { Trespasse } \\
\text { Vertical }(\mathbf{m m})\end{array}$ & $\begin{array}{c}\text { Contatos em MIH } \\
\left(\mathbf{n}^{\mathbf{0}}\right)\end{array}$ \\
\hline Média $\pm \mathrm{dp}$ & $3,77 \pm 2,32$ & $2,77 \pm 2.16$ & $7,53 \pm 4.38$ \\
Mínimo & 0 & -7 & 2 \\
Máximo & 10 & 8 & 22 \\
\hline
\end{tabular}

\section{2- DISFUNÇÃO TEMPOROMANDIBULAR}

Verificou-se a prevalência de DTM nos três grupos estudados, de acordo com o questionário anamnésico descrito anteriormente (Tabela 5.3 e Figura 5.1). De acordo com o teste de Kruskal-Wallis, não houve diferença entre a presença de um dos subtipos de DTM nos diferentes grupos estudados (Kruskal Wallis $=2,991, p=0,224$, assumindo uma distribuição de qui-quadrado com 2 graus de liberdade).

Tabela 5.3: Prevalência de DTM nos diferentes grupos (valores absolutos e percentuais)

\begin{tabular}{l|c|c|c|c}
\hline \multicolumn{1}{c|}{ Grupo } & $\begin{array}{c}\text { I - Pré- } \\
\text { tratamento }\end{array}$ & $\begin{array}{c}\text { II - Em } \\
\text { tratamento }\end{array}$ & $\begin{array}{c}\text { III - Pós- } \\
\text { tratamento }\end{array}$ & Total \\
\hline Ausente & $10(50 \%)$ & $15(75 \%)$ & $15(75 \%)$ & $40(66,67 \%)$ \\
Leve & $10(50 \%)$ & $5(25 \%)$ & $3(15 \%)$ & $18(30 \%)$ \\
Moderada & $0(0 \%)$ & $0(0 \%)$ & $2(10 \%)$ & $2(3,33 \%)$ \\
Total & $20(100 \%)$ & $20(100 \%)$ & $20(100 \%)$ & $60(100 \%)$ \\
\hline
\end{tabular}




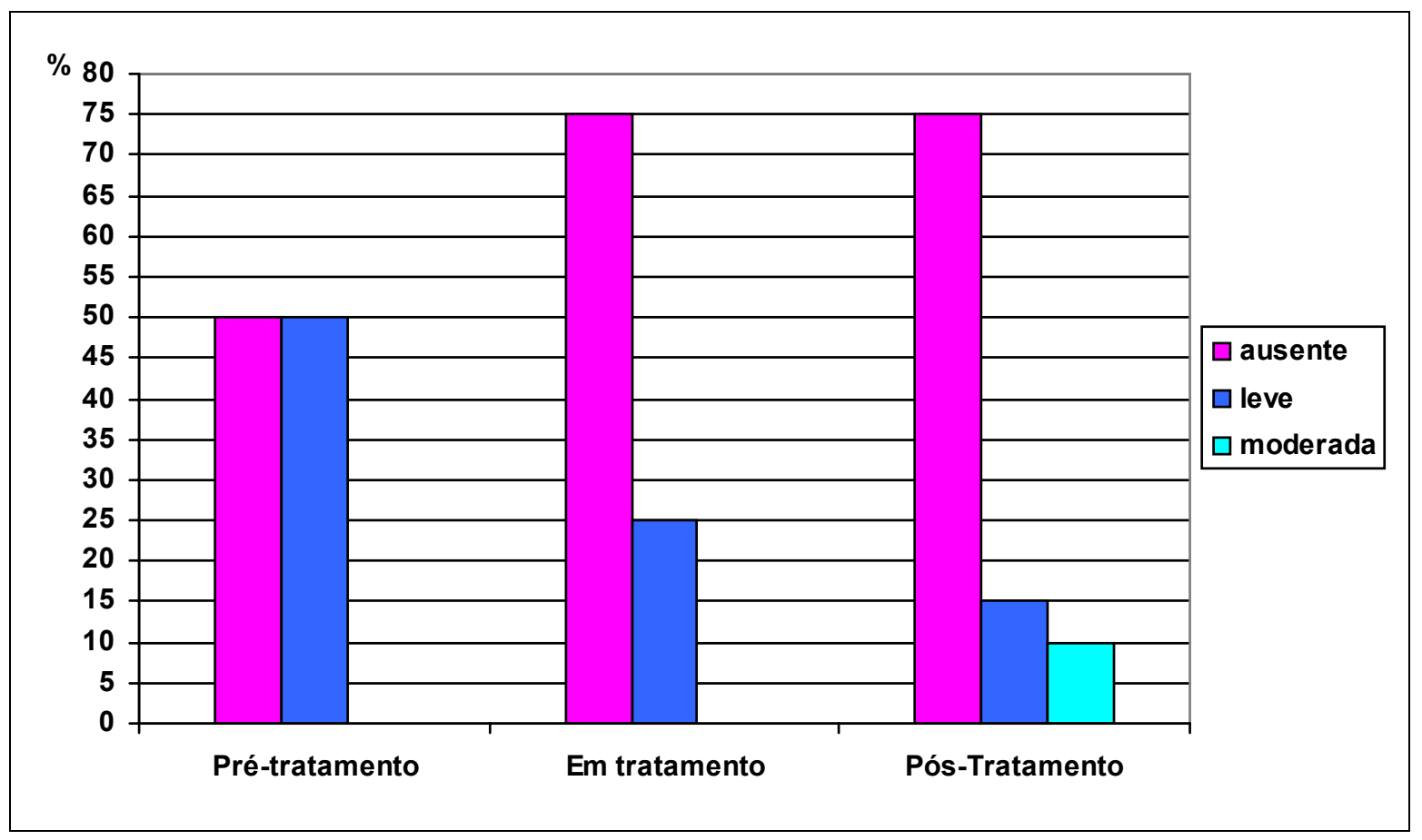

Figura 5.1: Valores percentuais da presença e severidade de DTM em cada grupo

Os resultados das questões individuais que compuseram o índice anamnésico estão divididos por grupos e listados na Tabela 5.4. 
Tabela 5.4: Valores absolutos e percentuais das respostas ao questionário de DTM nos diferentes grupos

\begin{tabular}{|c|c|c|c|c|c|}
\hline \multicolumn{2}{|c|}{ Questão } & $\begin{array}{c}\text { I - Pré- } \\
\text { tratamento }\end{array}$ & $\begin{array}{c}\text { II - Em } \\
\text { tratamento }\end{array}$ & $\begin{array}{l}\text { III - Pós- } \\
\text { tratamento }\end{array}$ & Total \\
\hline \multirow[t]{2}{*}{1} & Às vezes & $1(1,67 \%)$ & $0(0 \%)$ & $1(1,67 \%)$ & $2(3,33 \%)$ \\
\hline & Não & $19(31,67 \%)$ & $20(33,33 \%)$ & $19(31,67 \%)$ & $58(96,67 \%)$ \\
\hline \multirow[t]{3}{*}{2} & Sim & $0(0 \%)$ & $1(1,67 \%)$ & $0(0 \%)$ & $1(1,67 \%)$ \\
\hline & Não & $19(31,67 \%)$ & $19(31,67 \%)$ & $19(31,67 \%)$ & 57 (95\%) \\
\hline & Às vezes & $1(1,67 \%)$ & $0(0 \%)$ & $1(1,67 \%)$ & $2(3,33 \%)$ \\
\hline \multirow[t]{2}{*}{3} & Às vezes & $2(3,33 \%)$ & $1(1,67 \%)$ & $3(5 \%)$ & $6(10 \%)$ \\
\hline & Não & $18(30 \%)$ & $19(31,67 \%)$ & $17(28,33 \%)$ & $54(90 \%)$ \\
\hline \multirow[t]{3}{*}{4} & Sim & $5(8,33 \%)$ & $1(1,67 \%)$ & $2(3,33 \%)$ & $8(13,33 \%)$ \\
\hline & Não & $10(16,67 \%)$ & $15(25 \%)$ & $16(26,67 \%)$ & $41(68,33 \%)$ \\
\hline & Às vez & $5(8,33 \%)$ & $4(6,67 \%)$ & $2(3,33 \%)$ & $11(18,33 \%)$ \\
\hline \multirow[t]{3}{*}{5} & Sim & $1(1$, & $1(1,67 \%)$ & $2\left(3,33^{\circ}\right.$ & $4(6,67 \%)$ \\
\hline & Não & $17(28,33 \%)$ & $17(28,33 \%)$ & $13(21,67 \%)$ & $47(78,33 \%)$ \\
\hline & Às vezes & $2(3,33 \%)$ & $2(3,33 \%)$ & $5(8,33 \%)$ & $9(15 \%)$ \\
\hline \multirow[t]{3}{*}{6} & Sim & $1(1$, & $0(0 \%)$ & & $4(6,67 \%)$ \\
\hline & Não & $15(25 \%)$ & $17(28,33 \%)$ & $15(25 \%)$ & $47(78,33 \%)$ \\
\hline & Às vezes & $4(6,67 \%)$ & $3(5 \%)$ & $5(8,33 \%)$ & $9(15 \%)$ \\
\hline \multirow[t]{3}{*}{7} & Sim & $0(0 \%)$ & $1(1,67 \%)$ & $4(6,67 \%)$ & $5(8,33 \%)$ \\
\hline & Não & $18(3$ & $18(30 \%)$ & $14(23,33 \%)$ & $50(83,33 \%)$ \\
\hline & Às vez & $2(3,3$ & $1(1,67 \%)$ & $2(3,33 \%)$ & $5(8,33 \%)$ \\
\hline \multirow[t]{3}{*}{8} & Sim & $9(15 \%)$ & $15(25 \%)$ & $15(25 \%)$ & $39(65 \%)$ \\
\hline & Não & $11(18,33 \%)$ & $3(5 \%)$ & $5(8,33 \%)$ & $19(31,67 \%)$ \\
\hline & Às vezes & & $2(3,33 \%)$ & & $2(3,33 \%)$ \\
\hline \multirow[t]{3}{*}{9} & Sim & $4(6,67 \%)$ & $3(5 \%)$ & $4(6,67 \%)$ & $11(18,33 \%)$ \\
\hline & Não & $12(20 \%)$ & $12(20 \%)$ & $14(23,33 \%)$ & $58(96,67 \%)$ \\
\hline & Às vez & $4(6,67 \%)$ & $5(8,33 \%)$ & $2(3,33 \%)$ & $11(18,33 \%)$ \\
\hline \multirow[t]{2}{*}{10} & Às vezes & & $2(3,33 \%)$ & $1(1,67 \%)$ & $3(5 \%)$ \\
\hline & Não & $20(33,33 \%)$ & $18(30 \%)$ & $19(31,67 \%)$ & $57(95 \%)$ \\
\hline
\end{tabular}


A Tabela 5.5 e a Figura 5.2 mostram os valores absolutos e percentuais do número de indivíduos que apresentaram dor à palpação na ATM, em pelo menos um ponto (dentre os aspectos lateral e posterior das ATMs esquerda e direita). O resultado do teste de análise de variância a um critério Kruskal-Wallis para os 60 casos, quando a variável dependente foi a palpação da ATM, foi de 1,405 ( $p=0,495)$, indicando, portanto, ausência de diferença entre os grupos em relação à sensibilidade à palpação da ATM.

Tabela 5.5: Valores absolutos e percentuais do número de indivíduos com e sem dor à palpação da ATM.

\begin{tabular}{c|c|c|c|c}
\cline { 2 - 5 } & $\begin{array}{c}\text { I - Pré- } \\
\text { tratamento }\end{array}$ & $\begin{array}{c}\text { II - Em } \\
\text { tratamento }\end{array}$ & $\begin{array}{c}\text { III - Pós- } \\
\text { tratamento }\end{array}$ & Total \\
\hline $\begin{array}{c}\text { Ausência de } \\
\text { dor }\end{array}$ & $16(80 \%)$ & $13(65 \%)$ & $13(65 \%)$ & $42(70 \%)$ \\
$\begin{array}{c}\text { Presença de } \\
\text { dor }\end{array}$ & $4(20 \%)$ & $7(35 \%)$ & $7(35 \%)$ & $18(30 \%)$ \\
Total & $20(100 \%)$ & $20(100 \%)$ & $20(100 \%)$ & $60(100 \%)$ \\
\hline
\end{tabular}

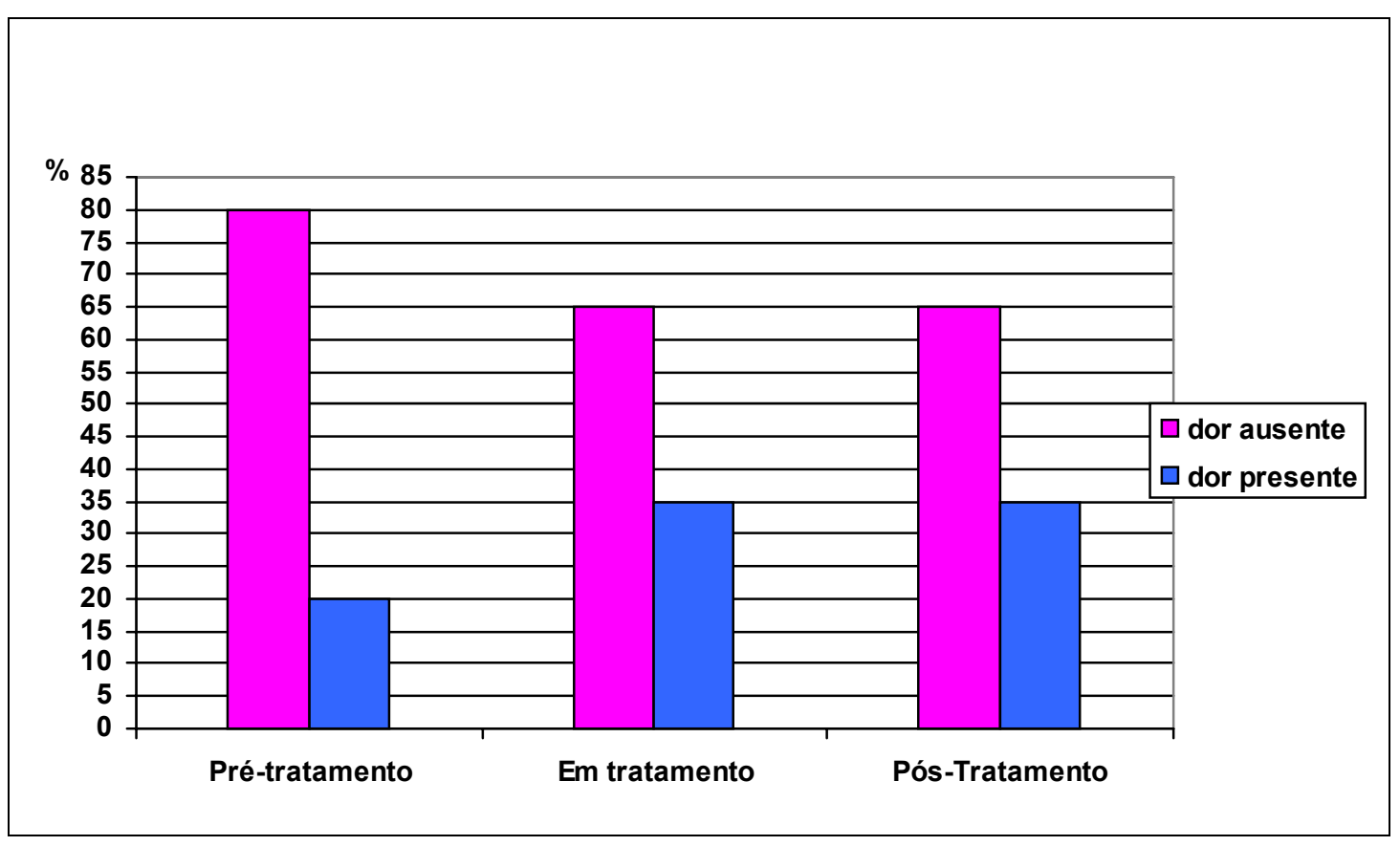

Figura 5.2: Valores percentuais dos indivíduos com e sem dor à palpação da ATM nos diferentes grupos 
A Tabela 5.6 e a Figura 5.3 apresentam os valores absolutos e percentuais do número de indivíduos que apresentaram, pelo menos, 3 pontos de dor à palpação dos músculos mastigatórios ( porções anterior , média e posterior do músculo temporal, porções superficial e profunda do músculo masséter e digástrico posterior). O resultado do teste de análise de variância a um critério Kruskal-Wallis para os 60 casos, quando a variável dependente foi a palpação muscular, foi de 3,275 ( $p=0,194)$, indicando, portanto, ausência de associação entre os grupos e dor muscular à palpação.

Tabela 5.6: Valores absolutos e percentuais do número de indivíduos com e sem dor à palpação dos músculos mastigatórios

\begin{tabular}{c|c|c|c|c}
\cline { 2 - 4 } & $\begin{array}{c}\text { I - Pré- } \\
\text { tratamento }\end{array}$ & $\begin{array}{c}\text { II - Em } \\
\text { tratamento }\end{array}$ & $\begin{array}{c}\text { III - Pós- } \\
\text { tratamento }\end{array}$ & Total \\
\hline $\begin{array}{c}\text { Ausência de } \\
\text { dor }\end{array}$ & $19(95 \%)$ & $19(95 \%)$ & $16(80 \%)$ & $54(90 \%)$ \\
$\begin{array}{c}\text { Presença de } \\
\text { dor }\end{array}$ & $1(5 \%)$ & $1(5 \%)$ & $4(20 \%)$ & $6(10 \%)$ \\
Total & $20(100 \%)$ & $20(100 \%)$ & $20(100 \%)$ & $60(100 \%)$ \\
\hline
\end{tabular}




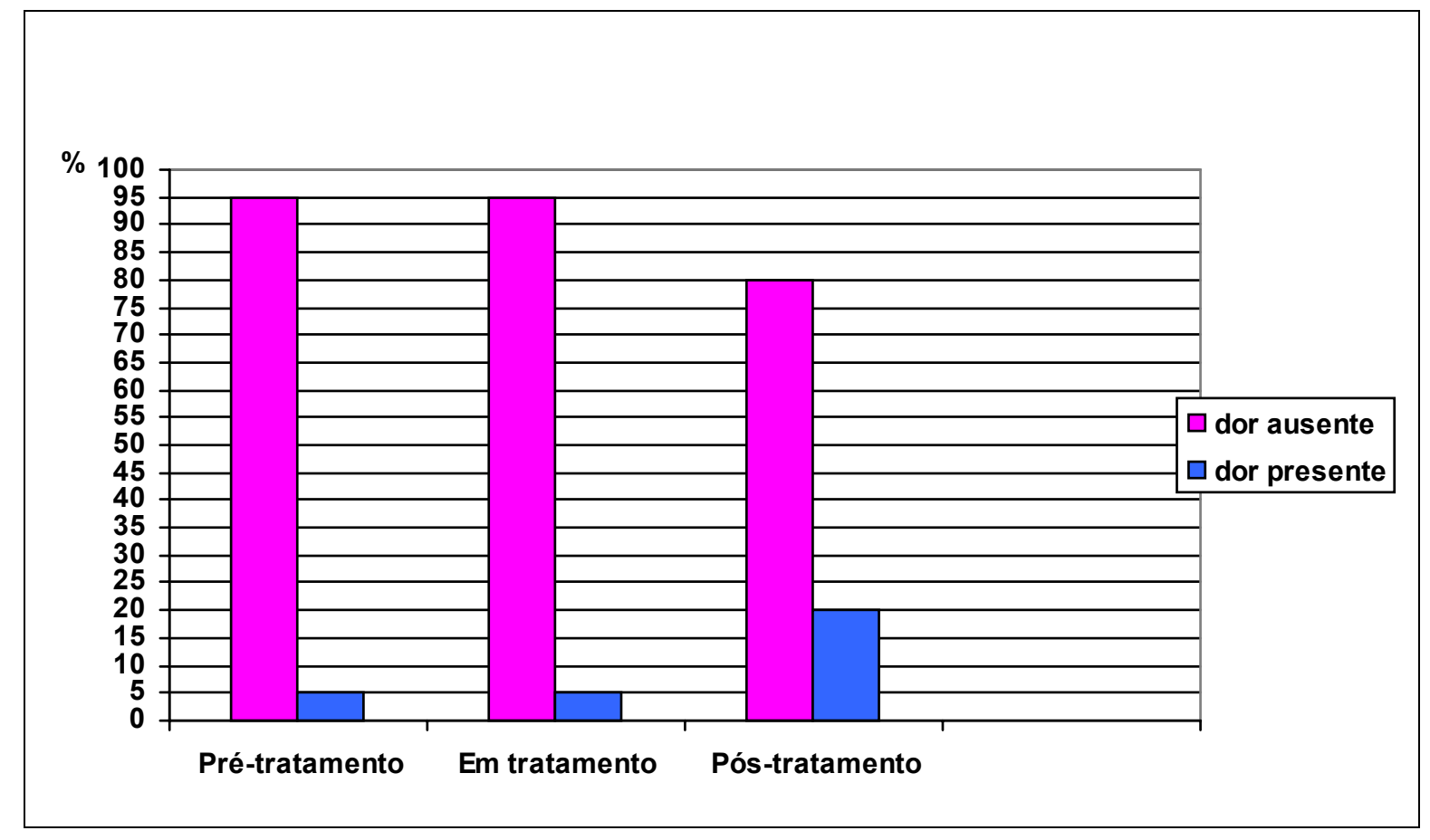

Figura 5.3: Valores percentuais dos indivíduos com e sem dor à palpação dos músculos mastigatórios nos diferentes grupos

A Tabela 5.7 e Figura 5.4 mostram a associação entre a presença de facetas e a presença de DTM, julgada pelo questionário anamnésico. Não houve associação estatisticamente significante (calculada pelo teste qui-quadrado) entre essas variáveis ( $p=0,246)$.

Tabela 5.7: Valores absolutos e percentuais do número de indivíduos com facetas dentárias nos diferentes grupos de DTM

\begin{tabular}{c|c|c|c|c}
\cline { 2 - 5 } & $\begin{array}{c}\text { Ausência } \\
\text { de DTM }\end{array}$ & $\begin{array}{c}\text { DTM } \\
\text { leve }\end{array}$ & $\begin{array}{c}\text { DTM } \\
\text { moderada }\end{array}$ & Total \\
\hline Sem facetas & $24(60 \%)$ & $8(44,44 \%)$ & $2(100 \%)$ & $34(56,67 \%)$ \\
Com facetas & $16(40 \%)$ & $10(55,56 \%)$ & $0(0 \%)$ & $26(43,33 \%)$ \\
TOTAL & $40(100 \%)$ & $18(100 \%)$ & $2(100 \%)$ & $60(100 \%)$ \\
\hline
\end{tabular}




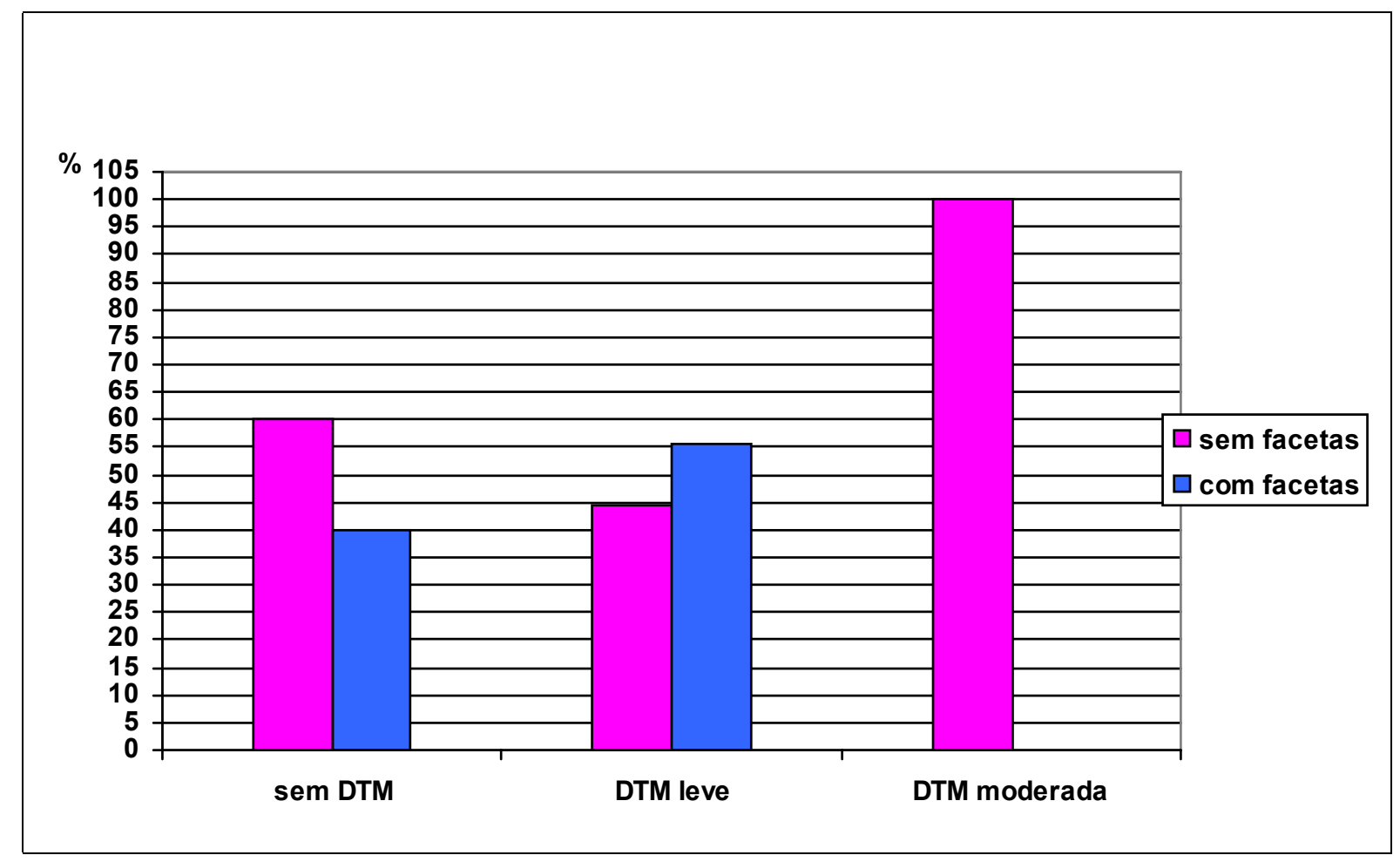

Figura 5.4: Valores percentuais dos indivíduos com e sem facetas dentárias nos diferentes grupos de DTM

Não houve associação entre a ocorrência de mordida aberta e a ocorrência de sinais e/ou sintomas de DTM ( $p=0,499)$. Ver Tabela 5.8 e Figura 5.5 .

Tabela 5.8: Valores absolutos e percentuais do número de indivíduos com e sem mordida aberta anterior nos diferentes grupos de DTM

\begin{tabular}{c|c|c|c|c}
\cline { 2 - 5 } & $\begin{array}{c}\text { Ausência de } \\
\text { DTM }\end{array}$ & $\begin{array}{c}\text { DTM } \\
\text { leve }\end{array}$ & $\begin{array}{c}\text { DTM } \\
\text { moderada }\end{array}$ & Total \\
\hline S/ mordida aberta & $37(92,5 \%)$ & $15(83,33 \%)$ & $2(100 \%)$ & $54(90 \%)$ \\
C/ mordida aberta & $3(7,5 \%)$ & $3(16,67 \%)$ & $0(0 \%)$ & $6(10 \%)$ \\
TOTAL & $40(100 \%)$ & $18(100 \%)$ & $2(100 \%)$ & $60(100 \%)$ \\
\hline
\end{tabular}




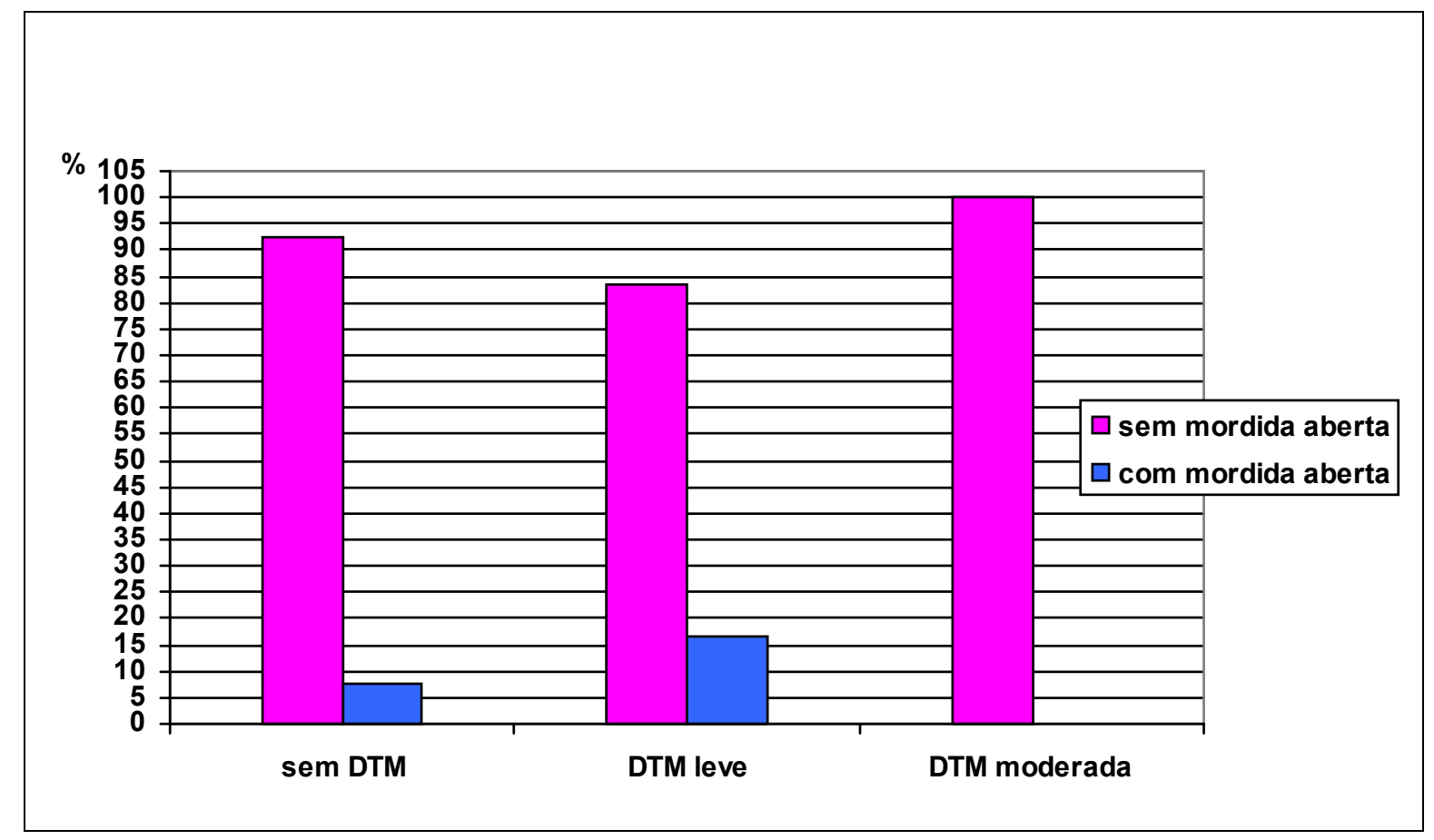

Figura 5.5: Valores percentuais dos indivíduos com e sem mordida aberta anterior nos diferentes grupos de DTM

Quando avaliada a possível relação entre a ocorrência de mordida cruzada unilateral e a presença ou severidade de DTM, não houve uma associação estatisticamente significante $(p=0,359)$. Ver Tabela 5.9 e Figura 5.6.

Tabela 5.9: Valores absolutos e percentuais do número de indivíduos com mordida cruzada unilateral nos diferentes grupos de DTM

\begin{tabular}{c|c|c|c|c}
\cline { 2 - 4 } & $\begin{array}{c}\text { Ausência } \\
\text { de DTM }\end{array}$ & $\begin{array}{c}\text { DTM } \\
\text { leve }\end{array}$ & $\begin{array}{c}\text { DTM } \\
\text { moderada }\end{array}$ & Total \\
\hline $\begin{array}{c}\text { S/ mordida cruzada } \\
\text { unilateral }\end{array}$ & $39(87,5 \%)$ & $16(88,89 \%)$ & $2(100 \%)$ & $57(95 \%)$ \\
$\begin{array}{c}\text { C/ mordida cruzada } \\
\text { unilateral }\end{array}$ & $1(12,5 \%)$ & $2(11,11 \%)$ & $0(0 \%)$ & $3(5 \%)$ \\
TOTAL & $40(100 \%)$ & $18(100 \%)$ & $2(100 \%)$ & $60(100 \%)$ \\
\hline
\end{tabular}




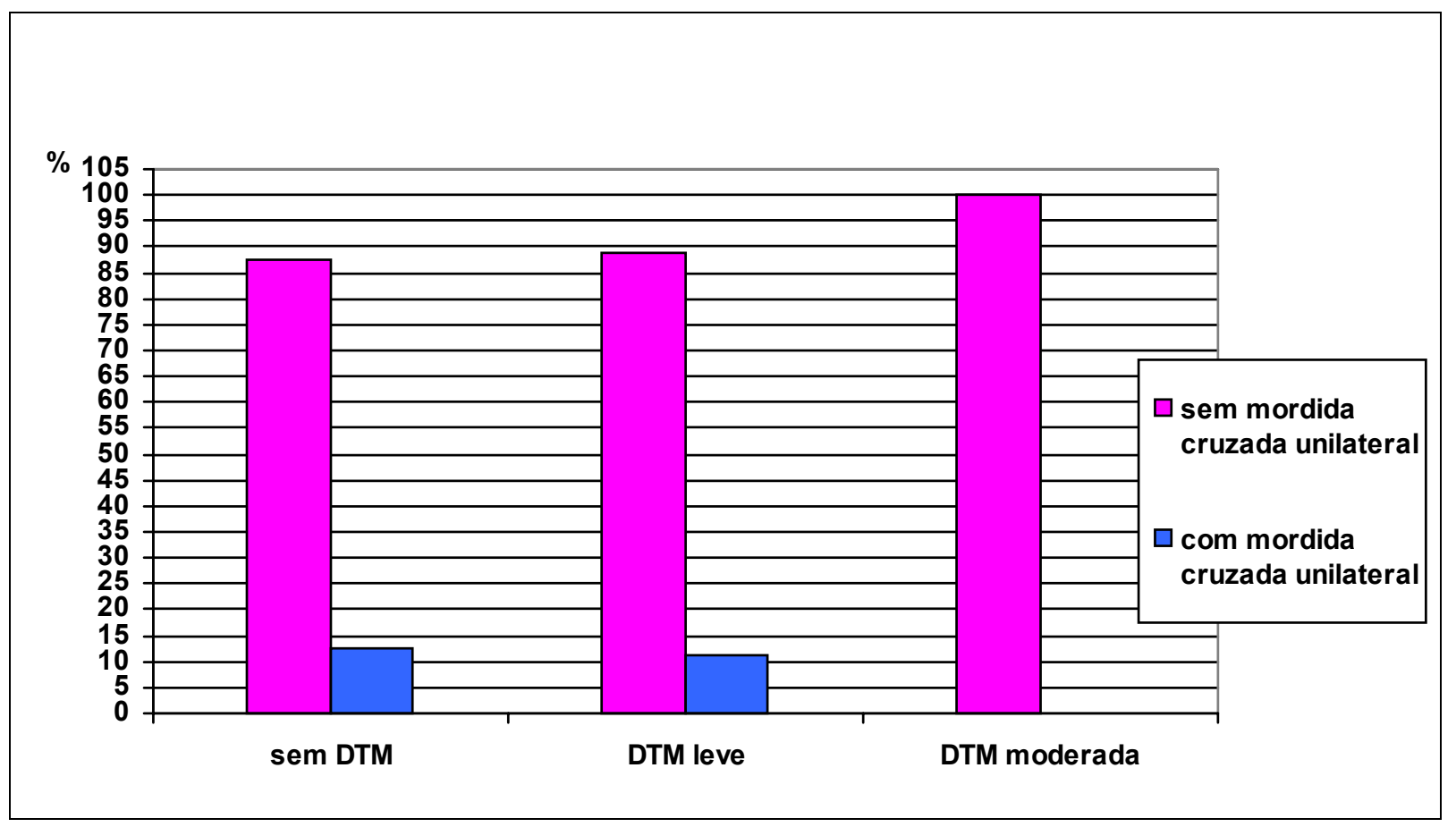

Figura 5.6: Valores percentuais dos indivíduos com e sem mordida cruzada unilateral nos diferentes grupos de DTM.

Não houve também associação entre a severidade da má oclusão e a presença ou severidade de DTM ( $p=0,237)$. Ver Tabela 5.10 e Figura 5.7.

Tabela 5.10: Valores absolutos e percentuais do número de indivíduos com diferentes relações sagitais nos diferentes grupos de DTM.

\begin{tabular}{l|c|c|c|c}
\cline { 2 - 5 } & $\begin{array}{c}\text { Ausência } \\
\text { de DTM }\end{array}$ & $\begin{array}{c}\text { DTM } \\
\text { leve }\end{array}$ & $\begin{array}{c}\text { DTM } \\
\text { moderada }\end{array}$ & Total \\
\hline Classe I & $19(47,5 \%)$ & $3(16,67 \%)$ & $1(50 \%)$ & $23(38,33 \%)$ \\
Até meia Classe II & $18(45 \%)$ & $12(66,67 \%)$ & $1(50 \%)$ & $31(51,67 \%)$ \\
Mais de meia Classe II & $3(7,5 \%)$ & $3(16,67 \%)$ & $0(0 \%)$ & $6(10 \%)$ \\
TOTAL & $40(100 \%)$ & $18(100 \%)$ & $2(100 \%)$ & $60(100 \%)$ \\
\hline
\end{tabular}




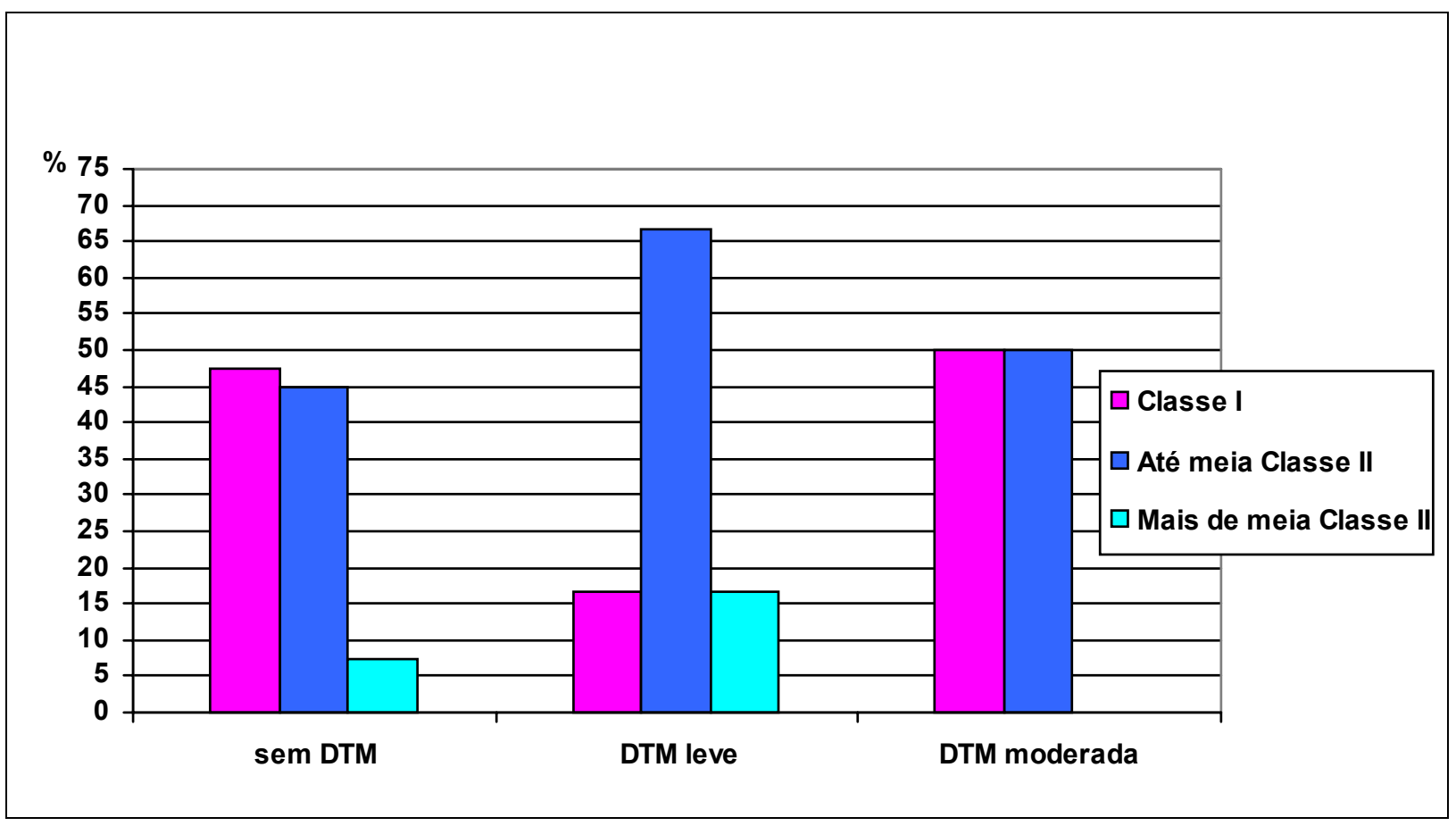

Figura 5.7: Valores percentuais dos indivíduos com diferentes relações sagitais nos diferentes grupos de DTM

Uma não associação estatisticamente significante também foi encontrada quando avaliada a relação entre a discrepância existente entre as posições de RC e MIH e a presença ou severidade de DTM ( $p=0,894)$. Ver Tabela 5.11 e Figura 5.8.

Tabela 5.11: Valores absolutos e percentuais do número de indivíduos com diferentes posicionamentos condilares sagitais nos diferentes grupos de DTM.

\begin{tabular}{l|c|c|c|c}
\cline { 2 - 5 } & $\begin{array}{c}\text { Ausência } \\
\text { de DTM }\end{array}$ & $\begin{array}{c}\text { DTM } \\
\text { leve }\end{array}$ & $\begin{array}{c}\text { DTM } \\
\text { moderada }\end{array}$ & Total \\
\hline Disc RC-MIH de 0 a 2mm & $37(92,5 \%)$ & $17(94,44 \%)$ & $2(100 \%)$ & $56(93,33 \%)$ \\
Disc RC-MIH de 2 a 4mm & $3(7,5 \%)$ & $1(5,56 \%)$ & $0(0 \%)$ & $4(6,67 \%)$ \\
TOTAL & $40(100 \%)$ & $18(100 \%)$ & $2(100 \%)$ & $60(100 \%)$ \\
\hline
\end{tabular}




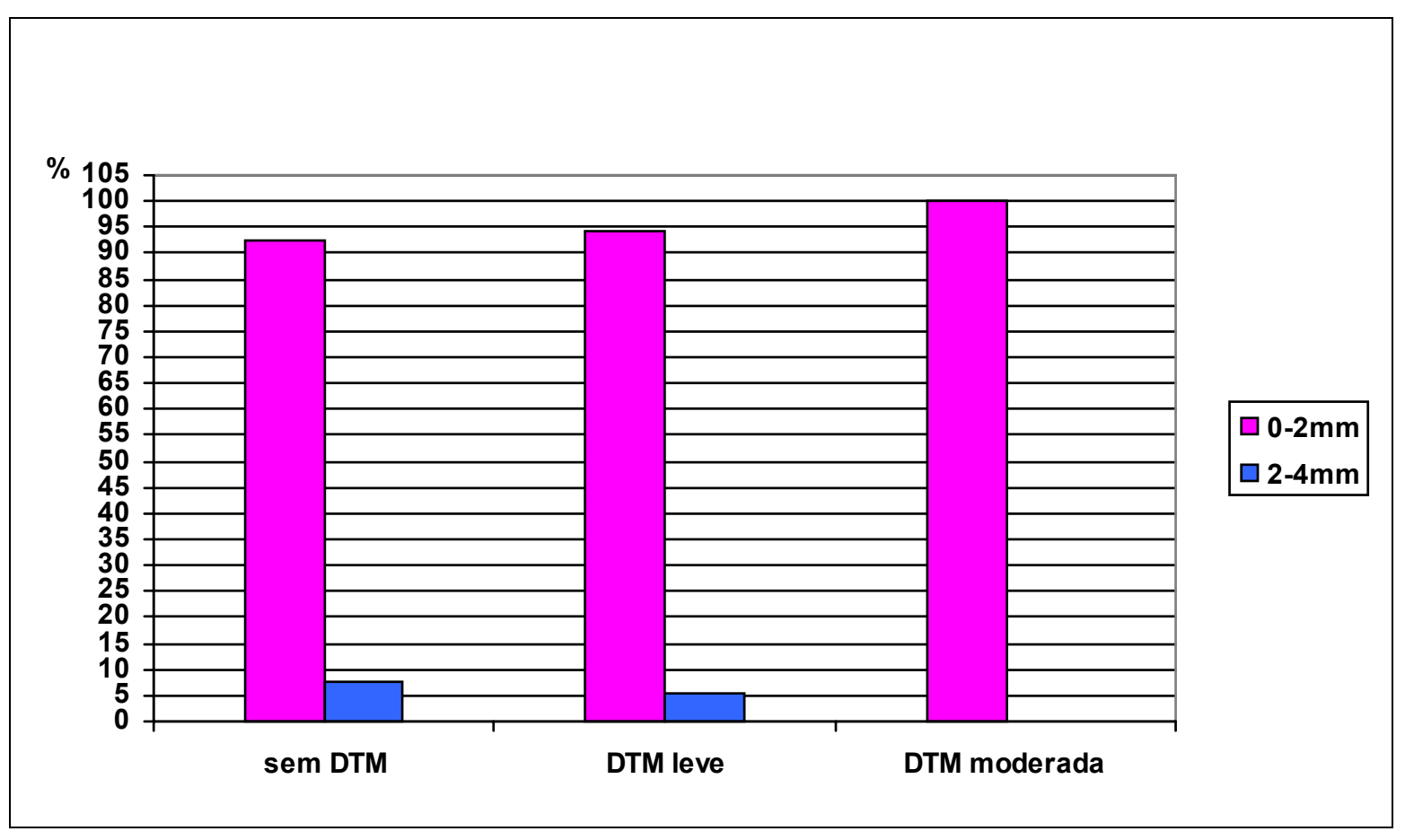

Figura 5.8: Valores percentuais dos indivíduos com diferentes discrepâncias RC-MIH, nos diferentes grupos de DTM

Não houve associação entre a presença de guia de desoclusão direita ou esquerda e a presença ou severidade de DTM $(p=0,173$ e $p=$ 0,606, respectivamente). Tabelas 5.12 e 5.13 e Figuras 5.9 e 5.10 .

Tabela 5.12: Valores absolutos e percentuais do número de indivíduos com diferentes padrões de guia de lateralidade direita, nos diferentes grupos de DTM.

\begin{tabular}{l|c|c|c|c}
\cline { 2 - 5 } & $\begin{array}{c}\text { Ausência } \\
\text { de DTM }\end{array}$ & $\begin{array}{c}\text { DTM } \\
\text { leve }\end{array}$ & $\begin{array}{c}\text { DTM } \\
\text { moderada }\end{array}$ & Total \\
\hline Guia ausente & $16(40 \%)$ & $11(61,11 \%)$ & $0(0 \%)$ & $27(45 \%)$ \\
Guia canino & $14(35 \%)$ & $4(22,22 \%)$ & $2(100 \%)$ & $20(33,33 \%)$ \\
Função em grupo & $10(25 \%)$ & $3(16,67 \%)$ & $0(0 \%)$ & $13(21,67 \%)$ \\
TOTAL & $40(100 \%)$ & $18(100 \%)$ & $2(100 \%)$ & $60(100 \%)$ \\
\hline
\end{tabular}




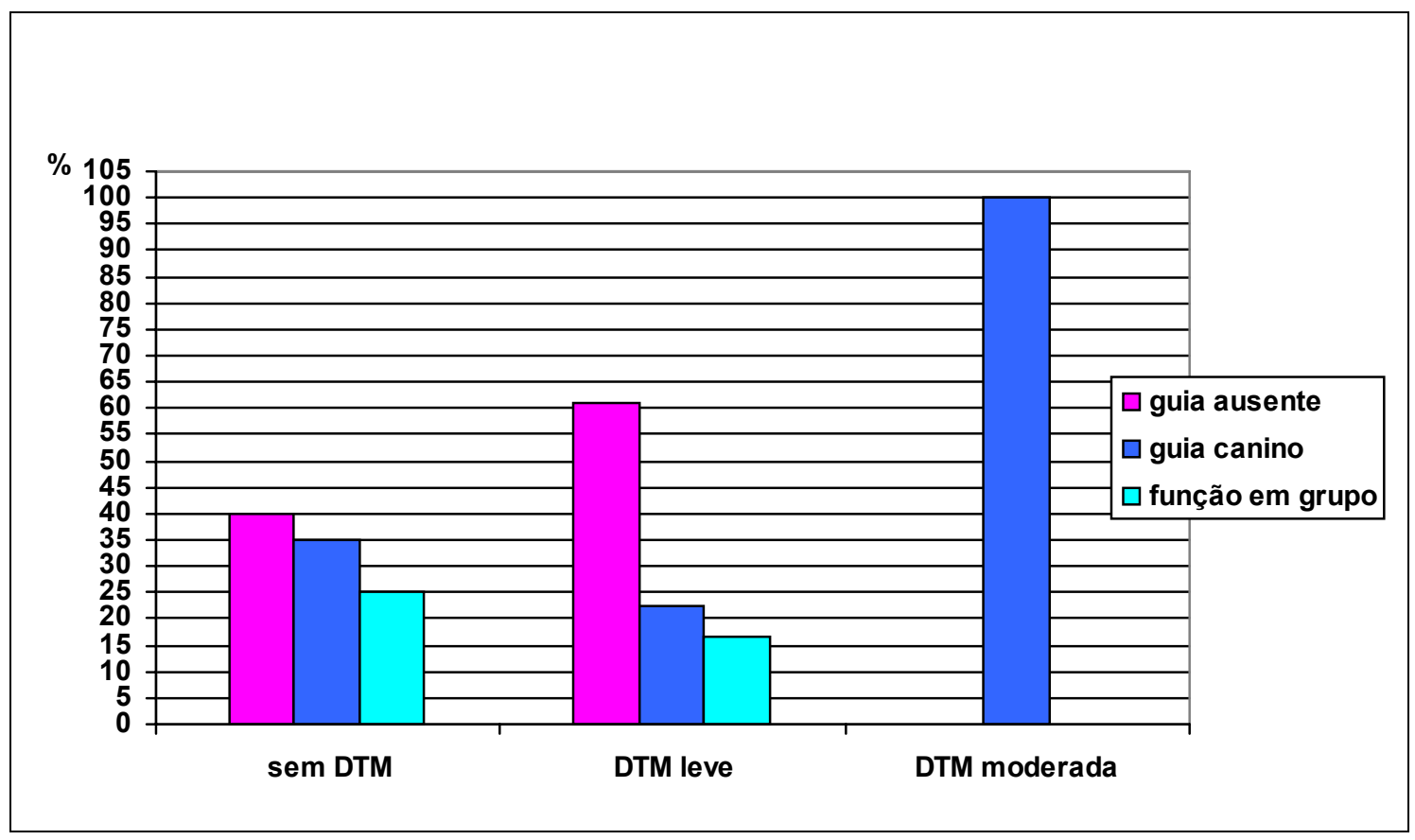

Figura 5.9: Valores percentuais dos indivíduos com diferentes padrões de lateralidade direita nos diferentes grupos de DTM.

Tabela 5.13: Valores absolutos e percentuais do número de indivíduos com diferentes padrões de guia de lateralidade esquerda nos diferentes grupos de DTM.

\begin{tabular}{l|c|c|c|c}
\cline { 2 - 5 } & $\begin{array}{c}\text { Ausência } \\
\text { de DTM }\end{array}$ & $\begin{array}{c}\text { DTM } \\
\text { leve }\end{array}$ & $\begin{array}{c}\text { DTM } \\
\text { moderada }\end{array}$ & Total \\
\hline Guia ausente & $16(40 \%)$ & $7(38,89 \%)$ & $1(50 \%)$ & $24(40 \%)$ \\
Guia canino & $17(42,5 \%)$ & $5(27,78 \%)$ & $1(50 \%)$ & $23(38,33 \%)$ \\
Função em grupo & $7(17,5 \%)$ & $6(33,3 \%)$ & $0(0 \%)$ & $13(21,67 \%)$ \\
TOTAL & $40(100 \%)$ & $18(100 \%)$ & $2(100 \%)$ & $60(100 \%)$ \\
\hline
\end{tabular}




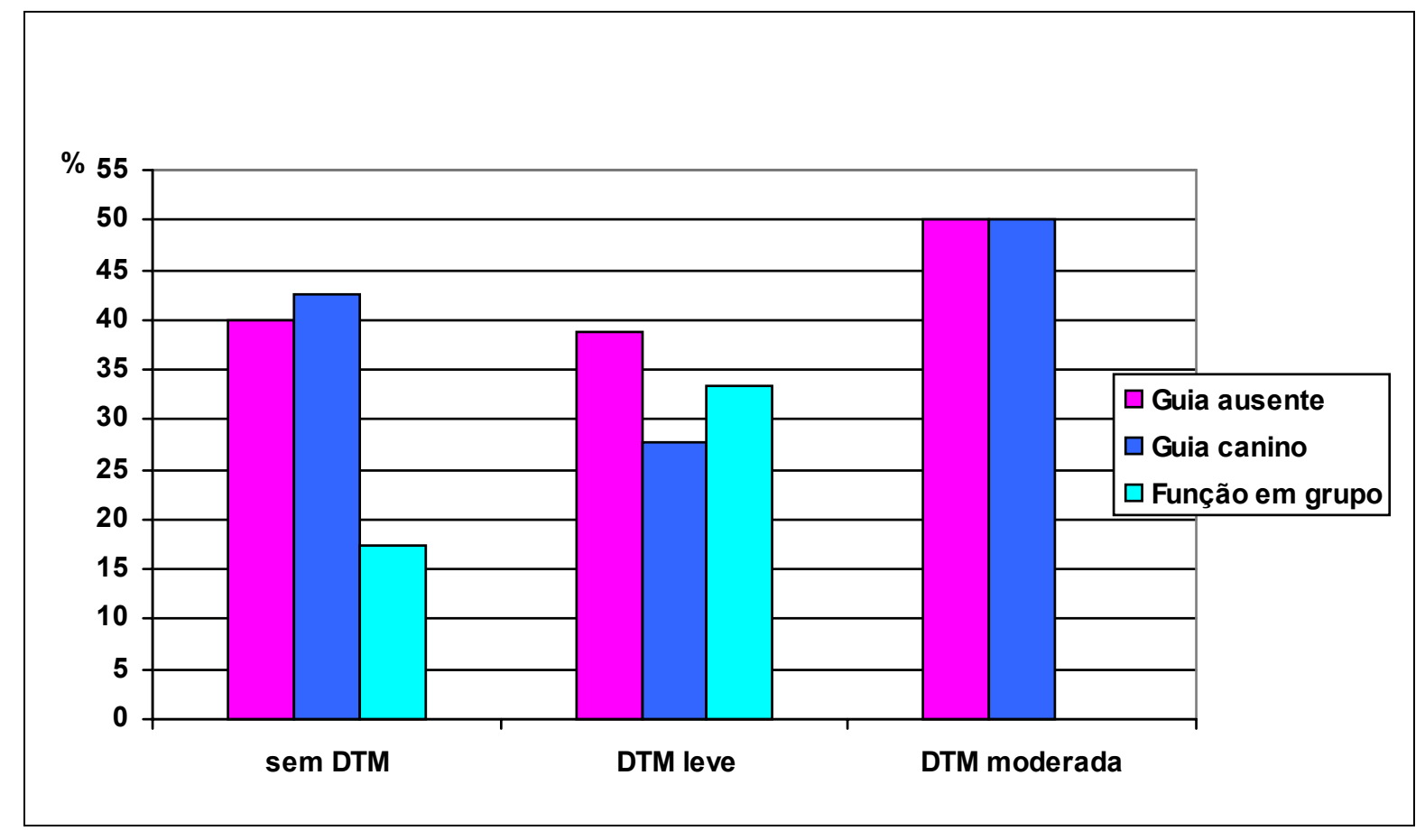

Figura 5.10: Valores percentuais dos indivíduos com diferentes padrões de lateralidade esquerda nos diferentes grupos de DTM

A presença de guia anterior também não esteve associada à presença ou severidade de DTM, na amostra estudada ( $p=0,403)$. Ver Tabela 5.14 e Figura 5.11.

Tabela 5.14: Valores absolutos e percentuais do número de indivíduos com e sem guia anterior nos diferentes grupos de DTM

\begin{tabular}{l|c|c|c|c}
\cline { 2 - 5 } & $\begin{array}{c}\text { Ausência de } \\
\text { DTM }\end{array}$ & $\begin{array}{c}\text { DTM } \\
\text { leve }\end{array}$ & $\begin{array}{c}\text { DTM } \\
\text { moderada }\end{array}$ & Total \\
\hline Guia presente & $34(85 \%)$ & $13(72,22 \%)$ & $2(100 \%)$ & $49(81,67 \%)$ \\
Guia ausente & $6(15 \%)$ & $5(27,78 \%)$ & $0(0 \%)$ & $11(18,33 \%)$ \\
TOTAL & $40(100 \%)$ & $18(100 \%)$ & $2(100 \%)$ & $60(100 \%)$ \\
\hline
\end{tabular}




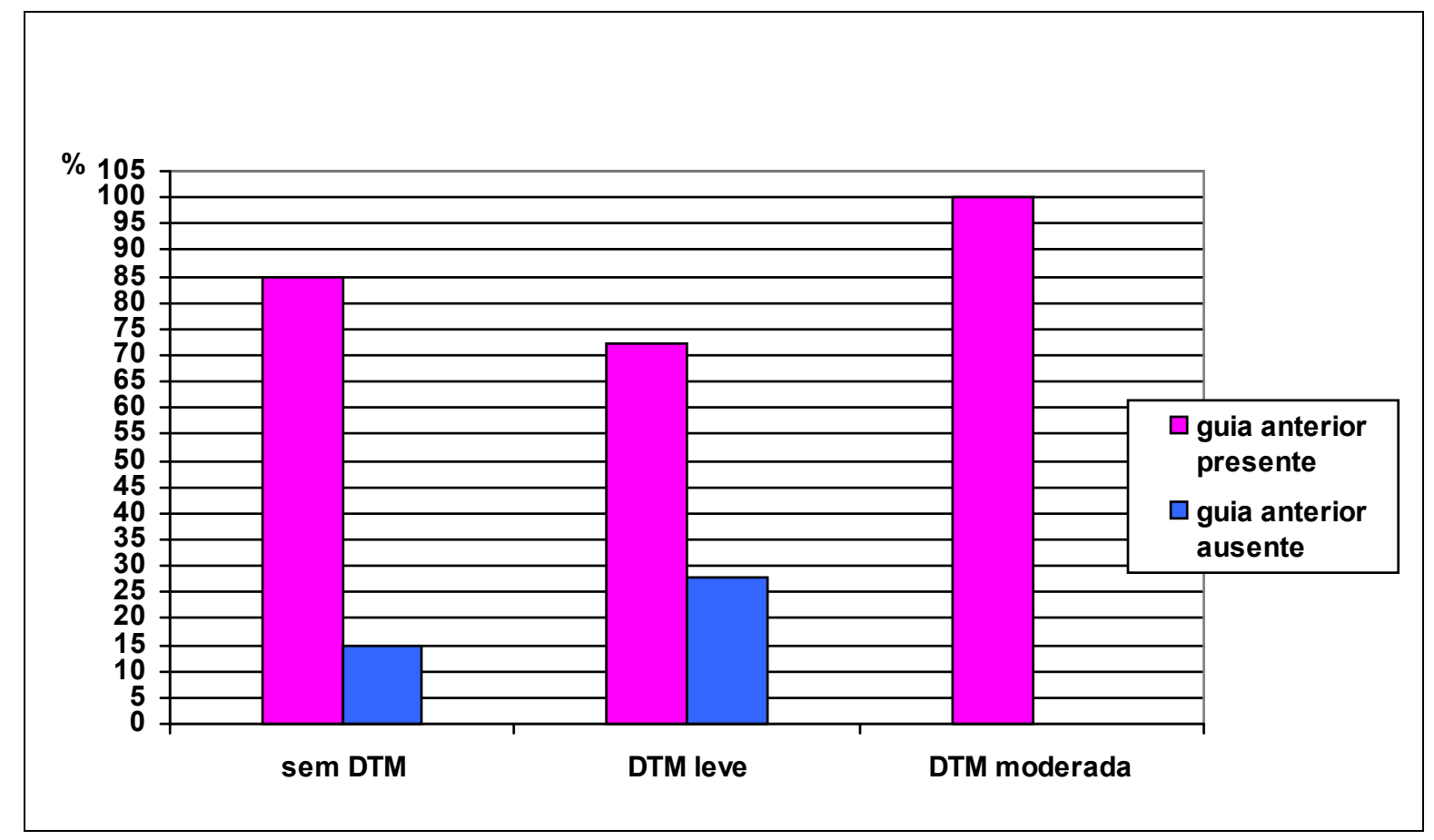

Figura 5.11: Valores percentuais dos indivíduos com e sem guia anterior, nos diferentes grupos de DTM

Não houve associação entre a presença de contatos em nãotrabalho do lado direito e a presença ou severidade de DTM ( $p=0,526)$. Tabela 5.15 e Figura 5.12.

Tabela 5.15: Valores absolutos e percentuais do número de indivíduos com diferentes padrões de contatos em não trabalho do lado direito nos diferentes grupos de DTM

\begin{tabular}{l|c|c|c|c}
\cline { 2 - 5 } & $\begin{array}{c}\text { Ausência de } \\
\text { DTM }\end{array}$ & $\begin{array}{c}\text { DTM } \\
\text { leve }\end{array}$ & $\begin{array}{c}\text { DTM } \\
\text { moderada }\end{array}$ & Total \\
\hline ausente & $35(87,5 \%)$ & $14(77,78 \%)$ & $1(50 \%)$ & $49(83,33 \%)$ \\
Presente c/guia & $2(5 \%)$ & $2(11,11 \%)$ & $0(0 \%)$ & $4(6,67 \%)$ \\
Presente s/guia & $3(7,5 \%)$ & $2(11,11 \%)$ & $1(50 \%)$ & $6(10 \%)$ \\
TOTAL & $40(100 \%)$ & $18(100 \%)$ & $2(100 \%)$ & $60(100 \%)$ \\
\hline
\end{tabular}




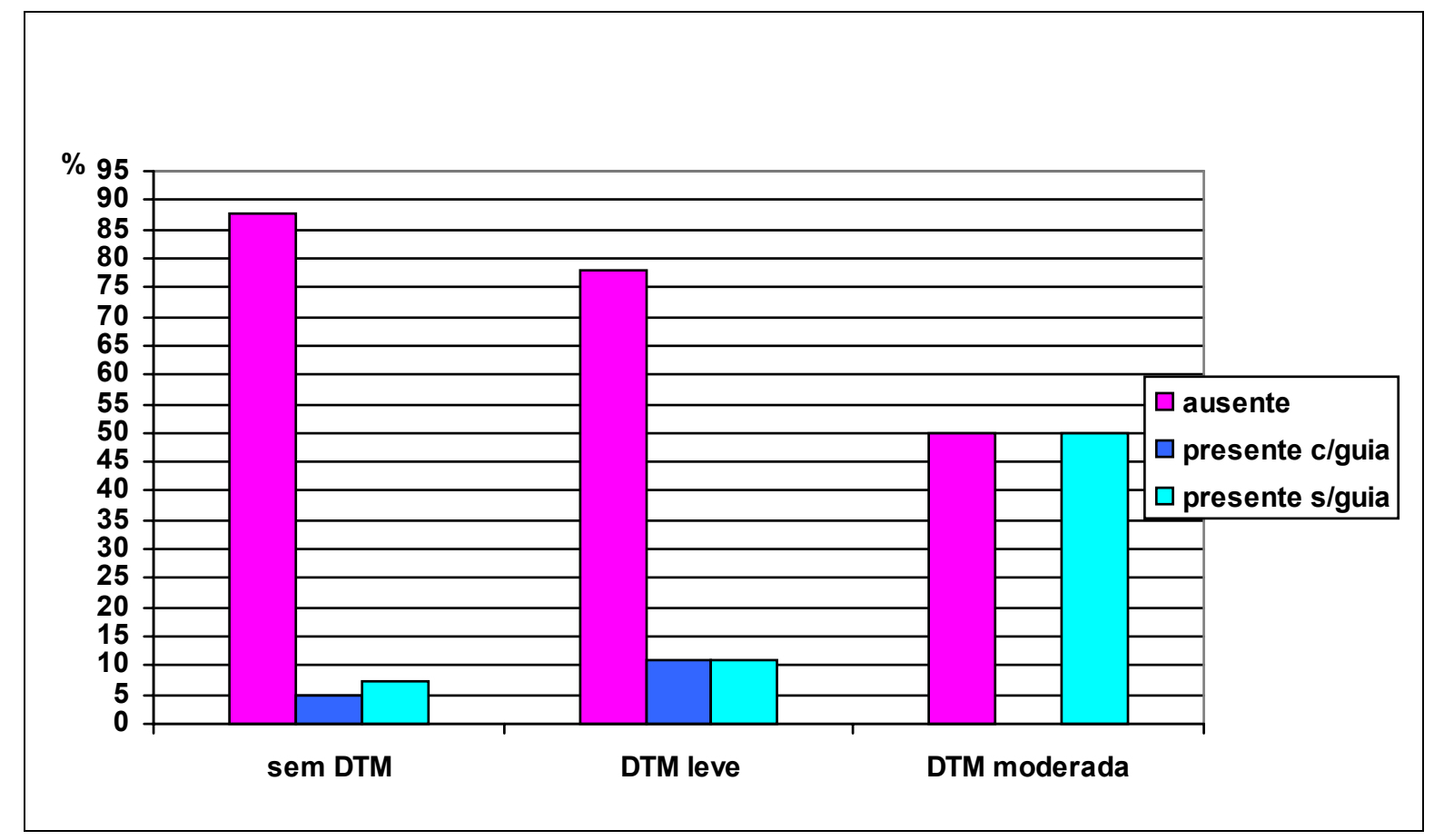

Figura 5.12: Valores percentuais dos indivíduos com diferentes padrões de contato no lado de não-trabalho direito nos diferentes grupos de DTM.

Não houve também associação entre a presença de contatos no lado de não-trabalho esquerdo e a ocorrência de sinais e/ou sintomas de DTM $(p=0,201)$. Tabela 5.16 e Figura 5.13.

Tabela 5.16: Valores absolutos e percentuais do número de indivíduos com diferentes padrões de contato em não-trabalho do lado esquerdo nos diferentes grupos de DTM.

\begin{tabular}{l|c|c|c|c}
\cline { 2 - 5 } & $\begin{array}{c}\text { Ausência } \\
\text { de DTM }\end{array}$ & $\begin{array}{c}\text { DTM } \\
\text { leve }\end{array}$ & $\begin{array}{c}\text { DTM } \\
\text { moderada }\end{array}$ & Total \\
\hline ausente & $28(70 \%)$ & $12(66,67 \%)$ & $1(50 \%)$ & $41(68,33 \%)$ \\
Presente c/guia & $8(20 \%)$ & $1(5,56 \%)$ & $1(50 \%)$ & $10(16,67 \%)$ \\
Presente s/guia & $4(10 \%)$ & $5(27,78 \%)$ & $0(0 \%)$ & $9(15 \%)$ \\
TOTAL & $40(100 \%)$ & $18(100 \%)$ & $2(100 \%)$ & $60(100 \%)$ \\
\hline
\end{tabular}




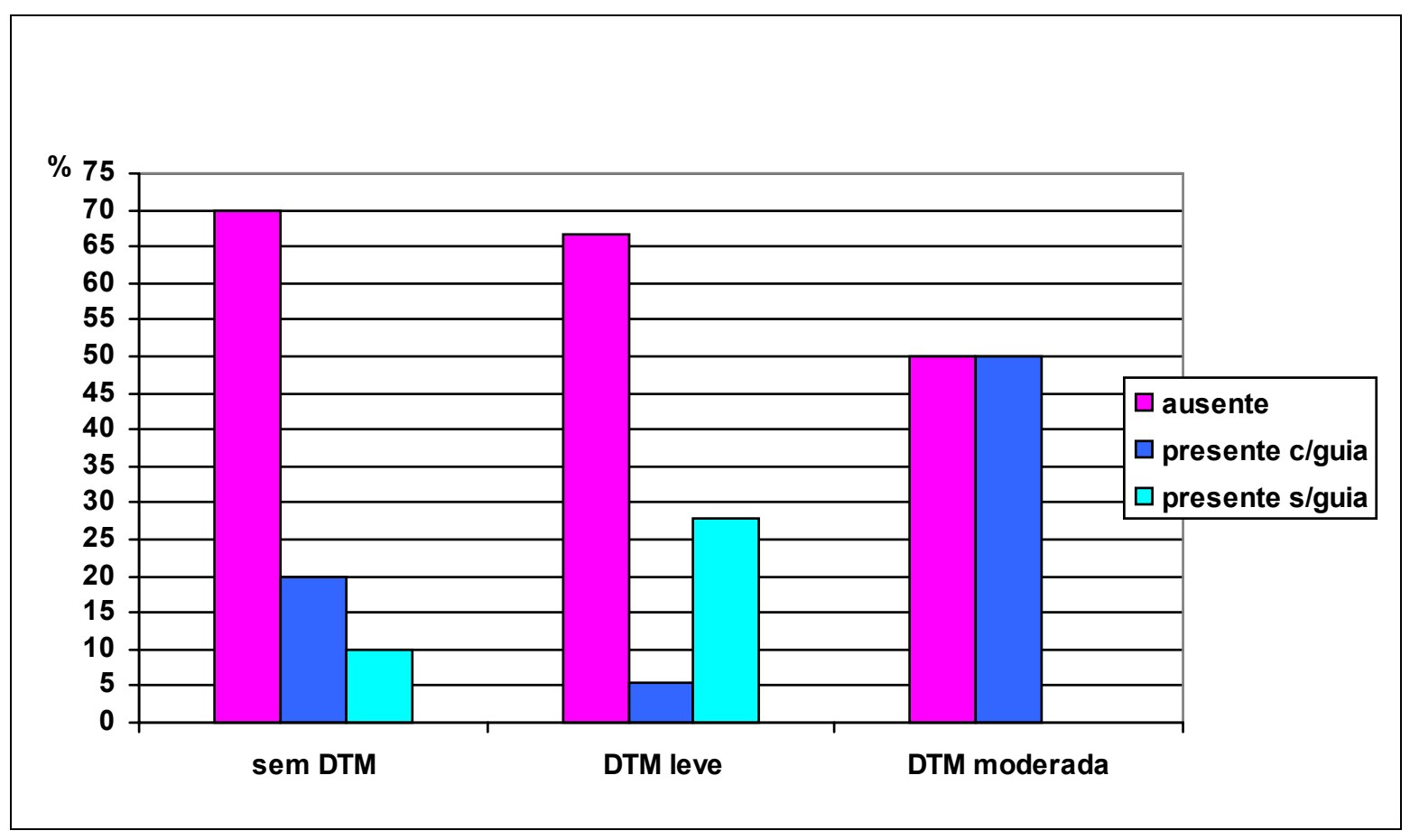

Figura 5.13: Valores percentuais dos indivíduos com diferentes padrões de contato no lado de não-trabalho esquerdo nos diferentes grupos de DTM.

\subsection{CONCENTRICIDADE CONDILAR}

Os valores médios das mensurações dos espaços articulares anterior e posterior de toda amostra, das ATMs direita e esquerda se encontram na tabela 5.17 . 
Tabela 5.17: Valores (em $\mathrm{mm}$ ) das médias e desvios padrão acompanhados dos valores máximos e mínimos dos espaços articulares anterior $(A)$ e posterior $(\mathrm{P})$, para os lados direito e esquerdo de toda a amostra

\begin{tabular}{c|c|c|c|c}
\cline { 2 - 5 } & $\begin{array}{c}(\mathbf{A}) \\
\text { direito }\end{array}$ & $\begin{array}{c}(\mathbf{P}) \\
\text { direito }\end{array}$ & $\begin{array}{c}(\mathbf{A}) \\
\text { esquerdo }\end{array}$ & $\begin{array}{c}\mathbf{( P )} \\
\text { esquerdo }\end{array}$ \\
\hline Média $\pm \mathbf{d p}$ & $1,77 \pm 0,46$ & $2,27 \pm 0,65$ & $1,85 \pm 0,39$ & $2,10 \pm 0,53$ \\
Mínimo & 1,0 & 1,3 & 1,0 & 1,0 \\
Máximo & 3,3 & 4,4 & 3,0 & 3,6 \\
\hline
\end{tabular}

Os valores médios das mensurações dos espaços articulares para as ATMs direita e esquerda foram divididos de acordo com os grupos I, II e III. Observar tabela 5.18 .

Tabela 5.18: Valores (em $\mathrm{mm}$ ) das médias e desvios padrão acompanhados dos valores máximos e mínimos dos espaços articulares anterior (A) e posterior (P), para os lados direito e esquerdo dos grupos I, II e III

\begin{tabular}{c|c|c|c|c|c|c}
\cline { 2 - 7 } & $\begin{array}{c}(\mathbf{A}) \\
\text { grupo I }\end{array}$ & $\begin{array}{c}(\mathbf{P}) \\
\text { grupo I }\end{array}$ & $\begin{array}{c}\mathbf{( A )} \\
\text { grupo II }\end{array}$ & $\begin{array}{c}\mathbf{( P )} \\
\text { grupo II }\end{array}$ & $\begin{array}{c}(\mathbf{A}) \\
\text { grupo III }\end{array}$ & $\begin{array}{c}(\mathbf{P}) \\
\text { grupo III }\end{array}$ \\
\hline Média & 1,83 & 1,94 & 1,82 & 2,42 & 1,77 & 2,19 \\
DP & 0,48 & 0,36 & 0,41 & 0,65 & 0,40 & 0,66 \\
Mínimo & 1,1 & 1,0 & 1,0 & 1,4 & 1,0 & 1,5 \\
Máximo & 3,3 & 2,6 & 2,6 & 3,9 & 2,5 & 4,4 \\
\hline
\end{tabular}

Para efeito da análise estatística e comparação entre os grupos estudados, foi considerado o lado de menor concentricidade, avaliado de acordo com os critérios já detalhados anteriormente. Os valores são expressos em percentuais, sendo $-100 \%$ o valor de posicionamento posterior absoluto, "zero" de concentricidade absoluta e 100\% de posicionamento anterior máximo. 
De acordo com o teste ANOVA a um critério, houve diferença estatisticamente significativa entre os grupos estudados (I - pré-tratamento, II - em tratamento e III - pós-tratamento) quanto à concentricidade condilar ( $p=$ 0,032 ). Após a realização do teste de Tukey para comparações múltiplas, verificou-se que houve diferença entre os grupos I (pré-tratamento) e II (em tratamento), com $p=0,034$. Ver Tabela 5.19 e Figura 5.14.

Tabela 5.19: Médias percentuais seguidas dos desvios padrão dos valores de concentricidade condilar nos grupos estudados

\begin{tabular}{|lcc|}
\hline & $\begin{array}{c}\text { Média (\%) } \pm \text { desvio } \\
\text { padrão }\end{array}$ & $p$ \\
\hline \hline I - Pré-tratamento & $0,050 \pm 18,752$ & $0,032^{*}$ \\
II - Em tratamento & $17,450 \pm 23,449$ & \\
III - Pós-tratamento & $13,550 \pm 21,693$ & \\
\hline
\end{tabular}

*estatisticamente significativo $(p<0,05)$

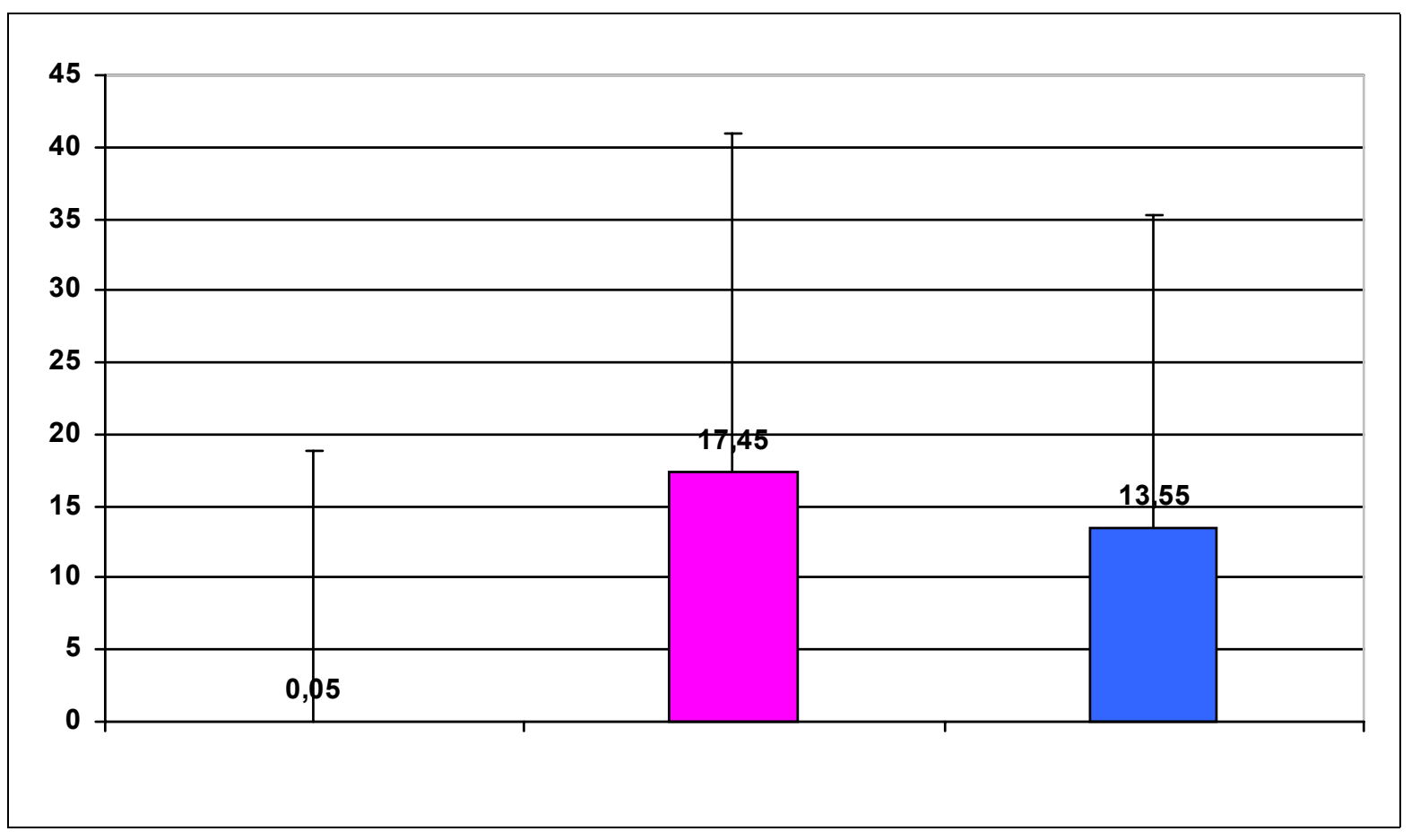

Figura 5.14: Valores percentuais e desvio-padrão da concentricidade condilar nos diferentes grupos 
O teste ANOVA a um critério também detectou diferença estatisticamente significativa entre os grupos estudados, quanto à concentricidade condilar, quando foram comparadas apenas as ATMs direitas dos indivíduos $(p=0,035)$. Segundo o teste de Tukey para comparações múltiplas, houve diferença apenas entre os grupos I (prétratamento) e II (em tratamento), com $p=0,035$. Ver Tabela 5.20 e Figura 5.15.

Tabela 5.20: Médias percentuais seguidas dos desvios padrão dos valores de concentricidade condilar nos grupos estudados, considerando-se apenas as ATMs direitas

\begin{tabular}{lcc}
\hline & Média (\%) \pm desvio padrão & $p$ \\
\hline I - Pré-tratamento & $2,300 \pm 15,553$ & \\
II - Em tratamento & $16,950 \pm 22,013$ & $0,035^{*}$ \\
III - Pós-tratamento & $13,450 \pm 16,008$ & \\
\hline *estatisticamente significativo $(\mathrm{p}<0,05)$ &
\end{tabular}

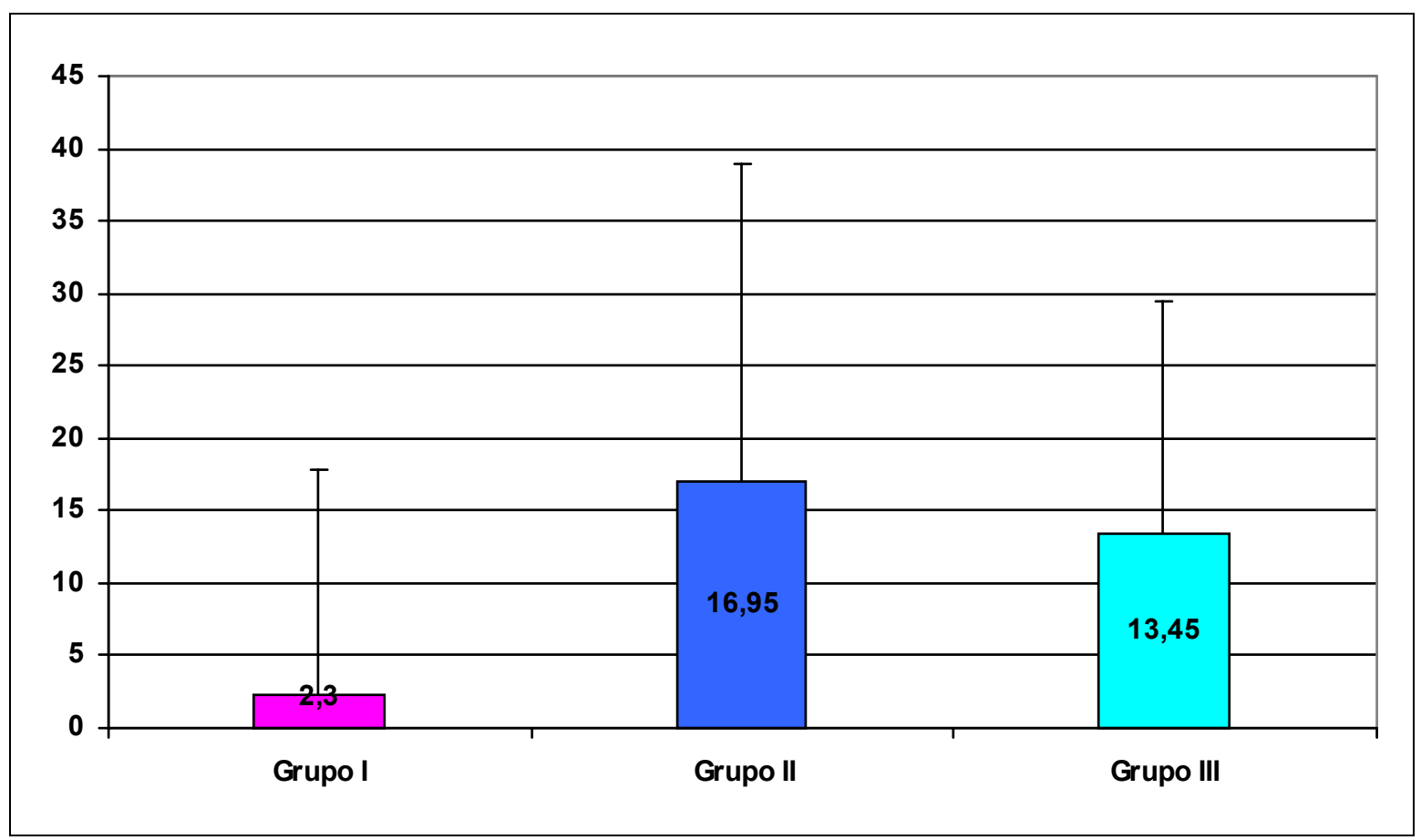

Figura 5.15: Médias de concentricidade condilar nos diferentes grupos, considerando-se apenas as ATMs direitas 
Considerando-se apenas as ATMs esquerdas dos indivíduos, o teste ANOVA a um critério não detectou diferença estatisticamente significativa entre os grupos estudados, quanto à concentricidade condilar ( $p$ $=0,293)$. Ver Tabela $5 \cdot 21$.

Tabela 5.21: Médias percentuais seguidas dos desvios padrão dos valores de concentricidade condilar nos grupos estudados, considerando-se apenas as ATMs esquerdas

\begin{tabular}{lcc}
\hline & Média $(\%) \pm$ desvio padrão & $p$ \\
\hline I - Pré-tratamento & $3,050 \pm 14,449$ & \\
II - Em tratamento & $9,850 \pm 12,897$ & 0,293 \\
III - Pós-tratamento & $3,650 \pm 17,406$ & \\
\hline
\end{tabular}

Não houve diferença estatisticamente significativa entre os valores de concentricidade esquerda e direita (médias e desvio-padrão de 10,9/18,7 e 5,9/15,3, respectivamente), quando aplicado o teste t de Student $(p=0,109)$ (Figura 5.16).

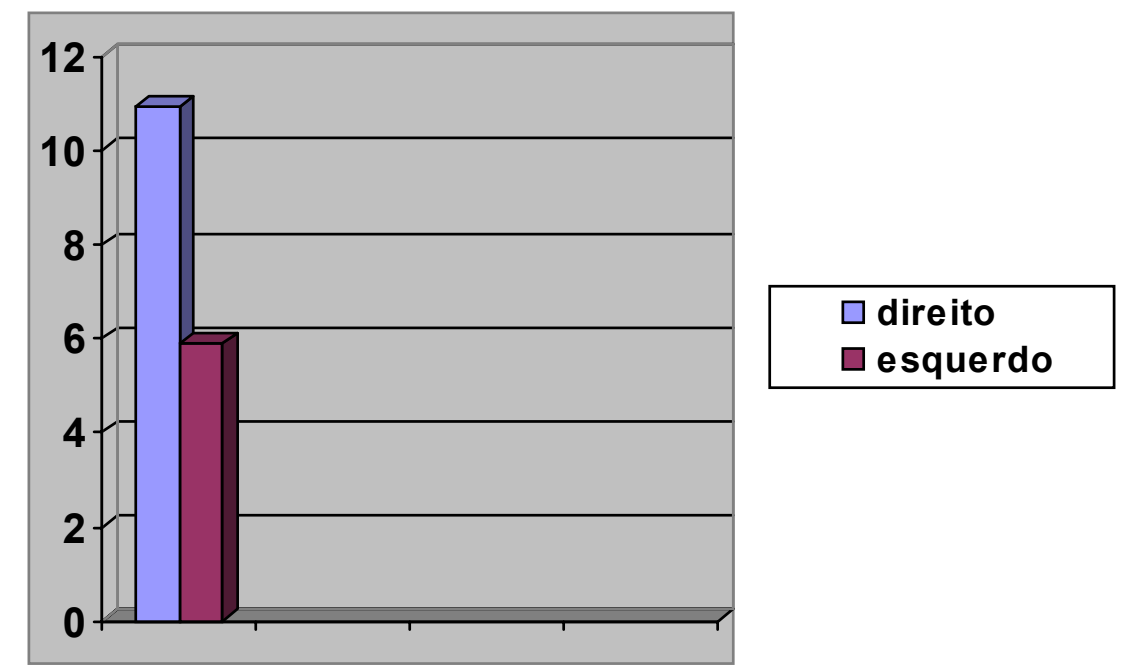

Figura 5.16: Concentricidade condilar dos lados direito e esquerdo 
Quando os grupos foram comparados, quanto ao espaço articular superior, (ATMs direitas e esquerdas), o teste ANOVA a um critério não detectou diferença estatisticamente significativa $(p=0,298$ e $p=0,249))$. Ver Tabela 5.22 e 5.23.

Tabela 5.22: Médias (em $\mathrm{mm}$ ) seguidas dos desvios padrão dos valores dos espaços articulares superiores nos grupos estudados (lado direito).

\begin{tabular}{lcc}
\hline & Média $(\mathrm{mm}) \pm$ desvio & $\mathrm{p}$ \\
& padrão & \\
\hline I - Pré-tratamento & $2,45 \pm 0,55$ & \\
II - Em tratamento & $2,73 \pm 0,68$ & 0,298 \\
III - Pós-tratamento & $2,46 \pm 0,7$ & \\
\hline
\end{tabular}

Tabela 5.23: Médias (em $\mathrm{mm}$ ) seguidas dos desvios padrão dos valores dos espaços articulares superiores nos grupos estudados (lado esquerdo)

\begin{tabular}{lcc}
\hline & $\begin{array}{c}\text { Média }(\mathrm{mm}) \pm \text { desvio } \\
\text { padrão }\end{array}$ & $\mathrm{p}$ \\
\hline I - Pré-tratamento & $2,46 \pm 0,73$ & \\
II - Em tratamento & $2,66 \pm 0,62$ & 0,249 \\
III - Pós-tratamento & $2,37 \pm 0,45$ & \\
\hline
\end{tabular}

Não houve correlação entre a soma total dos valores do questionário anamnésico que compuseram o índice de DTM e a concentricidade condilar para toda a amostra (Coeficiente de Spearman = $0,197)(p>0,05)$ (Figura 5.17). 


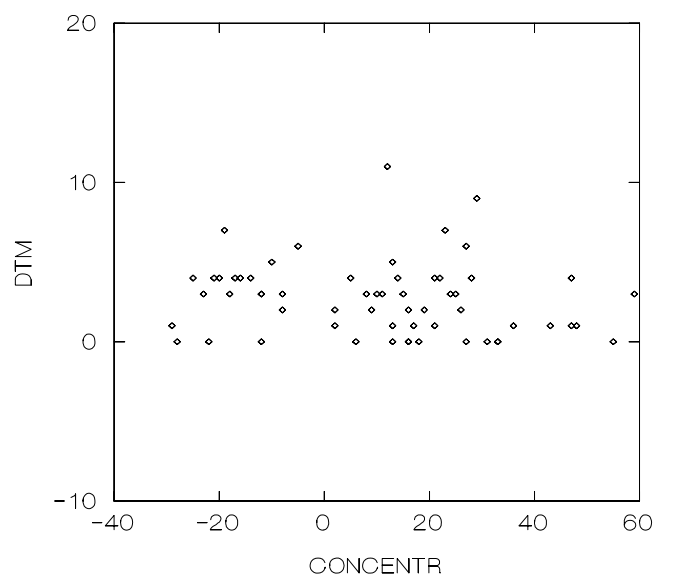

Figura 5.17: Correlação entre a concentricidade condilar e o índice de DTM 
6- Discussão 


\section{6- DISCUSSÃO}

Os aspectos oclusais foram considerados os principais fatores etiológicos das Disfunções Temporomandibulares, por muito tempo. Apesar do grande número de publicações atuais pertinentes a esta área, considerando limitada a participação dos mesmos na etiologia das DTMs, a controvérsia ainda permanece em relação à real participação desses fatores como agentes causadores de problemas articulares e musculares. Essa controvérsia influenciou e incentivou a classe ortodôntica a buscar respostas claras sobre a relação entre a ortodontia e as DTMs, instigada pelo grande número de processos judiciais que creditavam ao tratamento ortodôntico a causa do desenvolvimento das DTMs na metade da década de 80 . Nesta época surgiram alguns questionamentos: se o tratamento ortodôntico causava, curava, ou não alterava o quadro das DTMs.

Se o tratamento ortodôntico realmente pudesse aumentar a incidência de sinais e sintomas de DTM na população tratada, surgiria então uma nova questão: $O$ tipo de técnica ou de dispositivos ortodônticos deveria ser considerado?

Neste âmbito encontram-se os aparelhos ortopédicos funcionais, que agem modificando a função, para que a forma seja corrigida. No caso do Bionator, a construção do aparelho em uma posição anteriorizada da mandíbula ocasionaria uma alteração da posição condilar e da relação côndilo-disco. A manutenção da posição condilar concêntrica nas fossas mandibulares é defendida por alguns autores ${ }^{125,133}$, que a consideram importante para a normalidade da ATM. Em contrapartida, PULLINGER et al. ${ }^{96}$ alegam que a ausência de concentricidade condilar não está associada ao aparecimento de sinais e sintomas de DTM, devido a grande variabilidade nesse posicionamento encontrada em indivíduos assintomáticos. 
Por muitos anos, a ciência odontológica baseou-se em achados morfológicos para explicar a ocorrência de dores e disfunções do sistema estomatognático. Nesse contexto, pacientes portadores de DTM eram avaliados primariamente em relação ao relacionamento oclusal e ao posicionamento condilar na fossa. A coexistência dessas variáveis, ou seja, côndilos não concêntricos e/ou má oclusão com sintomas de DTM, levou os clínicos a executar procedimentos, muitas vezes irreversíveis, na tentativa de corrigir a alteração morfológica. Dessa maneira, pensava-se, então, estar sanado o problema da dor e disfunção.

A concentricidade era vista dessa forma, ou seja, seria extremamente necessária para propiciar um relacionamento harmonioso entre as estruturas articulares. Assim, compressões de estruturas sinoviais, capsulares ou retrodiscais poderiam estar associadas a posições ectópicas do côndilo na fossa. Os deslocamentos de disco articular ainda fariam parte desse cenário, como uma possível manifestação patológica de côndilos excêntricos.

Todas essas afirmações tornam-se importantes quando pacientes submetidos a protrusão mandibular ortopédica são considerados. Esses pacientes são mantidos, durante o período de tratamento, com os côndilos totalmente fora da chamada "posição ortopedicamente estável"79 dos côndilos na fossa, contrariando todos os conceitos gnatológicos de relacionamento oclusal e condilar, o que poderia gerar dor e disfunção.

Apesar dessas suposições, o real efeito de uma alteração morfológica (a posição condilar) nas dores relatadas pelos pacientes ainda é uma incógnita.

O avanço no entendimento dos mecanismos de transmissão das dores orofaciais, incluindo as DTMs, tem ajudado pesquisadores e clínicos a melhor compreender a evolução dos sintomas dos pacientes. Isso fez com que se passasse a analisar tais processos aplicando-se um modelo 
bio-psicossocial, desconsiderando-se o aspecto meramente mecanicista da doença.

Baseado nessas afirmações, esse estudo propôs-se a avaliar a posição condilar em indivíduos submetidos a protrusão mandibular ortopédica e qual a relação com as diferentes manifestações de DTM.

Os métodos de avaliação utilizados nessa pesquisa incluíram um questionário anamnésico, exame físico de movimentação mandibular e palpação muscular e da ATM, além de avaliação radiográfica das ATMs dos indivíduos nos três diferentes grupos.

Tais métodos, seja em estudos epidemiológicos ou em trabalhos de eficácia de terapias, ainda são motivo de controvérsia. Apesar de haver vários índices e questionários estudados e validados disponíveis na literatura, problemas de formulação e interpretação dos achados ainda representam barreiras para a utilização sistemática da maioria deles.

A utilização de um índice anamnésico, associada à execução de exames objetivos, como a palpação padronizada e calibrada, parece expressar, de forma realista, a presença de sinais e sintomas das DTMs.

Quando a amostra foi avaliada em relação aos movimentos mandibulares, já que uma limitação em tais movimentos poderia sugerir um problema de interferência do disco articular, os valores obtidos das médias de abertura bucal, lateralidade direita e esquerda, e protrusão foram de $48,6 \mathrm{~mm}, 8,8 \mathrm{~mm}, 8,77 \mathrm{~m}$ e 7,73mm. Esses valores são compatíveis com a normalidade, sendo o valor de abertura bucal (média $=48,6 \mathrm{~mm}$ ) muito semelhante ao valor encontrado por CONTI et al. ${ }^{16}$ de $48,2 \mathrm{~mm}$, em seu trabalho avaliando 200 pacientes tratados e não tratados ortodonticamente, apresentando má oclusão de Classe I ou II.

Essa informação do grau de abertura bucal é um dado objetivo bastante utilizado na análise dos problemas relacionados à ATM. Devido 
aos valores se aproximarem dos valores de indivíduos normais, parece que a protrusão mandibular não predispõe a essas alterações intra-articulares.

Os movimentos de lateralidade também são indicativos de alteração muscular e/ou articular quando os valores são inferiores a $7 \mathrm{~mm}^{35}$. Esse fato não ocorreu no presente estudo, em que os valores dos movimentos de lateralidade direita e esquerda foram em média de $8,8 \mathrm{~mm}$ e $8,77 \mathrm{~mm}$, respectivamente, considerados dentro do limite de normalidade e similares aos valores de $9 \mathrm{~mm}$ e $8,7 \mathrm{~mm}$, citados em outro estudo ${ }^{124}$. A média para o movimento protrusivo de $7,73 \mathrm{~mm}$ desse estudo também foi semelhante aos $6,9 \mathrm{~mm}$ citados pelos mesmos autores ${ }^{124}$.

Esses achados demonstram que mesmo pacientes com côndilos anteriorizados continuam a executar uma movimentação mandibular normal, indicando, provavelmente, uma relação côndilo-discofossa normal. Tal informação, no entanto, não pôde ser comprovada no presente estudo, pois não foram realizadas imagens de ressonância magnética, em que o posicionamento do disco articular poderia ser observado de forma clara.

A média dos trespasses horizontal e vertical foi de $3,77 \mathrm{~mm}$ e $2,77 \mathrm{~mm}$, respectivamente. O valor médio do trespasse horizontal não se apresentou tão aumentado para uma amostra de pacientes com má oclusão de Classe II devido a esse valor representar toda a amostra, considerando também indivíduos já tratados dessa mesma má oclusão. Esses valores acima citados aproximaram-se dos valores encontrados por SELIGMAN; PULLINGER ${ }^{115}$ em amostras de pacientes assintomáticos, assim como também foram similares aos valores de $2,95 \mathrm{~mm}$ e $2,66 \mathrm{~mm}$ de FONSECA $^{29}$, em amostras de pacientes sintomáticos.

Os valores do trespasse horizontal apresentam-se como um dado relevante no que diz respeito à prevalência de DTM, pois um trespasse horizontal maior que $6-7 \mathrm{~mm}$ foi considerado como fator oclusal de risco no 
desenvolvimento das DTMs ${ }^{72}$. Em relação a esse dado, a média obtida de $3,77 \mathrm{~mm}$ não representa um risco para esses pacientes.

Quando o número de contatos em MIH foi verificado, encontrou-se um valor médio de 7,53 contatos, semelhantes aos 6,2 citados na literatura ${ }^{124}$. O maior número de contatos oclusais para o grupo póstratamento era esperado e pode ser creditado à utilização de terapia ortodôntica fixa, com a finalidade de correção pós-ortopédica, em que freqüentemente, há ocorrência de mordida aberta posterior.

A presença de facetas de desgastes também foi considerada; de toda a amostra, 56,67\% apresentaram-se sem facetas e 43,33\% mostraram-se com a presença dessas facetas. Como a presença dessas facetas de desgaste tem sido vinculada às Disfunções Temporomandibulares, analisaram-se, estatisticamente, essas duas variáveis. De acordo com os resultados da tabela 5.7, não houve associação estatisticamente significante entre a presença de facetas e o grau de DTM. Tal fato deve ser analisado com cautela, pelo fato da amostra não ter sido previamente estratificada para essa variável. Apesar disso, a presença de facetas de desgaste tem sido considerada como um processo adaptativo em pacientes que fazem parafunção noturna. Tal adaptação poderia estar associada ao aspecto assintomático desses pacientes.

$\mathrm{Na}$ avaliação da presença de mordida aberta anterior, apenas $10 \%$ de toda a amostra apresentavam essa má oclusão. Quando a presença de DTM foi relacionada com essa má oclusão, não se estabeleceu uma associação significante do ponto de vista estatístico. Os únicos dois indivíduos da amostra que foram classificados com DTM moderada não apresentavam mordida aberta anterior (tabela 5.8). Esses dados também devem ser observados com cautela já que apenas seis jovens apresentavam essa má oclusão.

De acordo com MCNAMARA JUNIOR; SELIGMAN; OKESON ${ }^{72}$ a mordida aberta esquelética está associada a artropatias, sendo essa má 
oclusão considerada um fator de risco para as Disfunções Temporomandibulares. Não deve ser esquecido, no entanto, que essa alteração pode ser o resultado de alterações ósseas e ligamentosas da ATM, como as doenças degenerativas, por exemplo. Ressalte-se que esses autores especificaram a mordida aberta esquelética, sugerindo, assim, um grau de severidade acentuado para essa má oclusão, diferentemente do nosso estudo, que apenas classificou os jovens com presença ou ausência de mordida aberta, desconsiderando sua severidade. Entretanto, a mordida aberta não pode ser considerada isoladamente um fator etiológico das DTMs $^{95}$. Quando não tratada, pode dificultar a mastigação devido à ausência de guia anterior, mas somente associada a outros fatores poderia aumentar o risco de DTM.

A mordida cruzada unilateral, também indicada como fator de risco para as DTMs ${ }^{12,72}$, foi avaliada nessa pesquisa. Observando os dados obtidos, 95\% de toda amostra não apresentaram essa má oclusão, que também não foi relacionada à prevalência de DTM (tabela 5.9). Esse achado corrobora com o trabalho de RUNGE et al. ${ }^{106}$, que também não encontraram associação entre a presença de mordida cruzada posterior e as DTMs; entretanto, como não foi o objetivo primário do presente estudo, esse resultado deve ser observado com cautela. Deve ser ressaltado que tais más oclusões, quando encontradas em pacientes com sintomas de DTM, podem ser a conseqüência de processos intra-articulares e não a causa dos mesmos. O aspecto destrutivo das doenças degenerativas exemplifica tal afirmação.

Vários estudos têm sido realizados com a finalidade de comparar indivíduos com má oclusão com grupos controle de oclusão normal, para tentar elucidar a participação das más oclusões na etiologia das DTMs. Algumas características oclusais freqüentemente encontradas na Classe II aumentam as possibilidades de sinais e sintomas de DTM ${ }^{44,45}$. Como já foi relatado anteriormente, um trespasse horizontal acentuado, 
característica das más oclusões de Classe II, pode ser considerado um fator de risco de $D_{T M}^{72}$

No presente trabalho não se encontrou uma relação entre diferentes relações sagitais e a presença de DTM. Dos 60 participantes da amostra, 23 apresentavam relação de Classe I, 31 de Classe II até meia cúspide e apenas seis indivíduos apresentavam uma relação mais severa de Classe II. Apesar dessa amostra ser representada por pacientes Classe II ou Classe I que já foram tratados, a prevalência de DTM não diferiu de outros estudos.

Por vários anos a discrepância das posições de RC e MIH sustentou a teoria oclusal de etiologia das DTMs. Variações entre essas posições de até $2 \mathrm{~mm}$ foram constatadas em 93,3\% da amostra, e 6,67\% dos indivíduos exibiram diferenças entre essas posições de 2 a $4 \mathrm{~mm}$. Levandose em consideração que apenas discrepâncias maiores que $4 \mathrm{~mm}$ dobrariam as chances de se desenvolver $\mathrm{DTM}^{72}$, e que nesse estudo não se detectaram variações dessa ordem, os resultados obtidos mostrando uma não associação entre essa variável e a prevalência de DTM podem ser justificados.

A presença e o tipo de guia lateral foram estudados nos indivíduos da amostra, em ambos os lados. Para o lado direito, 33,3\% da amostra apresentaram guia canino, 21,6\% função em grupo e em 45\% dos indivíduos foi observada a ausência de guia. Esses mesmos valores para o lado esquerdo foram de 38,3\%, 21,6\% e 40\%, respectivamente. Quando se comparou a presença de guia de desoclusão com a presença e severidade de DTM, não se demonstrou uma associação estatística. Esse dado corrobora com trabalhos prévios $^{108,109}$, confirmando a pequena participação dos fatores oclusais na etiologia das DTMs. Embora a presença de guia de desoclusão faça parte dos princípios para obtenção de uma oclusão funcional ideal tão defendida por $\mathrm{OKESON}^{79}$, parece que a ausência desses princípios oclusais podem ser fatores potencialmente importantes na 
manifestação de patologias de origem oclusal do que no desencadeamento de sinais e sintomas de DTM.

A participação da presença de guia lateral pelo canino nas DTMs tem sido bastante questionada. Para alguns autores ${ }^{58}$, em casos de patologias estritamente articulares de DTM, guias efetivas devem ser evitadas como parte do tratamento. Ainda: em trabalho recente ${ }^{111}$ não se encontrou diferença na diminuição da dor em pacientes que usaram placas com ou sem desoclusão pelo canino.

A guia anterior também foi avaliada, sendo considerada efetiva em $81,6 \%$ da amostra, porém não houve relação com a presença ou severidade de DTM. Esse valor foi similar aos $79 \%$ citados por VALLECOROTTI et al. ${ }^{124}$, que encontraram associação estatisticamente significante entre essas variáveis, ou seja, os jovens que não apresentavam guia anterior estavam com maior freqüência no grupo com DTM leve e moderada.

Os contatos no lado de não-trabalho, historicamente apontados como fatores desencadeadores de desordens da ATM, foram investigados. As tabelas 5.15 e 5.16 ilustram os indivíduos com contatos no lado de nãotrabalho direito e esquerdo, respectivamente, nos 60 jovens que compõem a amostra. Para o lado direito encontrou-se uma porcentagem de $83,3 \%$ da amostra com ausência dessas interferências, 6,67\% com contatos no lado de não-trabalho mantendo a guia e 10\% com esses contatos, porém sem a guia. Para o lado esquerdo, a ausência desses contatos foi verificada em $68,3 \%$ da amostra; $16,6 \%$ apresentavam os contatos com guia e $15 \%$ sem guia. O dado mais importante se refere à não associação entre a presença dessas interferências no lado de não-trabalho e a prevalência de DTM. Essa não associação entre as interferências e as DTMs talvez se explique devido à capacidade adaptativa do sistema mastigatório à situação oclusal, como comentada por INGERVALL; CARLSSON ${ }^{51}$, apesar de outros autores encontrarem resultados contrastantes acreditando nessa associação ${ }^{12}$. 
De acordo com os resultados obtidos com o questionário anamnésico, 66,67\% da amostra apresentaram-se com ausência de DTM, 30\% com DTM leve, enquanto apenas 3,33\% foram classificados com DTM moderada. Com a utilização desse questionário, nenhum indivíduo da amostra foi considerado como apresentando DTM severa. Tais valores foram obtidos de acordo com o índice proposto e modificado por diversos autores $^{18,29,39,40}$, com o objetivo de facilitar a classificação de uma amostra em relação à presença e severidade de DTM.

Apesar da dificuldade em se classificar os indivíduos com e sem DTM, a padronização na utilização do questionário anamnésico tem auxiliado na obtenção de resultados mais confiáveis. Essa classificação não define a necessidade de tratamento, já que o grande número de indivíduos que apresentam sinais e sintomas de DTM nem sempre precisam ser tratados $^{18,29}$.

Os valores de prevalência de DTM desse estudo foram próximos aos encontrados por CONTI et al. ${ }^{16}: 62,5 \%$ com ausência de DTM, $34 \%$ com DTM leve e 3,5\% com DTM moderada.

Quando se comparou a presença e severidade de DTM entre os três grupos, não se encontrou uma diferença estatisticamente significante entre eles. Se a prevalência de DTM nos três grupos foi similar, o fato dos indivíduos estarem em tratamento com terapia de avanço mandibular ou mesmo de já terem finalizado esse tratamento não aumenta as chances dos mesmos apresentarem sintomas de DTM. De acordo com esses resultados, os côndilos não necessariamente precisariam estar concêntricos nas fossas mandibulares para caracterizar uma condição de normalidade nas articulações.

Sabe-se que a faixa etária da amostra em questão não é aquela em que se encontra a maior parte dos pacientes de DTM. Esse fato pode explicar porque nenhum indivíduo foi considerado com "disfunção severa". Ainda: mesmo aqueles em tratamento, apesar da mudança de 
posição do côndilo (como será discutido posteriormente), não apresentaram queixas de dor. Esse dado também reflete o que normalmente se encontra na prática ortodôntica, em que é ínfimo o porcentual de pacientes que se queixam de dor com a utilização de aparelhos protrusivos.

Esse questionário anamnésico, no entanto, não é capaz de diferenciar os diversos sub-tipos de DTM quando presentes. Muita importância tem sido dada a esse detalhe, desde que propostas terapêuticas são completamente distintas para casos de distúrbios musculares ou articulares.

Com o objetivo de se complementar a análise da amostra palpação muscular e da ATM também foram executadas. Apesar da suposta subjetividade do exame de palpação, tem sido demonstrado que após um programa de calibração e treinamento, tal procedimento pode ser um parâmetro confiável para comparação entre indivíduos ou entre diferentes amostras, como neste trabalho.

Com a terapia de avanço mandibular e deslocamento do côndilo das fossas mandibulares, aventou-se a hipótese de desencadeamento de dor e ruídos articulares. Quando os valores obtidos durante o exame de palpação das ATMs foram comparados entre os grupos I, II e III, não foram encontradas diferenças entre eles, ou seja, a sensibilidade à palpação das ATMs foi similar, independente dos indivíduos se encontrarem com os côndilos terapeuticamente mais anteriorizados ou não. A freqüência de, pelo menos, um ponto sensível nos aspectos lateral e posterior das ATMs bilateralmente foi de $20 \%$ para o grupo I, $35 \%$ para o II e $35 \%$ para o grupo III. Apesar do ligeiro aumento nessa freqüência nos grupos II e III em relação ao I, esse aumento não foi estatisticamente significante.

Já a sensibilidade à palpação muscular, considerada como o sinal mais comum em estudos epidemiológicos, pode ser usada como recurso diagnóstico na detecção de $\mathrm{DTM}^{119}$. 
Como salientado anteriormente, outro fator também supostamente relacionado à protrusão mandibular seria a presença de dores na musculatura mastigatória devido a um posicionamento anormal da mandíbula.

Quando se considerou a freqüência de pontos sensíveis na musculatura mastigatória entre os grupos I, II e III, os resultados mostraram uma similaridade destes valores entre os grupos.

HENRIKSON; NILNER; KUROL ${ }^{46}$, em estudo longitudinal onde pacientes tratados ortodonticamente de má oclusão de Classe II foram comparados a uma amostra com a mesma má oclusão não tratada e um grupo controle de oclusão normal, relataram uma melhora na sensibilidade muscular.

Já PANCHERZ ${ }^{84}$, avaliando os efeitos do aparelho Herbst em pacientes Classe II, relatou que o número de pacientes com sensibilidade à palpação muscular dobrou nos três primeiros meses de uso do aparelho, apesar desses sintomas praticamente desaparecerem ao final do tratamento.

Os resultados dessa pesquisa não corroboram com os achados do estudo acima, talvez devido ao tipo de aparelho utilizado por esses autores que é fixo, ou seja, de uso contínuo, em comparação com o Bionator utilizado em nosso estudo, que permite a sua remoção e utilização intermitente.

Essa hipótese de aumento na sensibilidade muscular em pacientes tratados com avanço mandibular não é um fato comumente encontrado clinicamente. Mecanismos de adaptação muscular (mioplasticidade) diante de novas posições mandibulares têm sido descritos na literatura. SFONDRINI et al. ${ }^{116}$ relataram um aumento de fibras musculares resistentes à fadiga e diminuição de fibras sensíveis à fadiga em experimento de protrusão mandibular em ratos. Esses autores sugeriram 
que tal evento também poderia acontecer em humanos, o que explicaria a baixa freqüência de dores musculares em pacientes tratados com ortopedia. Dessa forma, parece-nos que a utilização de aparelhos de protrusão mandibular não aumentaria o risco de surgimento de sinais e sintomas de DTM. Parece que imediatamente após a instalação de aparelhos propulsivos fixos, há um aumento na atividade postural do músculo pterigóideo lateral ${ }^{49}$, porém após aproximadamente quatro meses, os níveis de atividade muscular retornam aos valores normais prévios ao tratamento. Esse período inicial talvez reflita o curso do processo adaptativo já descrito anteriormente.

A concentricidade condilar foi outro parâmetro avaliado na presente pesquisa. O posicionamento condilar tem sido historicamente considerado um dos critérios para se diagnosticar e tratar pacientes com sinais e sintomas de DTM.

A relação entre a concentricidade condilar e os desarranjos internos da ATM tem sido discutida, sendo que alguns autores ${ }^{125,133}$ creditam à ausência de concentricidade condilar, causada pelo mau posicionamento dos côndilos, um papel importante no desencadeamento de desordens intraarticulares.

Nesse contexto, a realização de procedimentos ortodônticos que possam interferir nesse relacionamento côndilo-fossa-disco torna-se potencialmente preocupante. WYATT ${ }^{140}$ apontou a utilização de elásticos intermaxilares, mentoneiras e a retração dos incisivos superiores como procedimentos de risco para desencadear processos intra-articulares, devido à posteriorização dos côndilos. Em contrapartida, trabalhos que avaliaram a posição condilar em pacientes tratados ortodonticamente foram realizados e não confirmam a hipótese acima ${ }^{32,33,60,64,65}$. Para aumentar a controvérsia, CARLTON; NANDA ${ }^{10}$, quando avaliaram pacientes tratados ortodonticamente, relataram uma melhora na concentricidade condilar após o término da terapia. 
Dentre esses procedimentos ortodônticos de risco para as ATMs, os tratamentos ortopédicos de correção das discrepâncias sagitais de Classe II, com avanço postural da mandíbula, têm papel de destaque. Essa terapia leva à alteração da posição mandibular, deslocando os côndilos anteriormente ao seu assentamento fisiológico nas fossas mandibulares. Se realmente os côndilos se mantêm anteriorizados ao final do tratamento, a importância desse posicionamento condilar para a saúde das ATMs é fator a se considerar. À luz dos conceitos atuais, a grande variabilidade da posição condilar encontrada em indivíduos assintomáticos e as dificuldades de mensuração desse posicionamento em técnicas radiográficas comuns causam dúvida quanto à relevância dessa informação, tanto para se diagnosticar, como para tratar ou até mesmo prevenir DTMs.

Com o intuito de melhorar a confiabilidade da avaliação da posição condilar, técnicas radiográficas foram comparadas, principalmente as transcranianas e as tomografias. De acordo com MONGINI ${ }^{73}$ e MUTO et al. $^{76}$, as TRs são importantes no diagnóstico das DTMs, porém em algumas situações devem ser requisitadas em conjunto com as tomografias para obtenção de resultados mais confiáveis ${ }^{93}$.

A superioridade das imagens tomográficas é indiscutível, porém a técnica radiográfica padronizada das TRs, realizada com posicionador de cabeça, oferece resultados satisfatórios, fáceis na sua obtenção e de baixo custo.

Nesse trabalho foram utilizadas as imagens das ATMs obtidas com a técnica padronizada da transcraniana, e os espaços articulares foram mensurados para se avaliar a concentricidade condilar. Como afirmado anteriormente, a mensuração e determinação da concentricidade condilar não devem fazer parte da rotina clínica, seja de pacientes ortodônticos, ou mesmo de pacientes portadores de algum sinal ou sintoma de DTM. Procedimentos irreversíveis para correção de eventuais pequenas alterações posicionais dos côndilos nas fossas não encontram suporte científico. 
Toda técnica de imagem é considerada complementar ao exame clínico, que inclui a anamnese e o exame físico, fundamentais para formulação de um diagnóstico correto e plano de tratamento adequado. A presença de "achatamento" condilar em pacientes assintomáticos ilustra a condição acima, não havendo necessidade de intervenção na ausência de sintomas.

Considerando toda a amostra, as médias do espaço articular anterior foram: do lado direito $1,7 \mathrm{~mm}$ e lado esquerdo $1,8 \mathrm{~mm}$, sendo os respectivos valores para o espaço articular posterior direito de 2,3mm e 2,1 $\mathrm{mm}$ para o esquerdo. Esses valores foram similares aos de ISMAIL; $\mathrm{ROKN}^{52}$ ao comparar os espaços articulares mensurados em posições de $\mathrm{RC}$ e MIH, em pacientes Classe I, assintomáticos. Esses autores obtiveram para os espaços articulares anterior $2,1 \mathrm{~mm}$ bilateralmente, para o posterior lado direito $2,1 \mathrm{~mm}$ e esquerdo $2,3 \mathrm{~mm}$.

PEREIRA ${ }^{88}$, estudando os espaços articulares por meio de tomografias em jovens entre 12 e 18 anos, obteve como resultados para o grupo assintomático os valores do espaço articular anterior direito $1,9 \mathrm{~mm}$ e esquerdo $1,6 \mathrm{~mm}$, espaço articular posterior direito $3,7 \mathrm{~mm}$ e esquerdo $3,2 \mathrm{~mm}$. Esses valores para o grupo com disfunção foram de: $2,2 \mathrm{~mm}$ para espaço anterior direito; $1,8 \mathrm{~mm}$ para o anterior esquerdo; $3,1 \mathrm{~mm}$ para o espaço posterior direito e $3,0 \mathrm{~mm}$ para o esquerdo. Podemos observar um ligeiro aumento nesses valores quando comparados aos valores do presente trabalho. O recurso de imagem utilizado, no entanto, foi diferente, e as tomografias foram realizadas com os jovens em posição de repouso, o que, provavelmente, poderia ter levado a essa diferença. Vale ressaltar que, mesmo utilizando técnica radiográfica diferente daquela aplicada nesse estudo, também não se encontrou qualquer correlação entre a posição condilar e a presença de DTM.

Os valores dos espaços articulares também foram considerados nos três grupos, isoladamente. Esses valores médios para o grupo I foram de $1,8 \mathrm{~mm}$ e $1,9 \mathrm{~mm}$ para os espaços anterior (A) e 
posterior $(P)$, respectivamente; para o grupo II 1,8mm para $(A)$ e 2,4mm para $(P)$, sendo esses valores de $1,8 \mathrm{~mm}$ e $2,2 \mathrm{~mm}$ para $(A)$ e $(P)$ no grupo III. Ao analisar esses dados observa-se um aumento do espaço posterior nos grupos II e III, que são os grupos em tratamento e tratados com avanço mandibular, indicando um posicionamento mais anteriorizado do côndilo, mesmo com os valores semelhantes do espaço anterior. Talvez a similaridade nas médias dos espaços anteriores entre os grupos ocorra em conseqüência de uma reabsorção da parede posterior da eminência articular em decorrência ao deslocamento anterior da mandíbula.

O espaço articular superior também foi mensurado nos três grupos para as ATMs direita e esquerda e, de acordo com os valores médios para o lado direito (grupos I, II e III de 2,4mm; 2,7mm e 2,4mm, respectivamente) e para o lado esquerdo (de $2,5 \mathrm{~mm} ; 2,7 \mathrm{~mm}$ e $2,4 \mathrm{~mm}$ para os grupos I, II e III), pode-se notar um aumento discreto para o grupo II quando comparado aos grupos I e III. Na protrusão mandibular os côndilos não só se deslocam para anterior, mas para inferior também, podendo ter contribuído para esse ligeiro aumento no espaço superior do grupo II. Entretanto, essa diferença não foi estatisticamente significante.

Valores maiores para o espaço articular superior foram citados por PEREIRA ${ }^{88}$. Em contrapartida, ISMAIL; ROKNI ${ }^{52}$ obtiveram valores de $3,0 \mathrm{~mm}$ e $2,8 \mathrm{~mm}$ para os lados esquerdo e direito do espaço articular superior, achados semelhantes aos do presente trabalho utilizando a mesma técnica radiográfica.

A posição condilar pode ser inferida baseada nos valores desses espaços articulares que separam os limites do côndilo e da fossa mandibular. Todavia, para facilitar a determinação da concentricidade condilar, uma fórmula proposta por PULLINGER; HOLLENDER ${ }^{94}$ foi empregada.

Quando as médias percentuais da concentridade condilar entre os grupos foi comparada, constatou-se uma diferença estatisticamente 
significativa do grupo II para o grupo I, ou seja, os indivíduos do grupo II apresentavam os valores de menor concentricidade ( côndilos mais anteriorizados) em relação aos indivíduos do grupo I.

$\mathrm{Na}$ comparação da concentricidade condilar entre os grupos para as ATMs direita e esquerda, isoladamente, diferenças estatísticas foram detectadas apenas para o lado direito.

Apesar do grupo II apresentar um número menor de côndilos concêntricos, essa ausência de concentricidade ocorreu devido a um posicionamento mais anteriorizado dos côndilos, que, além de citado como característica dos pacientes com má oclusão de Classe II, divisão 1, tanto radiograficamente $^{98}$, como por meio de ressonância magnética ${ }^{104}$, essa posição anteriorizada talvez não prejudique o relacionamento côndilo-discofossa. Um posicionamento mais posteriorizado dos côndilos tem sido apontado como risco para desencadear problemas de desarranjo interno, pois nesses casos o disco pode se deslocar de seu assentamento sobre os côndilos e desencadear os quadros de deslocamento de disco para anterior com ou sem redução.

Com os côndilos anteriorizados, há um movimento natural do disco articular, acompanhando essa anteriorização. Esse fato leva, invariavelmente, a um estiramento de fibras colágenas e elásticas dos tecidos retrodiscais. Esse alongamento ligamentar, associado a alterações na forma do disco, tem sido relacionado a eventos de deslocamento do disco articular, podendo, em alguns casos, levar à dor e disfunção da ATM. No presente trabalho, todavia, tal fato não foi confirmado, visto que não houve presença significante de dor e ruídos articulares nos grupos em tratamento ou já tratados. O fato da amostra ter utilizado aparelho protrusivo removível também pode ter contribuído para não promover tais eventos.

Paradoxalmente, a protrusão mandibular também tem sido utilizada como terapia em casos de deslocamento de disco articular sintomáticos. Recaptura desse disco e alívio da pressão condilar nas 
estruturas retrodiscais têm sido citados como responsáveis pela melhora relatada pelos pacientes. No presente trabalho, apesar de não havermos realizado exames de ressonância magnética, casos de deslocamento de disco podem ter se beneficiado da protrusão ortopédica.

Um posicionamento mais anteriorizado dos côndilos também foi citado por RUF; PANCHERZ ${ }^{104}$ em amostras de pacientes Classe II tratados com o aparelho de Herbst e em outro estudo ${ }^{105}$ com pacientes tratados com o ativador. Nos dois estudos, o método de avaliação da posição condilar foi por meio de imagens de ressonância magnética. Essa tendência de anteriorização condilar foi detectada na remoção do aparelho, mas não se manteve quando os pacientes foram avaliados um ano após a finalização do tratamento. Já a posição condilar, analisada antes e após o tratamento no estudo do ativador, manteve-se dentro dos níveis fisiológicos, apesar de uma tendência à anteriorização condilar prévia ao tratamento. Essa tendência também foi observada no presente estudo. Ou seja, os pacientes Classe II já apresentam, naturalmente, os côndilos anteriorizados. Há uma exacerbação óbvia dessa posição durante o tratamento, com um retorno gradual à posição original, porém parece que esses côndilos mantêm-se anteriorizados mesmo após a remoção do aparelho (grupo III). O tempo após a remoção do aparelho poderia ser um fator decisivo para essas observações. Há uma preocupação óbvia da classe ortodôntica em relação à estabilidade a longo prazo desses tratamentos ortopédicos. Independente do tempo passado após a remoção do aparelho protrusivo, a utilização de aparelho fixo e a obtenção de uma intercuspidação mais efetiva (grupo III apresentou quantidade significante maior de contatos oclusais em $\mathrm{MIH}$ ) parecem ser responsáveis, associados a uma adaptação muscular, à estabilidade do caso. Os autores ainda constataram grande variabilidade do posicionamento condilar nesse estudo, fato esse em concordância com a literatura em amostras de pacientes assintomáticos ${ }^{3,96}$. 
WATTED; WITT; KENN ${ }^{132}$, avaliando a posição condilar em pacientes tratados com o Bionator, não relataram uma diferença na concentricidade condilar e na morfologia dos côndilos após o tratamento.

Quando comparando a posição condilar em amostras de indivíduos com e sem disfunção, PULLINGER et al. ${ }^{98}$ encontraram maior freqüência de concentricidade no grupo assintomático, sendo que o grupo com disfunção, independente da categoria diagnóstica, apresentou uma média de côndilos mais posteriorizados. Em contraste com esse trabalho, MIKHAIL; ROSEN ${ }^{74}$ não encontraram diferença quanto à concentricidade condilar, comparando pacientes com disfunção, uma amostra aleatória e pacientes submetidos a terapias oclusais.

Devido à grande variabilidade individual na posição condilar e à presença de côndilos não concêntricos em pessoas assintomáticas ${ }^{96}$, a relação entre saúde das ATMs e concentricidade condilar não pode ser confirmada. Qualquer forma de tratamento no sentido de restabelecer a posição condilar para tratar ou prevenir DTM também não se justifica.

No presente trabalho, em que a concentricidade condilar foi relacionada à prevalência de DTM, não foi possível se estabelecer uma associação entre essas variáveis, como podemos observar na figura 5.17. Isso significa que, mesmo diante de diferenças na posição condilar entre os grupos estudados, essa excentricidade condilar não aumentou as chances dos jovens em tratamento com o Bionator apresentarem sinais e sintomas de DTM.

Mesmo que a concentricidade condilar fosse tão importante na etiologia das DTM, a anteriorização condilar causada pelos aparelhos de avanço mandibular não seria tão danosa às ATMs uma vez que, como afirmado anteriormente, eventuais discos deslocados poderiam beneficiar-se dessa manobra. 
Nesse contexto, quando o deslocamento de disco para anterior for acompanhado de sintomatologia dolorosa, um posicionamento mais para anterior do côndilo poderá ser benéfico no sentido de melhorar os sintomas e a relação côndilo-disco. Com base nessa hipótese, talvez se justifique o fato de muitos trabalhos ${ }^{14,34,82,139}$, até mesmo indicarem o tratamento com aparelhos ortopédicos para pacientes com DTM, porém a estabilidade da recaptura permanente do disco articular ainda carece de comprovação científica.

Baseado no acima exposto, não se pode considerar a protrusão mandibular ortopédica e a conseqüente alteração da posição condilar como fatores de risco para as DTMs. Tais afirmações devem, no entanto, ser interpretadas com cautela, devido ao caráter cíclico e autolimitante de doenças de etiologia multifatorial como as DTMs. 
7- Conclusões 


\section{7- CONCLUSÕES}

7.1. Não houve diferenças na prevalência de sinais e sintomas de DTM entre os pacientes de Classe II antes, durante ou após a terapia com o Bionator;

7.2. Os fatores oclusais não se relacionaram com os índices de DTM;

7.3. Os côndilos apresentaram-se significantemente mais anteriorizados no grupo em tratamento, quando comparados ao grupo pré-tratamento;

7.4. Houve um aumento no espaço articular posterior nos grupos em tratamento ou já tratados;

7.5. Não houve relação entre concentricidade condilar e sinais e sintomas de DTM. 
Referências Bibliográficas 


\section{REFERÊNCIAS BIBLIOGRÁFICAS*}

1- AGERBERG, G.; CARLSSON, G.E. Functional disorders of the masticatory system. I- Distribution of symptoms according to age and sex as judged from investigation by questionnaire. Acta odont. scand., v.30, n.6, p.597-613, Sep. 1972.

2- AGERBERG, G.; CARLSSON, G.E. Functional disorders of the masticatory system. II- Symptoms in relation to impaired mobility of the mandible as judged from investigation by questionnaire. Acta odont. scand., v.31, n.6, p.335-47, July 1973.

3- ALEXANDER, S.R.; MOORE, R.N.; DuBOIS, L.M. Mandibular condyle position: Comparison of articular mountings and magnetic resonance imaging. Amer. J. Orthodont. Dentofac. Orthop., v.104, n.9, p.230-9, Sep. 1993.

4- ARTUN, J.; HOLLENDER, L.G.; TRUELOVE, E.L. Relationship between orthodontic treatment, condylar position, and internal derangement in the temporomandibular joint. Amer. J. Orthodont. Dentofac. Orthop., v.101, n.1, p.48-53, Jan. 1992.

5- AUSTIN, D.G.; PERTES, R.A. Examination of the TMD patient. In: PERTES, R.A.; GROSS, S.G. Clinical management of temporomandibular disorders and orofacial pain., Chicago, Quintessence, 1995. Cap.9 p.123-60.

6- BAKER, R.W.; CATANIA, J.A.; BAKER JUNIOR, R.W. Occlusion as it relates to TMJ. A study of the literature. N.Y. St. dent. J., v.57, n.1, p.36-9, Jan. 1991.

7- BIRKEBAEK, L.; MELSEN, B.; TERP, S. A laminografhic study of the alterations in the temporomandibular joint following activator treatment. Europ. J. Orthodont., v.6, p.257-66, Nov. 1984.

\footnotetext{
* Normas recomendadas para uso no âmbito da Universidade de São Paulo, com base no documento "Referências Bibliográficas: exemplos", emanado do Conselho Supervisor do Sistema Integrado de Bibliotecas da USP, em reunião de 20 de setembro de 1990.
} 
8- BONILLA-ARAGON, $\mathrm{H}$. et al. Condyle position as a predictor of temporomandibular joint internal derangement. J. prosth. Dent., v.82, n.2, p.205-8, 1999.

9- BOSCOLO, F.N.; ALMEIDA, S.M.; PAGANINI, G.A. Estudo da imagem da ATM por duas técnicas radiográficas. RGO, v.46, n.4, p.222-9, 1998.

10- CARLTON, K.L.; NANDA, R.S. Prospective study of posttreatment changes in the temporomandibular joint. Amer. J. Orthodont. Dentofac. Orthop., v.122, n.5, p. 486-90, Nov. 2002.

11- CARWELL, M.L.; McFALL JR., W.T. Centric relation determinations: Clinical and radiographic comparisons. J. Periodont. v.52, n.7, p.347-53, July 1981.

12- CELIC, R.; JEROLIMOV, V.; PANDURIC, J. A study of the influence of occlusal factors and parafunctional habits on the prevalence of signs and symptoms of TMJ. Int. J. Prosthodont., v.15, n.1, p.438,2002 .

13- CLARK, G.T. et al. Guidelines for the examination and diagnosis of temporomandibular disorders. J. craniomandibular dis. fac. oral pain, v.3, n.1, p.4-7, winter, 1989.

14- CLARK, W.J.; GRABER, T.M. Twin block functional therapy: applications in dentofacial orthopedics. Turin, Mosby-Wolfe, cap.3, 1995.

15- COHLMIA, J.T. et al. Tomographic assessment of temporomandibular joints in patients with malocclusion. Angle Orthodont., v.66, n.1, p.27-35, 1996.

16- CONTI, A.C.C.F et al. Relationship between signs and symptoms of Temporomandibular Disorders and orthodontic treatment: A crosssectional study. Angle Orthodont., v.73, n.4, 2003. 
17- CONTI, P.C.R.; SANTOS, C.N.; LAURIS, J.R.P. Interexaminer agreement for muscle palpation procedures: the efficacy of a calibration program. Cranio, v.20, n.4, p.289-94, Oct. 2002.

18- CONTI, P.C.R. et al. A cross-sectional study of prevalence and etiology of signs and symptoms of temporomandibular disorders in high school and university students. J. Orofac. pain, v.10, n.3, p. 25462, 1996.

19- CONTI, P.C.R. Low level laser therapy in the treatment of Temporomandibular Disorders: a double-blind pilot student. J. Craniomandibular Pract., v. 15, n. 12, p. 144-49, 1997.

20- COSTEN, J.B. A syndrome of ear sinus symptoms dependent upon disturbed functions of TMJ. Ann. Otol. (St. Louis), v.43, n.1, p.1-15, Mar. 1934.

21- COSTEN, J.B. Neuralgias and ear symptoms associated with disturbed function of the TMJ. J. Amer. med. Ass., v.107, p.252-4, 1936.

22- DAHL, B.L. et al. Signs and symptoms of craniomandibular disorders in two groups of 19-year-old individuals, one treated orthodontycally and the other not. Acta odont. scand., v.46, n.2, p.89-93, Apr. 1988.

23- DIBBETS, J.M.H.; VAN DER WEELE, L.TH. Orthodontic treatment in relation to symptoms attributed to dysfunction of the temporomandibular joint. Amer. J. Orthodont., v.91, p.139-99, 1987.

24- DIBBETS, J.M.H.; VAN DER WEELE, L.TH. Extraction, orthodontic treatment and craniomandibular dysfunction. Amer. J. Orthodont. Dentofac. Orthop., v.99, p.210-9, 1991.

25- DIBBETS, J.M.H.; VAN DER WEELE, L.TH. Long-term effect of orthodontic treatment, including extraction, on signs and symptoms attributed to CMD. Europ. J. Orthodont., v.14, n.1, p.16-20, Feb. 1992. 
26- DIBBETS, J.M.H.; VAN DER WEELE, L.TH. Signs and symptoms of tempromandibular disorders (TMD) and craniofacial form. Amer. J. Orthodont. Dentofac. Orthop., v.110, n.1, p.73-8, July 1996.

27- DWORKIN, S.F. et al. Epidemiology of signs and symptoms in temporomandibular disorders: clinical signs in cases and controls. J. Amer. Dent. Ass., v.120, n.3, p.273-81, Mar. 1990.

28- EKBERG, E.; SABET, M.E.; PETERSSON, A.; NILNER, M. Occlusal appliance theraphy in a short-term pespective in patients with temporomandilbular disorders correlated to condyle position. Int. J. Prosthodont., v.11, n.3, p.263-8, 1998.

29- FONSÊCA, D.M. Disfunção Craniomandibular (DCM) - diagnóstico pela anamnese. Bauru, 1992. 116p. Dissertação (Mestrado) Faculdade de Odontologia de Bauru, Universidade de São Paulo.

30- FREITAS, M.R. et al. Bionator e as Desordens Temporomandibulares (DTM): Mito ou realidade? Rev. Dental Press Ortodon. Ortop. Facial, v.5, n.5, p.80-84, set./out. 2000.

31- FUENTES, M.A. et al. Lateral functional shift of the mandible: Part I. Effects on condylar cartilage thickness and proliferation. Amer. J. Orthodont. Dentofac. Orthop., v.123, n.2, p.153-9, Feb. 2003.

32- GIANELLY, A.A. Orthodontics, condylar position, and TMJ status. Amer. J. Orthodont. Dentofac. Orthop., v.95, n.6, p.521-3, June 1989.

33- GIANELLY, A.A.; ANDERSON, C.K.; BOFFA, J. Longitudinal evaluation of condylar position in extraction and nonextraction treatment. Amer. J. Orthodont. Dentofac. Orthop., v.100, n.5, p.416-20, Nov. 1991.

34- GRABER, T.M.; NEWMANN, B. Aparelhos ortodônticos removíveis. São Paulo, Panamericana, cap.12, 2 ed. 1987. 
35- GRIFFITHS, R.H. Report of the president's conference on examination, diagnosis and management of temporomandibular disorders. J. Amer. Dent. Ass., v.107, n.6, p.932-6, Dec. 1983.

36- GROSS, M. The effect of increasing occlusal vertical dimension on transcranial radiographic projections of the temporomandibular joints. J. prosth. Dent., v.60, n.4, p.491-9, Oct.1988.

37- HANSSON, L.G; HANSSON, T.; PETERSSON, A. A comparisom between clinical and radiologic findings in 259 temporomandibular joint patients. J. prosth. Dent., v. 50, n.1, p.89-94, July 1983.

38- HELKIMO, M. Studies on function and dysfunction of the masticatory system. I- An epidemiological investigation of symptoms of dysfunction in lapps in north of Finland. Proc. Fin. dent. Soc., v.70, n.4, p.37-49, Apr. 1974.

39- HELKIMO, M. Index for anamnestic and clinical dysfunction and occlusal state. Proc. Fin. dent. Soc., v.70, n.4, p.101-21, Apr. 1974.

40- HELKIMO, M. Studies on function and dysfunction of the masticatory system. III- Analysis anamnetic and clinical recordings of dysfunction with the aid of index. Swed. dent. J., v.67, n.3, p.1582, Mar. 1974.

41- HELKIMO, M. Studies on function and dysfunction of the masticatory system. IV- Age and sex distribution of symptoms of dysfunction of the masticatory system in lapps in the north of Finland. Acta odont. scand., v.32, n.4, p.255-67, 1974.

42- HELKIMO, M. Epidemiological surveys of dysfunction of the masticatory system. Oral Sci. Rev., v.7, p.54-69, 1976.

43- HELLSING, G.; ISBERG-HOLM, A.; MCWILLIAM, J. A comparative study of two techniques for recording centric relation. Dentomaxillofac. Radiol., v.12, n.1, p.5-12, 1983. 
44- HENRIKSON, T.; NILNER, M. Temporomandibular disorders and need of stomatognathic treatment in orthodontically treated and untreated girls. Europ. J. Orthodont., v.22, n.3, p.283-92, June 2000.

45- HENRIKSON, T.; EKBERG, E.C.; NILNER, M. Symptoms and signs of temporomandibular disorders in girls with normal occlusion and Class II malocclusion. Acta odont. scand., v.55, p.229-35, 1997.

46- HENRIKSON, T.; NILNER, M.; KUROL, J. Signs of temporomandibular disorders in girls receiving orthodontic treatment. A prospective and longitudinal comparisons with untreated Class II malocclusion and normal occlusion subjects. Europ. J. Orthodont. v.22, n.3, p.27181, June, 2000.

47- HENRIKSON, T.; NILNER, M.; KUROL, J. Symptoms and signs of temporomandibular disorders before, during and after orthodontic treatment. Swed. dent. J. v.23, n. 5-6, pg.193-207, 1999.

48- HIYAMA, S. et al. Nocturnal masseter and suprahyoid muscle activity induced by wearing a bionator. Angle Orthodont., v.72, n.1, p.48$54,2002$.

49- HIYAMA, S. et al. Neuromuscular and skeletal adaptations following mandibular forward positioning induced by the herbst appliance. Angle Orthodont., v.70, n.6, p.442-53, 2000.

50- ILLICH, I. Medical Nemesis. New York, Phantom, p. 15, 1976.

51- INGERVALL, B.; CARLSSON, G.E. Masticatory muscle activity before elimination of balancing side occlusal interference. J. oral Rehab., v.9, n.3, p.183-92, May 1982.

52- ISMAIL, Y.H.; ROKNI, A. Radiographic study of condylar position in centric relation and centric occlusion. J. prosth. Dent., v 43,n.3, p.328-30, Mar. 1980.

53- JANSON, M.; HASUND, A. Functional problems in orthodontic patients out of retention. Europ. J. Orthodont., v.3, p.173-9, 1981. 
54- KATZBERG, R.W. et al. Orthodontics and temporomandibular joint internal derangement. Amer. J. Orthodont. Dentofac. Orthop., v.109, n.5, p.515-20, May 1996.

55- KEELING, S.D. et al. Risk factors associated with temporomandibular joint sounds in children 6 to 12 years of age. Amer. J. Orthodont. Dentofac. Orthop., v.105, n.3, p.279-87, Mar. 1994.

56- KEELING, S.D. et al. Disfunções temporomandibulares após tratamento precoce de Classe II com bionator e aparelhos extrabucais: resultados de um teste randomizado controlado. Semin. Orthodont., p.139-52.

57- KIM, M.R.; GRABER, T.M.; VIANA, M.A. Orthodontics and temporomandibular disorders: A meta-analysis. Amer. J. Orthodont. Dentofac. Orthop., v.121, n.5, p.438-46, Maio 2002.

58- KORIOTH, T.W.P. Física simulada da mandíbula humana. In: MC NEILL, C. Ciência e Prática da Oclusão. São Paulo, Quintessence, 2000.

59- KUNDERT, M. Limits of perceptibility of condyle displacements on temporomandibular joint radiographs. J. oral Rehab., v.6, n.4, p.375-83, Oct. 1979.

60- KUNDINGER, K.K. et al. An evaluation of temporomandibular joints and jaw muscles after orthodontic treatment involving premolar extractions. Amer. J. Orthodont. Dentofac. Orthop., v.100, n.2, p.110-5, Aug. 1991

61- LAGERSTRÖM, L.; EGERMARK, I.; CARLSSON, G.E. Signs and Symptoms of temporomandibular disorders in 19-year-old individuals who have undergone orthodontic treatment. Swed. dent. J., v.22, n.56, p.177-86, 1998.

62- LASKIN, D.M. Etiology of the pain-dysfunction syndrome. J. Amer. dent. Ass., v.79, n.6, p.147-53, July 1969. 
63- LIEDBERG, J.; ROHLIN, M.;, PER-LENNART W. Observer perfomance in assessment of condylar position in temporomandibular joint radiograms. Acta odont. Scand., v.43, n.1, p.53-8, Mar. 1985.

64- LUECKE, P.E.; JOHNSTON JUNIOR, L.E. The effect of maxillary first premolar extraction and incisor retraction on mandibular position: Testing the central dogma of "functional orthodontics". Amer. J. Orthodont. Dentofac. Orthop., v.101, n.1, p.4-12, Jan. 1992.

65- MAJOR, P. et al. Condyle displacement associated with premolar extraction and nonextraction orthodontic treatment of Class I malocclusion. Amer. J. Orthodont. Dentofac. Orthop., v.112, n.4, p.435-40, Oct. 1997.

66- MAJOR, P.W. et al. Tomographic assessment of temporomandibular joint osseous articular surface contour and spatial relationships associated with disc displacement and disc length. Amer. J. Orthodont. Dentofac. Orthop., v.121, n.2, p.152-61,Feb. 2002.

67- MAMANDRAS, A.H,; ALLEN, L.P. Mandibular response to orthodontic treatment with the Bionator appliance. Amer. J. Orthodont. Dentofac. Orthop., v.97, n.2, p.113-20, 1990.

68- MCNAMARA JUNIOR, J.A.; BRYAN, F.A. Long-term mandibular adaptations to protrusive function: An experimental study in Macaca Mulata. Amer. J. Orthodont. Dentofac. Orthop., v.92, n.2, p.98108, 1987.

69- MCNAMARA JUNIOR, J.A.; CARLSON, D.S. Quantitative analysis of temporomandibular joint adaptations to protrusive function. Amer. J. Orthodont., v.76, n.6, p.593-611, 1979.

70- MCNAMARA JUNIOR, J.A.; TÜRP, J.C. Orthodontic treatment and temporomandibular disorders: is there a relationship? Part 1: Clinical studies. J. Orofac. Orthop., v.58, n.2, p.74-89, 1997. 
71- MCNAMARA JUNIOR, J.A.; HINTON, R.J.; HOFFMAN, D.L. Histologic analysis of temporomandibular joint adaptation to protrusive function in young adult rhesus monkey. Amer. J. Orthodont., v.82, n.4, p.288-98, 1982.

72- MCNAMARA JUNIOR, J.A.; SELIGMAN, D.A.; OKESON, J.P. Occlusion, orthodontic treatment, and temporomandibular disorders: A review. J Orofac. pain, v.9, n.1 ,p.73-90, 1995.

73- MONGINI, F. The importance of radiography in the diagnosis of TMJ dysfunctions. J. prosth. Dent., v.45, n.2, p.186-98, Feb. 1981.

74- MIKHAIL, M.G.; ROSEN, H. The validity of temporomandibular joint radiographs using the head positioner. J. prosth. Dent., v.42, n.4, p.441-6, Oct. 1979.

75- MYERS, D.R. et al. Condylar position in children with functional posterior crossbites: before and after crossbite correction. Pediat. Dent., v.2, n.3, p.190-4, 1980.

76- MUTO, T. et al. The position of the mandibular condyle at maximal mouth opening in normal subjects. J. oral Maxillofac. Surg. v.52, n.12, p.1269-72, Dec. 1994.

77- NIELSEN, L.; MELSEN, B.; TERP, S. Prevalence, interrelation, and severity of signs of dysfunction from masticatory system in 14-16year-old danish children. Community Dent. oral Epidem., v.17, p.91-6, 1989.

78- NIELSEN, L.; MELSEN, B.; TERP, S. TMJ function and the effects on the masticatory system on 14-16-year-old Danish children in relation to orthodontic treatment. Europ. J. Orthodont., v.12, n.3, p. 25462, Aug. 1990.

79- OKESON, J.P. Orofacial Pain. Guidelines for assessment, diagnosis and management. Chicago, Quintessence, 1996. 
80- OP HEIJ, D.G.; CALLAERT, H.; OPDEBEECK, H.M. The effect of the amount of protrusion built into the Bionator on condylar growth and displacement: A clinical study. Amer. J. Orthodont. Dentofac. Orthop., v.95, n.5, p.401-9, 1989.

81- OZAWA, S. et al. Reconsideration of the TMJ condylar position during internal derangement: comparison between condylar position on tomogram and degree of disk displacement on MRI. Cranio, v.17, n.2, p.93-100, 1999.

82- OWEN, A.H. Orthopedic/orthodontic treatment of craniomandibular pain dysfunction. Part B: Treatment flow. Sheet, anterior disk displacement, and case histories. J. Craniomandibular Pract., v.6, n.1, p.48-63, Jan. 1988.

83- OWEN, A.H. Unexpected temporomandibular joint findings during fixed appliance therapy. Amer. J. Orthodont. Dentofac. Orthop., v.113, n.6, p.625-31, June 1998.

84- PANCHERZ, H. The Herbst appliance- its biologic effect and clinical use. Amer. J. Orthodont., v.87, p.1-20, 1985.

85- PANCHERZ, H.; RUF, S.; THOMALSKE-FAUBERT, C. Mandibular articular disk position changes during Herbst treatment: A prospective longitudinal MRI study. Amer. J. Orthodont. Dentofac. Orthop., v.116, n.2, p.207-14, Aug. 1999.

86- PELTOLA, J.S.; KÖNÖNEN, M.; NYSTRÖM, M. A follow-up study of radiographic findings in the mandibular condyles of orthodontically treated patients and associations with TMD. J. dent. Res., v.74, n.9, p.1571-6, Sept. 1995.

87- PELTOLA, J.S. et al. Radiographic findings in the mandibular condyles of young individuals receiving orthodontic treatment. Acta odont. scand., v.53, n.2, p.85-91, Apr. 1995. 
88- PEREIRA, L.J. Avaliação ultra-sonográfica e tomográfica da articulação temporomandibular em adolescentes. Piracicaba, 2003. 101p. Dissertação (Mestrado)- Faculdade de Odontologia de Piracicaba, Universidade Estadual de Campinas.

89- PETRIKOWSKI, C.G.; GRACE, M.G.A. Age and gender differences in temporomandibular joint radiographic findings before orthodontic treatment in adolescents. Oral Surg., v.87, n.3, p.380-5, Mar. 1999.

90- PORTO, V.C. Avaliação da posição condilar em pacientes desdentados totais portadores de dentaduras duplas, através de planigrafias da ATM. Bauru, 2000. 90p. Dissertação (Mestrado) - Faculdade de Odontologia de Bauru, Universidade de São Paulo.

91- PRENTISS, H. A preliminary report upon the temporomandibular articulation in the human type. Dent. Cosmos, v.60, n.6, p.505-12, June 1918.

92- PRETI, G.; FAVA., C. Lateral transcranial radiography of temporomandibular joints. Part I: Validity in skulls and patients. J. prosth. Dent., v. 59, n.1, p.85-93, Jan., 1988.

93- PULLINGER, A.; HOLLENDER, L. Assessmennt of mandibular condyle position: A comparison of transcranial radiographs and linear tomograms. Oral Surg., v.60, n.3, p.329-34, Sep. 1985.

94- PULLINGER, A.; HOLLENDER, L. Variation in condyle-fossa relationships according to different methods of evaluation in tomograms. Oral Surg., v.62, p.719-27, 1986.

95- PULLINGER. A.G.; SELIGMAN, D.A. Overbite and overjet characteristics of refined diagnostic groups of temporomandibular disorders patients. Amer. J. Orthodont. Dentofac. Orthop., v.100, n.5, p.401-15, 1991. 
96- PULLINGER, A.G. et al. A tomografic study of mandibular condyle position in an asymptomatic population. J. prosth. Dent., v.53, n.5, p.706-13, May 1985.

97- PULLINGER, A.G. et al. Tomographic analysis of mandibular condyle position in diagnostic subgroups of temporomandibular disorders. J. prosth. Dent., v.55, n.6, p.723-9, June 1986.

98- PULLINGER, A.G. et al. Relationship of mandibular condylar position to dental occlusion factors in an asymptomatic population. Amer. J. Orthodont. Dentofac. Orthop., v.91, n.3, p.200-6, Mar. 1987.

99- RABIE, A.B.M. et al. Osteogenesis in the glenoid fossa in response to mandibular advancement. Amer. J. Orthodont. Dentofac. Orthop., v.119, n.4, p.390-400, Apr. 2001.

100- REN, Y.F.; ISBERG, A.; WESTESSON, P. L. Condyle position in the temporomandibular joint. Comparison between asymptomatic volunteers with normal disk position and patients with disk displacement. Oral Surg., v.80, n.1, p.101-7, 1995.

101- REYNDERS, R.M. Orthodontics and temporomandibular disorders: A review of literature (1966-1988). Amer. J. Orthodont. Dentofac. Orthop., v.97, n.6, p.463-71, June 1990.

102- RINCHUSE, D.J. Counterpoint: Preventing adverse effects on the temporomandibular joint through orthodontic treatment. Amer. J. Orthodont. Dentofac. Orthop., v.91, n.6, p.500-6, June 1987.

103- RONQUILLO, H.I. et al. Comparison of internal derangements with condyle-fossa relationships, horizontal and vertical overlap, and angle class. J. craniomandibular dis. Fac. Oral pain, v.2, n.3, p.137-40, 1988.

104- RUF, S.; PANCHERZ, H. Does bite-jumping damage the TMJ? A prospective longitudinal clinical and MRI study of Herbst patients. Angle Orthodont., v.70, n.3, p. 183-99, June 2000. 
105- RUF, S.; WÜSTEN, B.; PANCHERZ, H. Temporomandibular joint effects of activator treatment: A prospective longitudinal magnetic resonance imaging and clinical study. Angle Orthodont., v.72, n.6, p.527-40, Dec. 2002.

106- RUNGE, M.E. et al. The relationship between temporomandibular joint sounds and malocclusion. Amer. J. Orthodont. Dentofac. Orthop., v.96, n.1, p.36-42, July 1989.

107- SADOWSKY, C. The risk of orthodontic treatment for producing temporomandibular disorders: A literature review. Amer. J. Orthodont. Dentofac. Orthop., v.101, n.1, p.79-83, Jan. 1992.

108- SADOWSKY, C.; BeGOLE, E.A. Long-term status of temporomandibular joint function and functional occlusion after orthodontic treatment. Amer. J. Orthodont., v.78, n.2, p.201-12, Aug. 1980.

109- SADOWSKY, C.; POLSON, A.M. Temporomandibular disorders and functional occlusion after orthodontic treatment: Results of two longterm studies. Amer. J. Orthodont. Dentofac. Orthop., v.86, n.5, p.386-90, Nov. 1984.

110- SADOWSKY, C. et al. Temporomandibular joint sounds related to orthodontic therapy. J. dent. Res., v.64, n.12, p.1392-5, Dec. 1985.

111- SANTOS, C.N. Avaliação da eficácia de placas estabilizadoras com padrão de guia balanceada bilateral no controle dos desarranjos internos. Bauru, 2003. 116p. Dissertação (Doutorado) - Faculdade de Odontologia de Bauru, Universidade de São Paulo.

112- SANTOS, E.C.A. et al. Radiografia da articulação temporomandibular: Apresentação de um método para avaliação do espaço articular. J. Bras. Oclusão ATM e dor orofacial, v.3, n.10, p.119-23, abr/jun 2003. 
113- SCHNEIDERMAN, E.D.; CARLSON, D. Cephalometric analysis of condyle adaptations to altered mandibular position in adult Rhesus monkey, Macaca Mulata. Arch. oral Biol., v.30, p.49, 1985.

114- SCHWARTZ, L. Pain associated with the temporomandibular joint. J. Amer. dent. Ass., v.51, n.10, p.394-401, Oct. 1955.

115- SELIGMAN, D.A.; PULLINGER, A.G. The role of intercuspal occlusal relationship in temporomandibular disorders: a review. J. craniomandibular dis. fac. oral pain., v.5, n.2, p.96-106, 1991.

116- SFONDRINI, G. et al. Adaptations of masticatory muscles to a hyperpropulsive appliance in the rat. Amer. J. Orthodont. Dentofac. Orthop., v.110, n.6, p.612-7, Dec. 1996.

117- SICHER, H. Temporomandibular articulation in mandibular overclosure. J. Amer. dent. Ass., v.36, n.2, p.131-9, Feb. 1948.

118- SMITH, N.J.D.; HARRIS, M. Radiology of the temporomandibular joint and condylar head. Brit. dent. J., v.129, n.20, p.361-8, Oct. 1970.

119- SOLBERG, W.K.; WOO, M.W.; HOUSTON, J.B. Prevalence of mandibular dysfunction in young adults. J. Amer. dent. Ass., v.98, p.25-34, Jan. 1979.

120- STOCKLI, P.W. Tissue reaction in the temporomandibular joint resulting from anterior displacement of the mandible in the monkey. Amer. J. Orthodont., v.60, n.2, p.142-55, 1971.

121- TASAKI, M.M. et al. Classification and prevalence of temporomandibular joint displacement in patients and symptom-free volunteers. Amer. J. Orthodont. Dentofac. Orthop., v.109, n.3, p.249-62, Mar. 1996.

122- THOMPSON, J.R. The individuality of the patient and the temporomandibular joints. Part I. Amer. J. Orthodont. Dentofac. Orthop., v.105, n.1, p.83-7, 1994. 
123- TYNDALL, D.A. et al. Validity of digital subtraction of transcranial plain films in quantification of positional changes of the mandibular condyle. Oral Surg., v.71, n.6, p.748-55, Jan. 1991.

124- VALLE-COROTTI, K.M. et al. A oclusão e sua relação com as Disfunções Temporomandibulares (DTM) em jovens com e sem tratamento ortodôntico: um estudo comparativo. Rev. Dental Press Ortod. Ortop. Facial., v.8, n.6, p.79-87, Nov-Dez. 2003.

125- VAN SICKELS, J.E.; BIANCO JR., H.J.; PIFER, R.G. Transcranial radiographs in the evaluation of craniomandibular disorders. $\mathbf{J}$. prosth. Dent., v.49, n.2, p.244-9, Feb. 1983.

126- WADHWA, L.; UTREJA, A.; TEWARI, A. A study of clinical signs and symptoms of temporomandibular dysfunction in subjects with normal occlusion, untreated, and treated malocclusions. Amer. J. Orthodont. Dentofac. Orthop., v.103, n.1, p.54-61, Jan. 1993.

127- WÄNMAN, A.; AGERBERG, G. Mandibular dysfunction in adolescents.

I. Prevalence of symptoms. Acta odont. scand., v.44, p.47-54, 1986.

128- WÄNMAN, A.; AGERBERG, G. Mandibular dysfunction in adolescents. II. Prevalence of signs. Acta odont. scand., v.44, p.55-62, 1986.

129- WÄNMAN, A.; AGERBERG, G. Two-year longitudinal study of symptoms of mandibular dysfunction in adolescents. Acta odont. scand., v.44, p.321-31, 1986.

130- WÄNMAN, A.; AGERBERG, G. Two-year longitudinal study of signs of mandibular dysfunction in adolescents. Acta odont. scand., v.44, p.333-42, 1986.

131- WARD, D.M.; BEHRENTS, R.G.; GOLDBERG, J.S. Temporomandibular synovial fluid pressure response to altered mandibular positions. Amer. J. Orthodont. Dentofac. Orthop., v.98, n.1, p.22-8, 1990. 
132- WATTED, N.; WITT, E.; KENN, W. The temporomandibular joint and the disc-condyle relationship after functional orthopedic treatment: a magnetic resonance imaging study. Europ. J. Orthodont., v.23, p.683-93, 2001.

133- WEINBERG, L.A. Role of condylar position in TMJ dysfunctionpain syndrome. J. prosth. Dent., v. 41, n.6, p.636-43, June 1979.

134- WILKIE, N.D.; HURST, T.L.; MITCHELL, D.L. Radiographic comparisons of condyle-fossa relationships during maxillomandibular registration made by different methods. $\mathbf{J}$. prosth. Dent., v.32, n.5, p.529-33, Nov. 1974.

135- WILLIAMS, B.H. Tomographic stability of condyle fossa relationships in 40 treated tempormandibular disorderspatients. J. prosth. Dent., v.79, n.5, p.570-4, May 1998.

136- WILLIAMSON, E.H. Laminographic study of mandibular condyle position when recording centric relation. J. prosth. Dent., v. 39, n.5, p.561-4, May 1978.

137- WILLIANSON, E.H. Mandibular orthopedic change and closure of anterior open bite following reduction of disk dislocation. Amer. J. Orthodont. Dentofac. Orthop., v.3, n.7, p.3-7, 1986.

138- WILLIAMSON, E.H. The role of craniomandibular dysfunction in orthodontic diagnosis and treatment planning. Dent. Clin. N. Amer., v.27, n.3, p.541-60, July 1983.

139- WITZIG, J.W.; SPAHL, T.J. The clinical management of basic maxillofacial orthopedic appliances. Hong Kong, Year Book Medical Publisher, Inc, cap 2, 1987.

140- WYATT, W.E. Preventing adverse effects on the temporomandibular joint through orthodontic treatment. Amer. J. Orthodont. Dentofac. Orthop., v.91, n.6, p.493-9, June 1987. 
Abstract 


\section{ABSTRACT}

The aim of this study was to evaluate the possible effects of orthopedic mandibular protrusion and condyle position in the prevalence and severity of Temporomandibular Disorders (TMD). The sample was composed of 60 individuals with Angle class II malocclusion divided into three groups depending upon the accomplishment of functional orthopedic treatment (prior, during and after therapy with the bionator appliance). An anamnestic questionnaire, composed of questions regarding most frequent symptoms was used to classify the sample according to the TMD presence and severity. A clinical examination, including temporomandibular joint (TMJ) and muscle palpation, mandibular range of motion and joint noises analysis was also performed. Serial standard right and left TMJ transcranial images were taken with the teeth in intercuspal position, digitalized and condyle concentricity was determined. One-way ANOVA, Kruskal-Wallis and Chi- square accounted for data analysis. Based on the anamnestic questionnaire, 30\% was considered as having mild TMD, while $3.33 \%$ had moderate $T M D$, with no difference between groups ( $p>0.05$ ). Group II (during therapy) has shown significant anterior condyle positioning $(p<0.05)$ when compared to group I, although no association was found between this variable and TMD presence or severity $(p>0.05)$. Authors concluded that mandibular orthopedic protrusion was not a risk factor for TMD in the sample studied. 
Anexo 
Exame:

Data:

UNIVERSIDADE DE SÃO PAULO

FACULDADE DE ODONTOLOGIA DE BAURU

Nome:

Data nascimento:

Endereço: Bairro:

Cidade:

Estado:

CEP: Fone res:

Nome do responsável:

Endereço de trabalho Fone $2^{\text {ario }}$

Sexo:

Idade:

anos e meses

\section{ANAMNESE}

1. Você sente dificuldade de abrir a boca?

2. Você sente dificuldade de movimentar sua mandíbula para os lados?

3. Você sente desconforto ou dor muscular quando mastiga?

4. Você sente dores de cabeça com freqüência ?

5. Você sente dores no pescoço e/ou ombros ?

6. Você sente dores de ouvido ou próximo a ele ?

7. Você percebe algum ruído na ATM ?

8. Você considera sua mordida "normal" ?

9. Você usa apenas um lado de sua boca para mastigar?

10. Você sente dores na face ao acordar?

11. Você se considera uma pessoa tensa?

12. Você apresenta algum dos seguintes hábitos?
Ranger dentes
$\square$ Mascar chicletes
Apertar dentes
Uso contínuo de telefone
Roer unhas
Uso contínuo do computador

Revisão dos sistemas:

$\begin{array}{llllll} & \text { NEG } & \text { POS } & & \text { NEG } & \text { POS } \\ \text { Cardiovascular } & & & & & \\ \text { Gastrointestinal/Fígado } & - & - & \begin{array}{l}\text { Endócrino } \\ \text { Respiratório }\end{array} & - \\ \text { Musculoesqueletal } & - & - & \begin{array}{l}\text { Neurológico } \\ -\end{array}\end{array}$




\section{EXAME CLÍNICO}

1. AVALIAÇÃO DA ATM:

a) Movimentação

DOR

ABERTURA MÁXIMA

(incluindo trespasse)

$\mathrm{mm}$

LATERALIDADE DIREITA

$\mathrm{mm}$

LATERALIDADE ESQUERDA

$\mathrm{mm}$

PROTRUSÃO

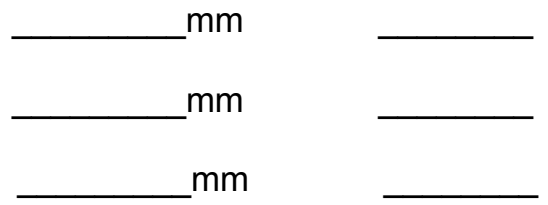

ABERTURA: $\begin{aligned} & \square \text { Simétrica } \\ & \square \text { Desvio } \\ & \square \text { Deflexão }\end{aligned}$

Direita

Esquerda

Direita

Esquerda

b) Ruídos articulares
ESTALIDO
Esquerdo
CREPITAÇÃO
Direito
Esquerdo
HIPERMOBILIDADE
Direito
Esquerdo

ERTURA

FECHAMENTO

Direito $\square$ Esquerdo

c) Palpação da ATM:

\begin{tabular}{|c|c|c|}
\hline & Direita & Esquerda \\
\hline Aspecto lateral & & \\
\hline Aspecto posterior & & \\
\hline
\end{tabular}

\section{EXAME MUSCULAR:}

Temporal

Anterior

Médio

Posterior

Masseter superficial

Origem

Corpo

Inserção
DIREITO

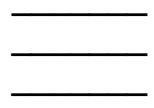

DIREITO
ESQUERDO

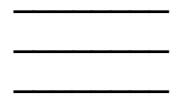

ESQUERDO 
Masseter profundo Digástrico posterior Esternocleidomastoideo Trapézio (superior)

3. AVALIAÇÃO DENTAL E OCLUSAL:

$\mathbf{X}=$ Ausente $\quad \mathbf{F}=$ Faceta de desgaste $\quad \mathbf{E}=$ Em erupção $\quad$ Es $=$ Esfoliado

\begin{tabular}{l|l|l|l|l|l|l|l|l|l|l|l|l|l|l|l}
18 & 17 & 16 & 15 & 14 & 13 & 12 & 11 & 21 & 22 & 23 & 24 & 25 & 26 & 27 & 28 \\
\hline 48 & 47 & 46 & 45 & 44 & 43 & 42 & 41 & 31 & 32 & 33 & 34 & 35 & 36 & 37 & 38
\end{tabular}

\begin{tabular}{l|l|l|l|l|l|l|l|l|l}
55 & 54 & 53 & 52 & 51 & 61 & 62 & 63 & 64 & 65 \\
\hline 85 & 84 & 83 & 82 & 81 & 71 & 72 & 73 & 74 & 75
\end{tabular}

TRESPASSE VERTICAL: $\mathrm{mm}$

TRESPASSE HORIZONTAL: $\mathrm{mm}$

Mordida aberta anterior Mordida cruzada unilateral Mordida cruzada bilateral

RelaçãoSagital

Tipo de aparelho :

Bionator

Bionator + Fixo

Herbst

Herbst + Fixo

NÚMERO DE DENTES AUSENTES: $\square 0-4 \quad \square 4-10 \quad \square+10$

RELAÇÕES MAXILOMANDIBULARES:
$\mathrm{RC}=\mathrm{MIH}$
$\mathrm{RC} \neq \mathrm{MIH}$

Discrepância vertical:
$0-2 \mathrm{~mm}$
$2-4 \mathrm{~mm}$
$>4 \mathrm{~mm}$

GUIA LATERAL DIREITA

Ausente

Guia canino

Função em grupo 
GUIA LATERAL ESQUERDA

$\square$ Ausente
$\square$ Guia canino
$\square$ Função em grupo

GUIA ANTERIOR

$\square$ Presente

Ausente

INTERFERÊNCIAS EM NÃO-TRABALHO DIREITO

$\square$ Não

$\square$ Sim $\quad \square$ Com guia $\quad \square$ Sem guia

INTERFERÊNCIAS EM NÃO-TRABALHO ESQUERDO

$\square$ Não

$\square$ Sim $\quad \square$ Com guia $\quad \square$ Sem guia

NÚMERO DE CONTATOS EM MIH:

\section{EXAME RADIOGRÁFICO}

Data do exame:

Prévio $\square$ Durante $\square$ Após

\section{ATM DIREITA}

MEDIDAS:

Anterior:

Posterior: $\mathrm{mm}$ $\mathrm{mm}$

TRANSLAÇÃO CONDILAR:

ALTERAÇÕES MORFOLÓGICAS:

$\square$ Não $\quad \square$ Moderada $\quad \square$ Severa

CONCENTRICIDADE:

\section{ATM ESQUERDA}

MEDIDAS:

Anterior:

Posterior: $\mathrm{mm}$ $\mathrm{mm}$

TRANSLAÇÃO CONDILAR:

ALTERAÇÕES MORFOLÓGICAS:

$\square$ Não $\square$ Moderada $\square$ Severa

CONCENTRICIDADE:

Concêntrico

Posterior

Anterior $x 100 \%=$

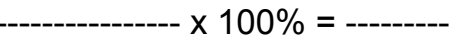

Concêntrico

$\square$ Posterior

Anterior 